Keywords: Tank Farm Characterization

Salt Dissolution Low Curie Salt

Retention: Permanent

\title{
Tanks 3F and 2F Saltcake Core and Supernate Sample Analysis
}

C. J. Martino

R. L. Nichols

D. J. McCabe

M. R. Millings

M. E. Denham

Publication date: April 13, 2004

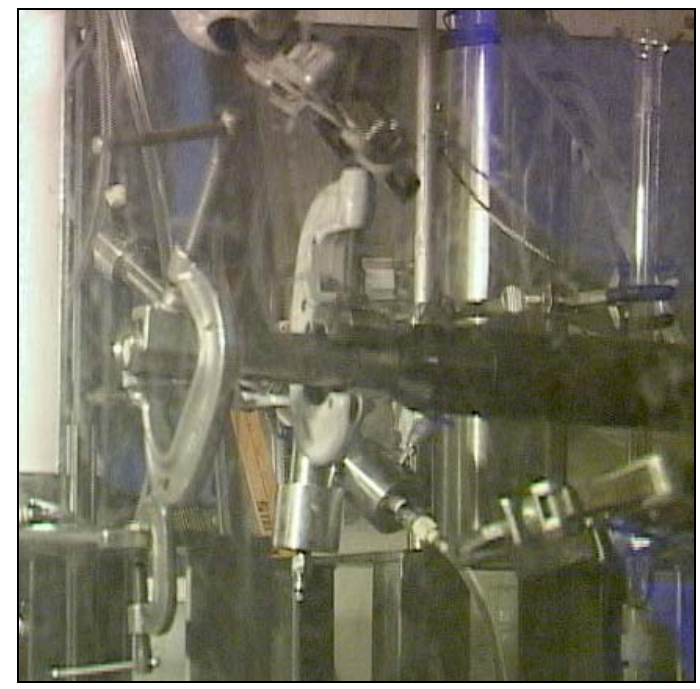

Westinghouse

Savannah River Company

Aiken, SC 29808 
This document was prepared in conjunction with work accomplished under Contract No. DE-AC09-96SR18500 with the U. S. Department of Energy.

\section{DISCLAIMER}

This report was prepared as an account of work sponsored by an agency of the United States Government. Neither the United States Government nor any agency thereof, nor any of their employees, makes any warranty, express or implied, or assumes any legal liability or responsibility for the accuracy, completeness, or usefulness of any information, apparatus, product or process disclosed, or represents that its use would not infringe privately owned rights. Reference herein to any specific commercial product, process or service by trade name, trademark, manufacturer, or otherwise does not necessarily constitute or imply its endorsement, recommendation, or favoring by the United States Government or any agency thereof. The views and opinions of authors expressed herein do not necessarily state or reflect those of the United States Government or any agency thereof.

This report has been reproduced directly from the best available copy.

Available for sale to the public, in paper, from: U.S. Department of Commerce, National Technical Information Service, 5285 Port Royal Road, Springfield, VA 22161, phone: (800) 553-6847, fax: (703) 605-6900

email: orders@ntis.fedworld.gov

online ordering: http://www.ntis.gov/help/index.asp

Available electronically at http://www.osti.gov/bridge

Available for a processing fee to U.S. Department of Energy and its contractors, in paper, from: U.S. Department of Energy, Office of Scientific and Technical Information, P.O. Box 62, Oak Ridge, TN 37831-0062,

phone: (865)576-8401,

fax: (865)576-5728

email: $\underline{\text { reports@ adonis.osti.gov }}$ 
WSRC-TR-2004-00131

Revision 0

\section{Summary}

This report provides details of the characterization of the Tank 3F saltcake samples (T3F-1-1, T3F-13 , and T3F-1-4, corresponding to FTF-223, 224, and 225, respectively) pulled in August 2003 and the Tank 2F saltcake (T2F-1-1) and supernate (FTF-245 and 246) samples pulled in August/September 2003. The saltcake samples were all collected from the surface of the saltcake layer in the tank, although for Tank $2 \mathrm{~F}$, the surface was at the bottom of a trough. The supernate samples were from the 150 inch level in Tank 2F, about 90 inches above the location of the saltcake sample. The following are the major conclusions of this analysis:

- The three Tank 3F core samples contained a total of approximately 600 grams of saltcake with a density of $2.07 \mathrm{~g} / \mathrm{cm}^{3}$ and around 170 grams of free liquid with a density of 1.47 to 1.52 $\mathrm{g} / \mathrm{cm}^{3}$. The saltcake samples differed in appearance and texture, and the as-received water contents of the samples varied from $5.1 \mathrm{wt} \%$ in T3F-1-3 to $16.8 \mathrm{wt} \%$ in T3F-1-4.

- The ${ }^{137} \mathrm{Cs}$ activities of the bottom section of undrained bulk saltcake in samples T3F-1-1 and T3F-1-4 were $1.5 \mathrm{Ci}$ and $3.5 \mathrm{Ci}$ per gallon of saltcake, respectively. This roughly corresponds to the difference in liquid content in the samples. The sum of the ${ }^{238} \mathrm{Pu},{ }^{239 / 240} \mathrm{Pu}$, and ${ }^{241} \mathrm{Am}$ activities of the bottom section of undrained bulk saltcake in samples T3F-1-1 and T3F-1-4 were $9.6 \mathrm{E}+3 \mathrm{pCi} / \mathrm{g}$ and $8.9 \mathrm{E}+3 \mathrm{pCi} / \mathrm{g}$, respectively.

- The interstitial liquid drained from sample T3F-1-4 had a density of $1.49 \mathrm{~g} / \mathrm{cm}^{3}$, a soluble solids content of $50.2 \mathrm{wt} \%$, a ${ }^{137} \mathrm{Cs}$ activity of $7.1 \mathrm{Ci} / \mathrm{gal}$., and $\mathrm{a}^{238} \mathrm{Pu},{ }^{239 / 240} \mathrm{Pu}$, and ${ }^{241} \mathrm{Am}$ activity of $1.15 \mathrm{E}+4 \mathrm{pCi} / \mathrm{mL}$. Although the ${ }^{137} \mathrm{Cs}$ activity in the interstitial liquid matched that of the free liquid samples, there were large differences in the measurement for sparingly soluble radionuclides (uranium, plutonium, americium, strontium, etc.) in these filtered liquids.

- The Tank $2 \mathrm{~F}$ core sample contained hard-packed granular saltcake with a density of 2.04 $\mathrm{g} / \mathrm{cm}^{3}$ and a water content of $6.2 \mathrm{wt} \%$. The ${ }^{137} \mathrm{Cs}$ activitiy of the undrained bulk saltcake was $0.72 \mathrm{Ci}$ per gallon of saltcake and the ${ }^{238} \mathrm{Pu},{ }^{239 / 240} \mathrm{Pu}$, and ${ }^{241} \mathrm{Am}$ activities summed to $2.1 \mathrm{E}+4$ $\mathrm{pCi} / \mathrm{g}$.

- The Tank 2F supernatant liquid samples (FTF-245 and 246), taken from a trough below riser 1 , was blue/green with only a small amount of visible insoluble solids. The supernate had a density of $1.50 \mathrm{~g} / \mathrm{cm}^{3}$, a water content of $47.8 \mathrm{wt} \%$, a ${ }^{137} \mathrm{Cs}$ activity of $6.2 \mathrm{Ci} / \mathrm{gal}$. The content of the plutonium and americium isotopes was too small to be determined.

- Salt from Tanks $2 \mathrm{~F}$ and $3 \mathrm{~F}$ were investigated by scanning electron microscopy to observe grain size, morphology, and microporosity within the saltcake grains. The light microscopy of disaggregated saltcake simulants revealed fluid inclusions.

- A flow-through dissolution test was performed on the drained saltcake sample T3F-1-4. The ${ }^{137} \mathrm{Cs}$ concentration was highest in the effluent from the earliest stages of dissolution and decreased during subsequent stages of the dissolution test. This decline in ${ }^{137} \mathrm{Cs}$ was significantly faster than the decline in sodium as the test proceeded. The bulk dissolved salt effluent had a ${ }^{137} \mathrm{Cs}$ of $0.13 \mathrm{Ci} / \mathrm{gal}$ at $3.3 \mathrm{M} \mathrm{Na}^{+}$, corresponding to $0.24 \mathrm{Ci} / \mathrm{gal}$ at $6 \mathrm{M} \mathrm{Na}^{+}$. 
This page was intentionally left blank 


\section{Table of Contents}

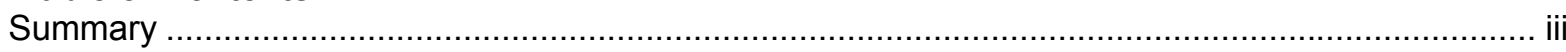

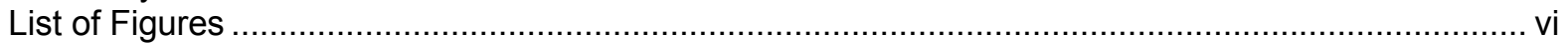

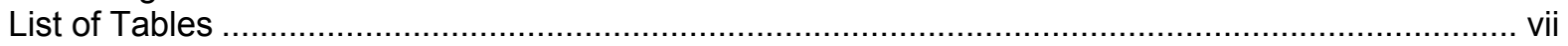

List of Abbreviations .............................................................................................................

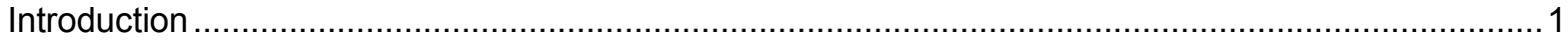

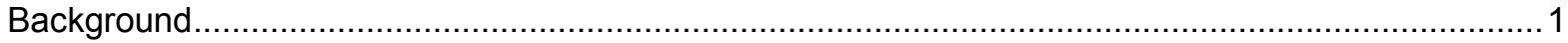

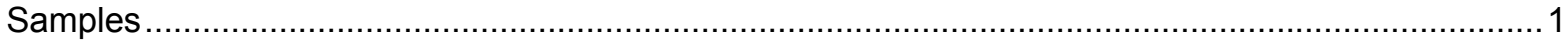

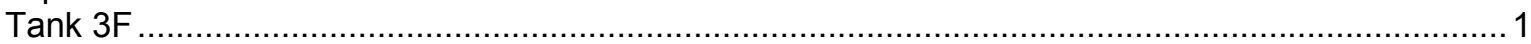

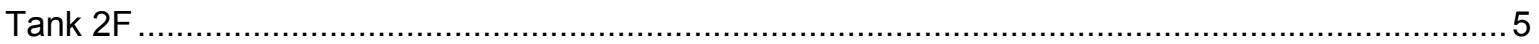

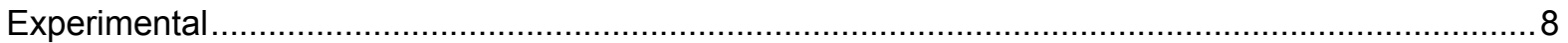

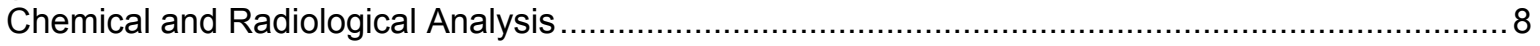

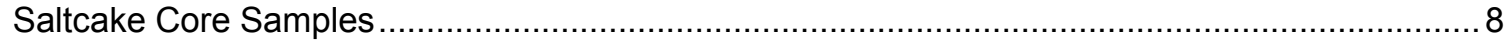

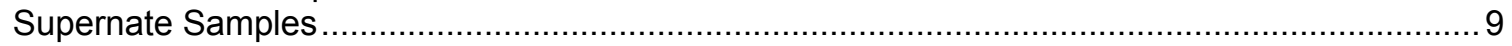

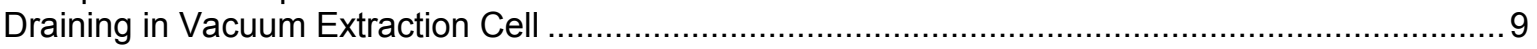

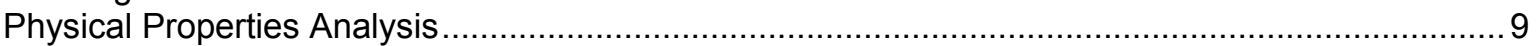

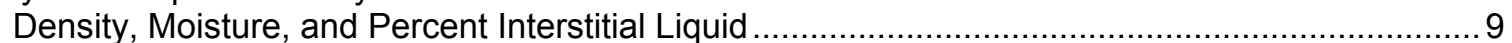

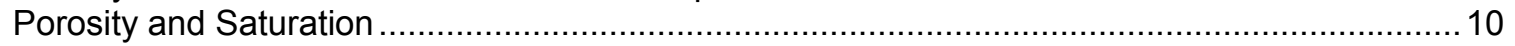

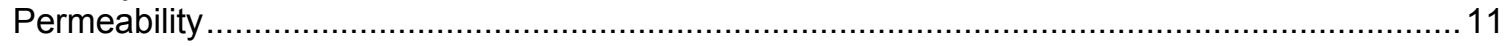

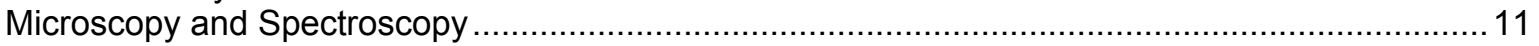

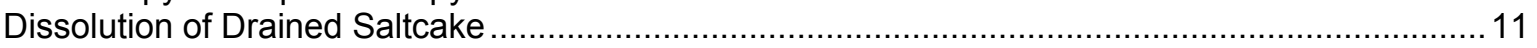

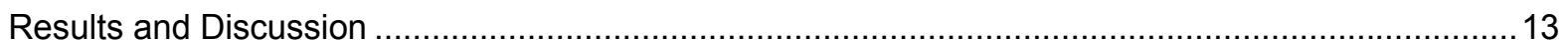

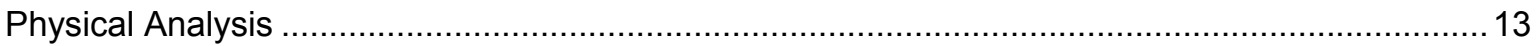

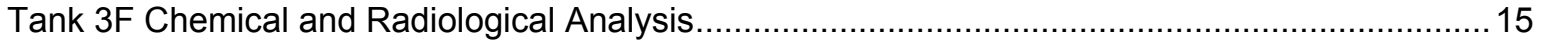

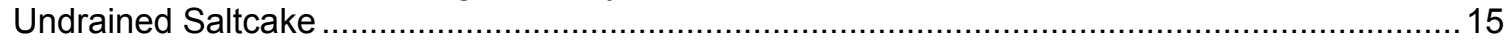

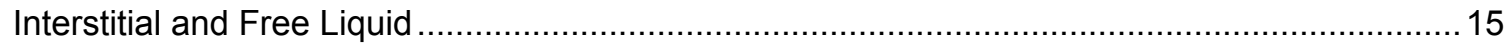

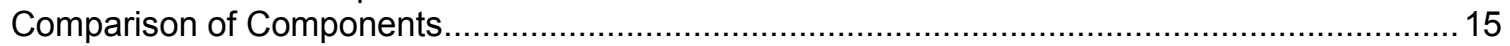

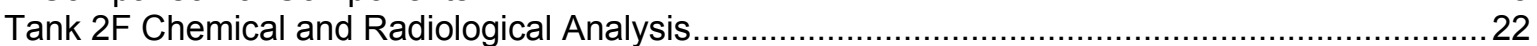

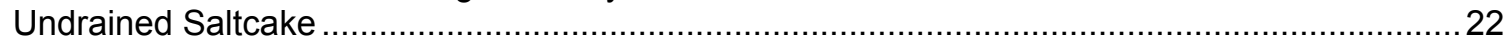

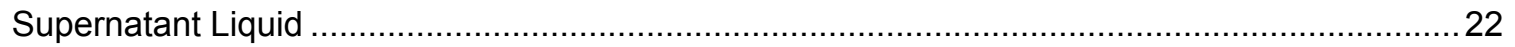

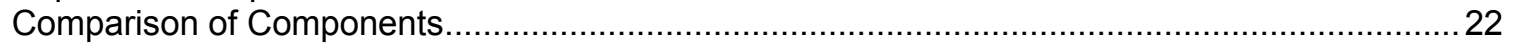

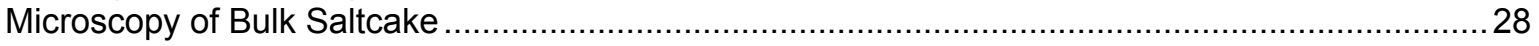

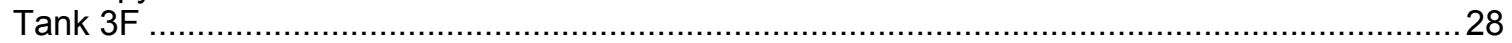

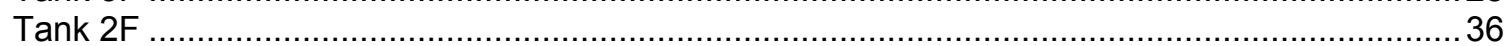

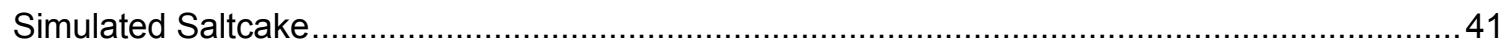

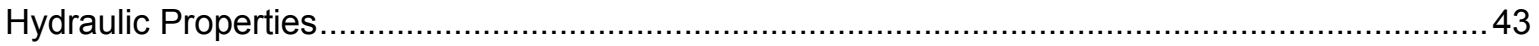

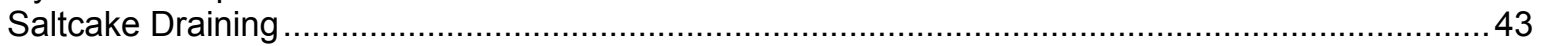

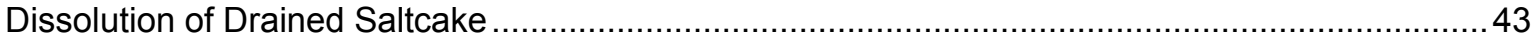

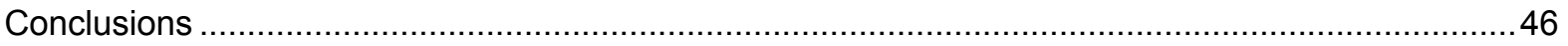

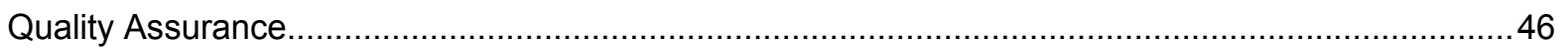

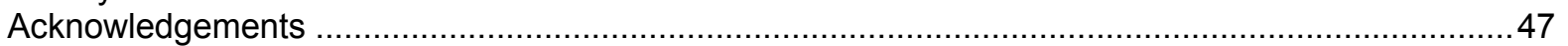

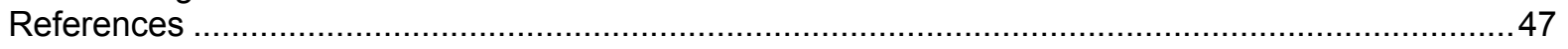

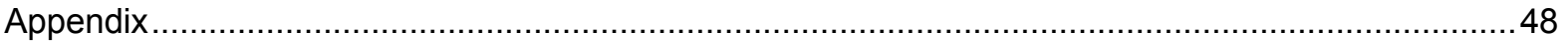


WSRC-TR-2004-00131

Revision 0

\section{List of Figures}

Cover Photo: Cutting the Tank 2F sample (foreground) while re-saturating the Tank $3 \mathrm{~F}$ sample (background) in the SRTC shielded cells

Figure 1: Material contained in Tank 3F core samples ............................................................. 2

Figure 2: Bottoms of three Tank 3F saltcake core samples. ................................................. 3

Figure 3: Salt collected from bottom of core samples................................................................ 3

Figure 4: Unfiltered Free Liquid decanted from top of core samples............................................ 3

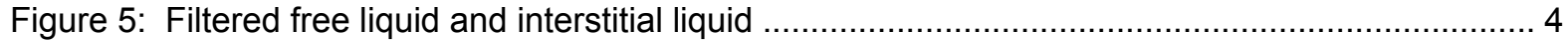

Figure 6: Tank 2F sample (T2F-1-1) received with guide pipe and mast attached .......................... 5

Figure 7: Material contained in Tank 2F core samples ........................................................... 6

Figure 8: The middle (left two figures) and bottom (right figure) of the Tank $2 \mathrm{~F}$ saltcake core sample 6

Figure 9: Salt collected from the bottom of the top portion of the Tank $2 \mathrm{~F}$ sample ........................... 7

Figure 10: Tank 2F supernate samples FTF-245 and 246, as received (unfiltered) ........................ 7

Figure 11: Apparatus used to extract interstitial liquid from saltcake samples................................ 10

Figure 12: Rough schematic of dissolution test apparatus. ..................................................... 12

Figure 13: Likely major components of Tank 3F salt solids, normalized to $100 \mathrm{wt}$. \% ..................... 22

Figure 14: Likely major components of Tank $2 \mathrm{~F}$ salt solids, normalized to $100 \mathrm{wt}$. \% ..................... 28

Figure 15: Sample T3F-1-1: Small precipitates covering large base grain (secondary electron image,

50X) Smaller crystals covering large grain (secondary electron image, 250X) ......................... 30

Figure 16: Secondary electron images on left and backscattered images on right (500X and 1000X); analyses from center of Figure 15. Elemental spectra for spots $A-C$ are contained in Figure 17.

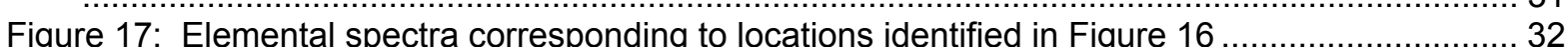

Figure 18: Results of $\mathrm{x}$-ray diffraction analysis for Sample T3F-1-1 ......................................... 33

Figure 19: Sample T3F-1-3: more massive and less pore space than previous sample (secondary electron images; $50 \mathrm{X}$ on left and $250 \mathrm{X}$ on right)

Figure 20: Backscattered images (500X and 1000X); analyses from center of Figure 19 ................ 34

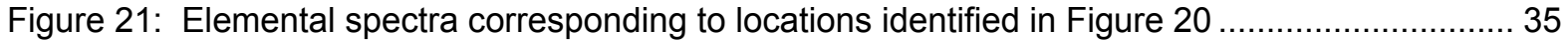

Figure 22: Results of $x$-ray diffraction analysis for Sample T3F-1-3 ........................................... 36

Figure 23: Low magnification (50X) Tank 2F Salt............................................................... 37

Figure 24: Examination of blocky, sub-rhombic, base crystal (photograph at $100 \mathrm{X}$ and elemental spectrum)

Figure 25: Examination of blocky base crystal and finer grained precipitate coatings (photograph at

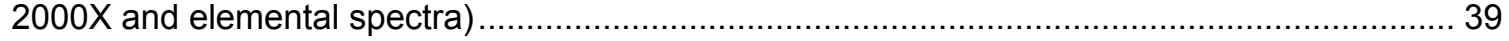

Figure 26: Example of porosity in Tank 2F Salt (500X) .......................................................... 40

Figure 27: Varying size and shape of porosity (same view as Figure 23 but higher magnification -$500 X)$

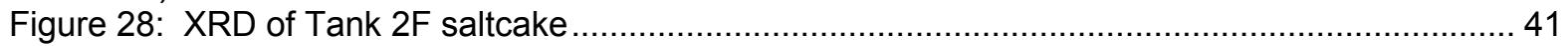

Figure 29: Photomicrograph of simulated high level waste salt. Crystal labeled "A" shows distinct crystal faces. Long dimension of photograph equals $2.2 \mathrm{~mm}$. ............................................... 42

Figure 30: Photomicrograph of fluid inclusions in simulated salt crystal. Spherical objects inside

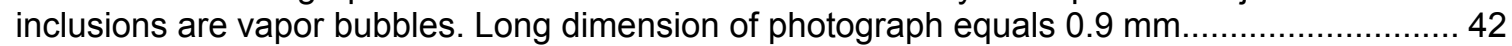

Figure 31: Tank 3F Interstitial Liquid (left) and Dissolved Samples (right) ................................... 43

Figure 32: Layer of Dark Liquid in Second Sub-Sample of Tank 3F ......................................... 44

Figure 33: T3F-1-4 flow-through dissolution profiles for ${ }^{137} \mathrm{Cs}$ and $\mathrm{Na}^{+}$(top), and anions (bottom) .. 45

Figure 34 Variability of porosity estimate based on uncertainty of estimates for input parameters, (a)

T2F, (b) T3F. 


\section{List of Tables}

Table 1: Tank 3F Sample Description ....

Table 2: Chemical composition of simulated interstitial liquid used to saturated saltcake samples for

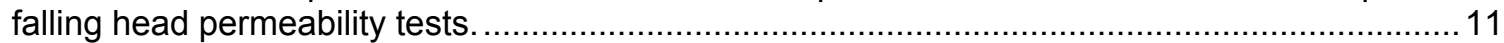

Table 3: Density and liquid content of the Tank 3F samples ................................................... 14

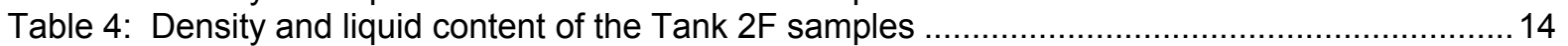

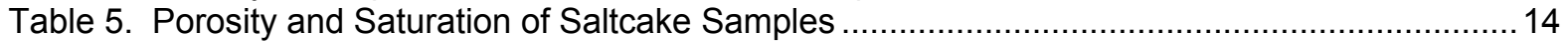

Table 6: Summary of Radiological Composition of Tank 3F Samples .......................................... 18

Table 7: Summary of lonic Composition of Tank 3F Samples ....................................................... 19

Table 8: Summary of Other Elemental Composition of Tank 3F Samples.....................................20

Table 9: Potential Streams During Draining and Dissolution of Tank 3F Saltcake ..........................21

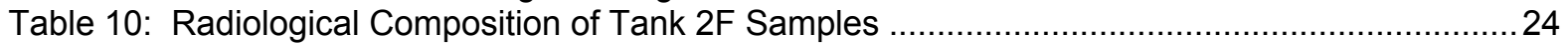

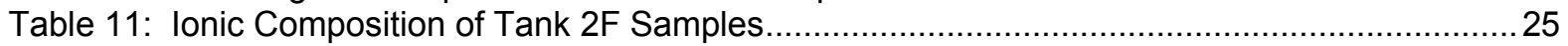

Table 12: Other Elemental Composition of Tank 2F Samples ...................................................... 26

Table 13: Potential Streams During Draining and Dissolution of Tank 2F Saltcake ..........................27

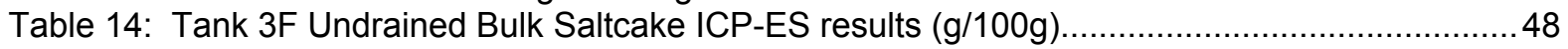

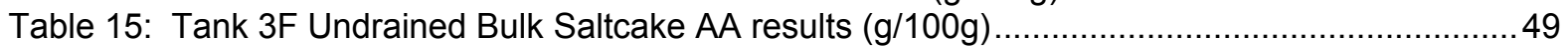

Table 16: Tank 3F Undrained Bulk Saltcake IC Anions, wet chemistry titration, and TIC/TOC results

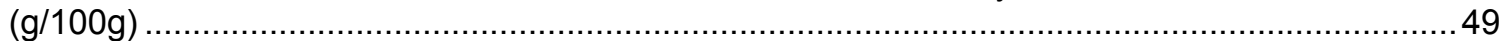

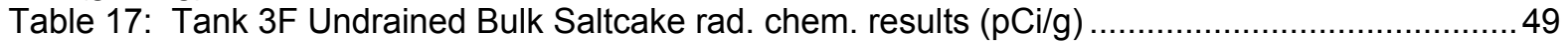

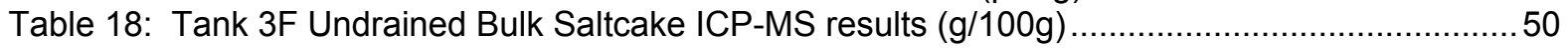

Table 19: Tank 3F Free Liquid and Interstitial Liquid ICP-ES results $(\mathrm{mg} / \mathrm{L})$.................................. 51

Table 20: Tank 3F Free Liquid and Interstitial Liquid IC Anions, wet chemistry titration, and TIC/TOC

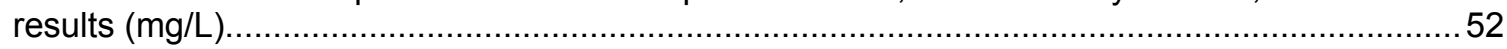

Table 21: Tank 3F Free Liquid and Interstitial Liquid rad. chem. results $(\mathrm{pCi} / \mathrm{mL}) \ldots \ldots \ldots \ldots \ldots \ldots \ldots \ldots . . . . \ldots 52$

Table 22: Tank 3F Free Liquid and Interstitial Liquid ICP-MS results $(\mathrm{mg} / \mathrm{L})$..................................53

Table 23: Likely major components of Tank 3F salt solids, normalized to $100 \mathrm{wt}$. \% .......................54

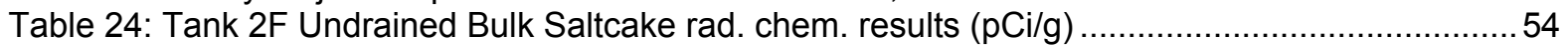

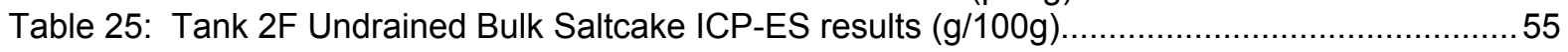

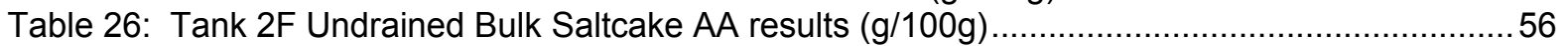

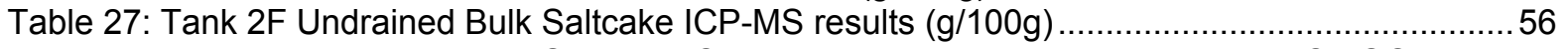

Table 28: Tank 2F Undrained Bulk Saltcake IC Anions, wet chemistry titration, and TIC/TOC results

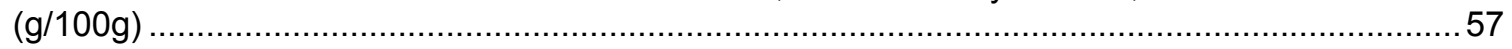

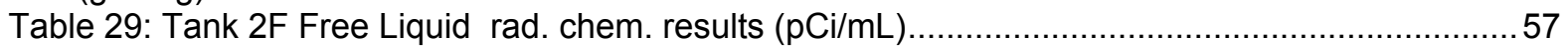

Table 30: Tank 2F Free Liquid IC anions, wet chemistry titration, and TIC/TOC results $(\mathrm{mg} / \mathrm{L})$..........58

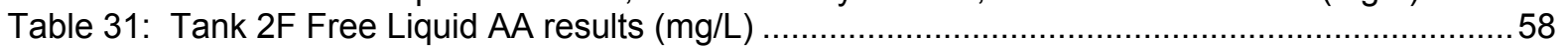

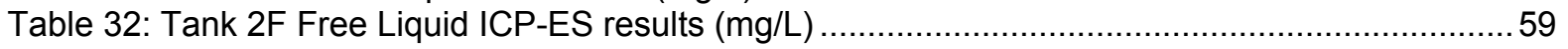

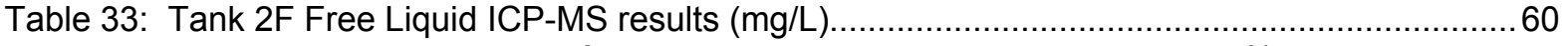

Table 34: Likely major components of Tank $2 \mathrm{~F}$ salt solids, normalized to $100 \mathrm{wt}$. \% .......................61 61

Table 35. Input and results for Monte Carlo analysis of porosity and saturation estimates................61

Table 36: Dissolution information and Radioisotopic and lonic Analysis of the Dissolution of Drained T3F-1-4

Table 37: Other Elemental Analysis of the Dissolution of Drained T3F-1-4 .................................... 64

Table 38: ICP-MS Analysis of the Dissolution of Drained T3F-1-4 (Bulk Filtered).............................65 
WSRC-TR-2004-00131

Revision 0

\section{List of Abbreviations}

$\begin{array}{ll}\text { AA } & \text { Atomic Absorption spectroscopy } \\ \text { ADDS } & \text { Adjusted Drained Dissolved Salt } \\ \text { ADS } & \text { Analytical Development Section } \\ \text { DDS } & \text { Drained Dissolved Salt } \\ \text { DI } & \text { de-ionized } \\ \text { EDS } & \text { X-ray Emission Dispersive Spectroscopy } \\ \text { FL } & \text { Free Liquid supernatant to a saltcake sample upon receipt } \\ \text { IC } & \text { lon Chromatography } \\ \text { ICP-ES } & \text { Inductively-Coupled Plasma - Emission Spectroscopy } \\ \text { ICP-MS } & \text { Inductively-Coupled Plasma - Mass Spectroscopy } \\ \text { I.D. } & \text { inner diameter } \\ \text { IL } & \text { Interstitial Liquid drained from a saltcake sample } \\ \text { LCS } & \text { Low-Curie Salt } \\ \text { LWD } & \text { Liquid Waste Disposition } \\ \text { O.D. } & \text { outer diameter } \\ \text { PLM } & \text { Polarized-Light Microscopy } \\ \text { SEM } & \text { Scanning Electron Microscopy } \\ \text { SIL } & \text { Simulated (non-radioactive) Interstitial Liquid } \\ \text { SL } & \text { Supernatant Liquid from a tank supernate sample } \\ \text { SPF } & \text { Saltstone Processing Facility } \\ \text { SRS } & \text { Savannah River Site } \\ \text { SRTC } & \text { Savannah River Technology Center } \\ \text { TIC } & \text { Total Inorganic Carbon } \\ \text { TOC } & \text { Total Organic Carbon } \\ \text { UDS } & \text { Un-drained Dissolved Salt } \\ \text { WCS } & \text { Waste Characterization System } \\ \text { XRD } & \text { X-Ray Diffraction spectroscopy }\end{array}$




\section{Introduction}

In support of Low-Curie Salt (LCS) process validation at the Savannah River Site (SRS), Liquid Waste Disposition (LWD) has undertaken a program of tank waste characterization, including salt sampling. ${ }^{1,2}$ As part of this initiative, they sampled the surface of the saltcake in Tank $3 \mathrm{~F}$ and Tank 2F using $~ 12$-inch long sample tubes. A series of three saltcake samples were taken of the upper crust in Tank $3 \mathrm{~F}$ and a single saltcake sample was taken from the bottom of a liquid-filled well in Tank $2 \mathrm{~F}$. In addition to analysis of the solid saltcake samples, the liquid contained in the Tank $3 \mathrm{~F}$ samples and a separate supernate sample from Tank $2 \mathrm{~F}$ were studied.

The primary objective of the characterization is to gather information that will be useful to the selection and processing of the next waste tanks. Most important is the determination of the ${ }^{137} \mathrm{Cs}$ concentration and liquid retention properties of Tank $3 \mathrm{~F}$ and Tank $2 \mathrm{~F}$ saltcake to enable projection of drained, dissolved salt composition. Additional information will aid in refining the waste characterization system (WCS) and could assist the eventual salt treatment or processing.

\section{Background}

Tanks $2 \mathrm{~F}$ and $3 \mathrm{~F}$ are Type I tanks located in the original grouping of eight tanks in the $\mathrm{F}$ tank farm. Both tanks currently contain saltcake, with the surface of the salt at about 200 inches of tank elevation (from the bottom of the tank), equivalent to 540,000 gallons. Originally, the tanks were used as receipt tanks for fresh high-heat waste from the mid-1950s through the mid-1960s. Subsequently, most of the sludge was removed from Tanks $2 \mathrm{~F}$ and $3 \mathrm{~F}$ and they were filled with saltcake while serving as drop tanks for the $242-\mathrm{F}(1 \mathrm{~F})$ evaporator system. ${ }^{3}$

At the time of sampling, neither tank had considerable amounts of supernatant liquid. From the draining subsequent to this sample analysis, Tank $3 \mathrm{~F}$ was found to have a crust of salt above a $\sim 40$ inch reservoir of liquid. ${ }^{4}$ The saltcake temperature at the time of Tank $2 \mathrm{~F}$ and Tank $3 \mathrm{~F}$ sampling averaged about $50{ }^{\circ} \mathrm{C}$. Tank $2 \mathrm{~F}$ had a liquid-filled trough in the saltcake below Riser 1 , an auxiliary riser located $\sim 20$ feet radially from the center riser. The salt at the bottom of this trough, corresponding to the top of the Tank $2 \mathrm{~F}$ sample, was at approximately 60 inches of tank height.

\section{Samples}

\section{Tank 3F}

On August 5, 2003, three salt core samples, FTF-223 - 225 (T3F-1-1, T3F-1-3, and T3F-1-4), were collected from Riser 1 of Tank 3F. These samples were contained in 0.95 in. inner diameter (I.D.), 1.25 in. outer diameter (O.D.), 12.7 in. long stainless steel tubes with capped ends. The samples were delivered to the Savannah River Technology Center (SRTC) and weighed on August 6. Table 1 contains a description of the three samples documented in this report. Irregular salt interfaces led to a high amount of uncertainty in the sample volumes for samples T3F-1-1 and T3F-1-4. Thus, the bulk density for T3F-1-3 is the most representative and should be used for calculations related to this entire set of Tank 3F samples. Uncertainties in the mass of free liquid contained in the samples led to uncertainty in the small mass measurement, and thus the salt mass and salt bulk density are reported as a range.

Figure 1 presents the approximate contents of the three Tank 3F samples. Note that, unlike the similar Tank $41 \mathrm{H}$ core samples, the Tank $3 \mathrm{~F}$ samples contained a significant amount of supernatant free liquid (FL). The T3F-1-4 sample tube (bottom sample) was reportedly much easier to push into the tank than the preceeding two sample above it, consistent with the presence of a liquid pool beneath a crust. Figure 2 and Figure 3 show the saltcake in the bottom of the sample tubes and the 
WSRC-TR-2004-00131

Revision 0

portions removed for analysis, respectively. Figure 4 and Figure 5 show the free liquid decanted from the top of the samples, unfiltered and filtered, respectively.

Table 1: Tank 3F Sample Description

\begin{tabular}{|c|c|c|c|c|c|c|c|}
\hline $\begin{array}{l}\text { Relative } \\
\text { Location }\end{array}$ & $\begin{array}{c}\text { Tank Farm } \\
\text { Name }\end{array}$ & $\begin{array}{l}\text { Tube } \\
\text { Name }\end{array}$ & $\begin{array}{c}\text { Approximate } \\
\text { Tank Elevation } \\
\text { (in) }\end{array}$ & $\begin{array}{l}\text { Sample } \\
\text { (salt+FL) } \\
\text { Mass (g) }\end{array}$ & Salt Mass (g) & $\begin{array}{c}\text { Salt } \\
\text { Volume } \\
\left(\mathrm{cm}^{3}\right)\end{array}$ & $\begin{array}{c}\text { Salt Bulk } \\
\text { Density } \\
\left(\mathrm{g} / \mathrm{cm}^{3}\right)\end{array}$ \\
\hline top & FTF-223 & T3F-1-1 & $200-188$ & 263.51 & 212.6 to 223.9 & $\sim 98$ & n.d. \\
\hline middle & FTF-224 & T3F-1-3 & $188-176$ & 275.32 & 259.0 to 262.5 & 126.0 & 2.06 to 2.08 \\
\hline bottom & FTF-225 & T3F-1-4 & $176-164$ & 237.04 & 117.6 to 131.9 & $\sim 56$ & n.d. \\
\hline total & & & $200-164$ & 775.87 & 589.2 to 618.2 & & \\
\hline
\end{tabular}

Tank 3F

"36 inch" Saltcake Core Sample

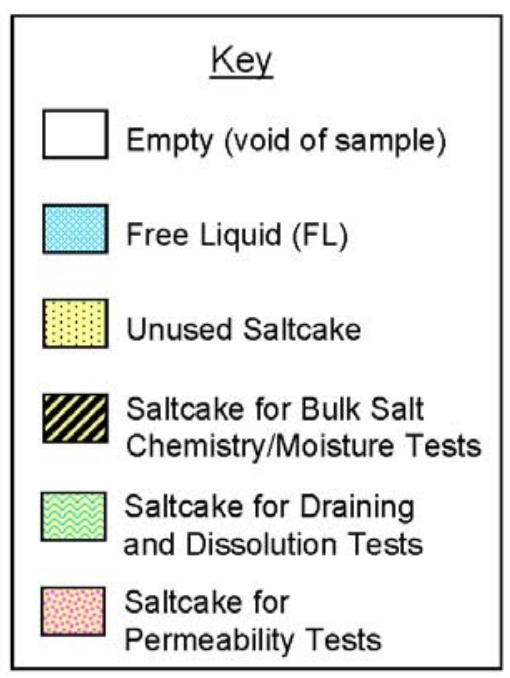

All interface levels are approximate. Small amounts of saltcake were evident in the "empty" and "free liquid" regions.

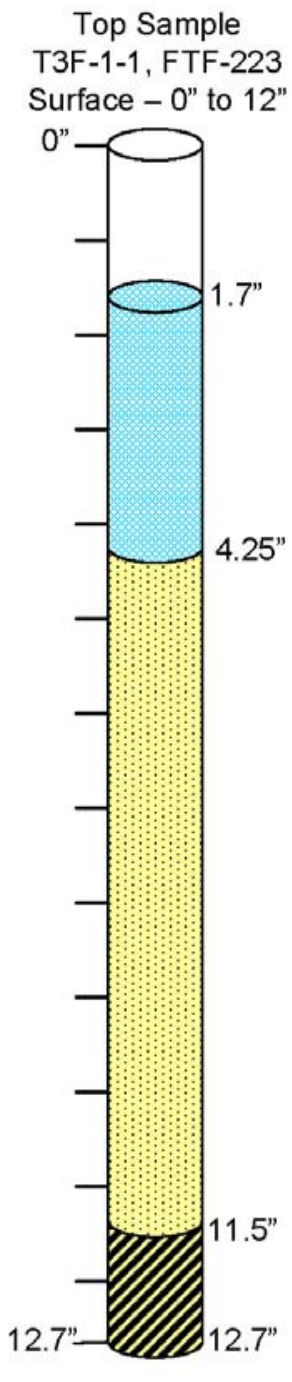

Middle Sample
T3F-1-3, FTF-224
Surface - 12" to 24"

Bottom Sample

T3F-1-4, FTF-225

Surface $-24^{\prime \prime}$ to $36^{\prime \prime}$

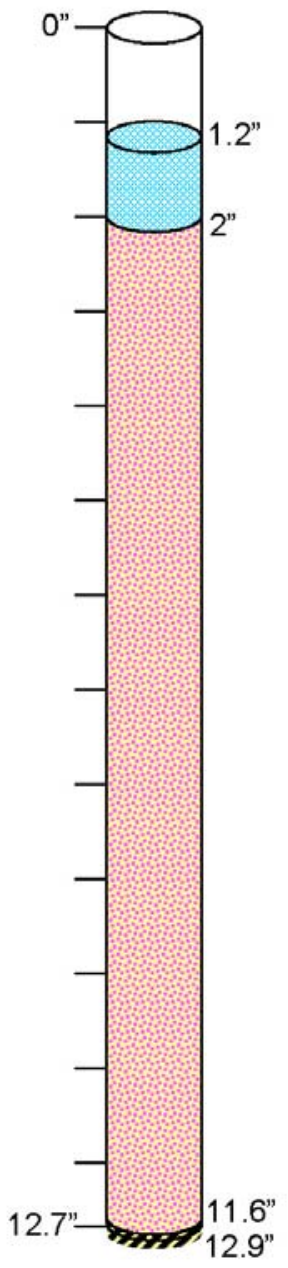

Figure 1: Material contained in Tank 3F core samples 

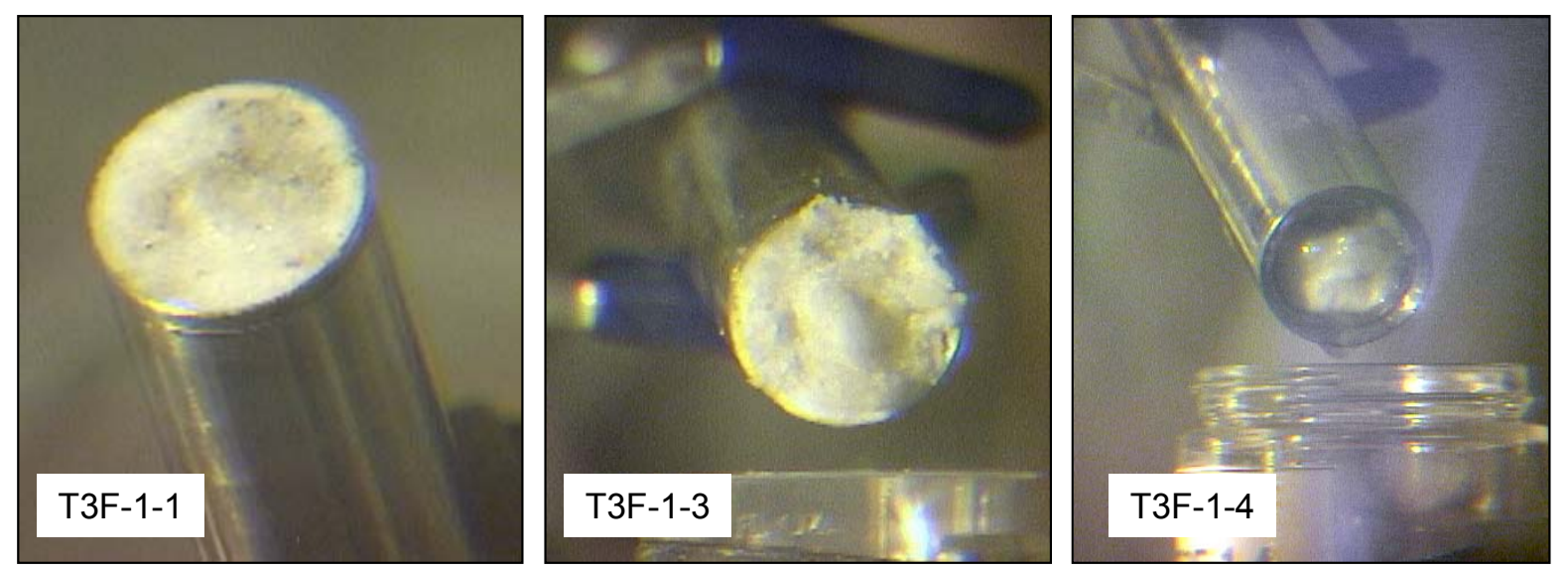

Figure 2: Bottoms of three Tank 3F saltcake core samples.

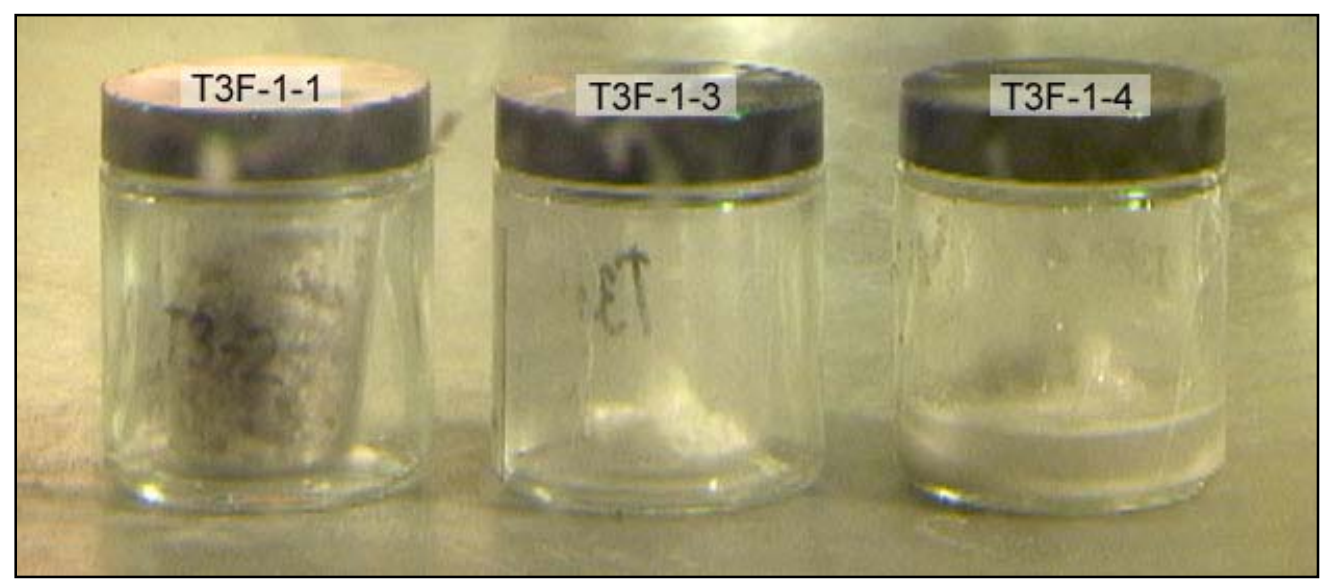

Figure 3: Salt collected from bottom of core samples
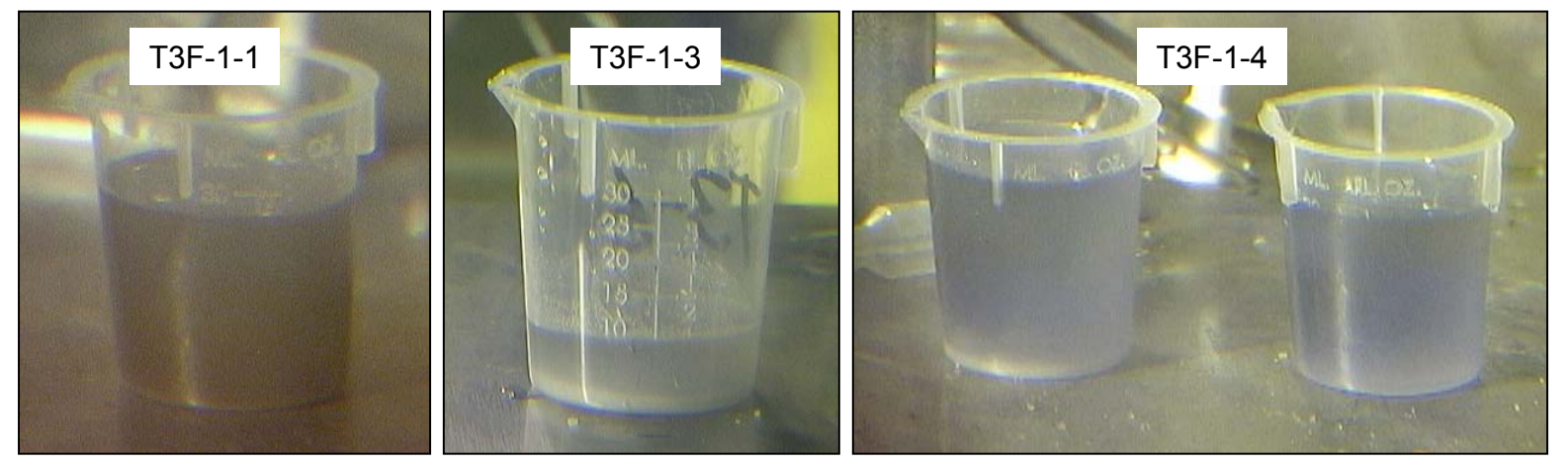

Figure 4: Unfiltered Free Liquid decanted from top of core samples 

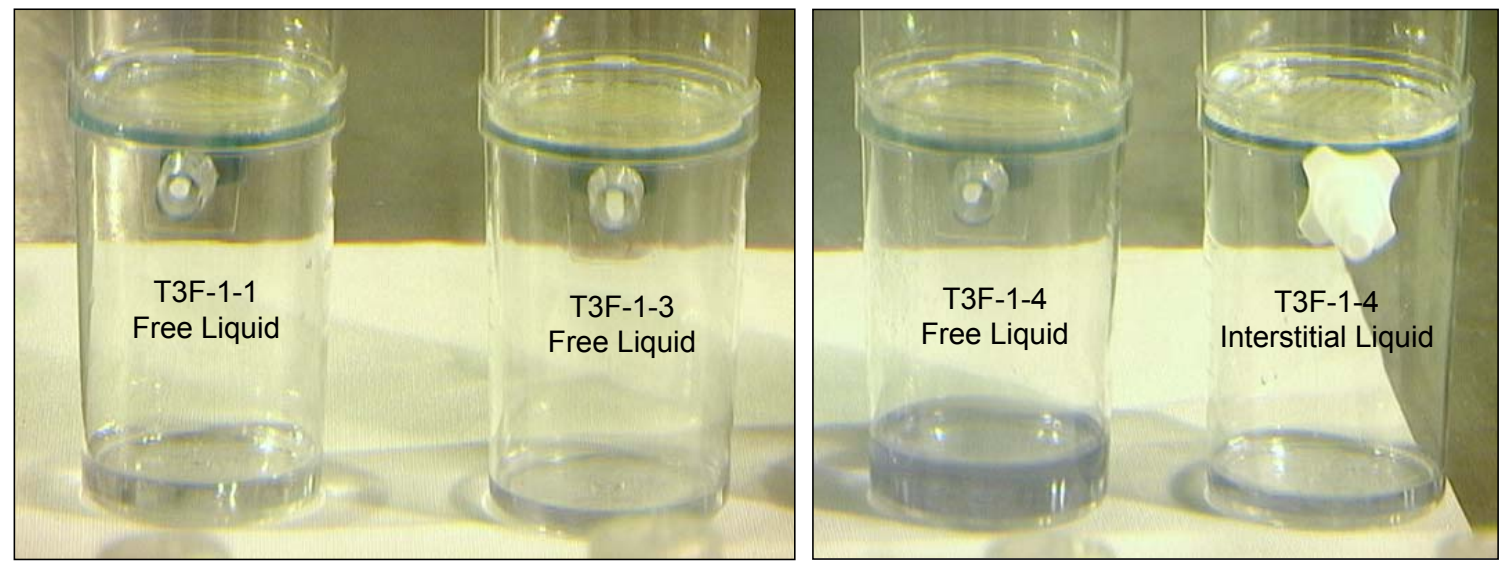

Figure 5: Filtered free liquid and interstitial liquid

T3F-1-1 Saltcake Sample:

Approximately $28 \mathrm{~mL}$ of free liquid was collected from top of T3F-1-1, with an additional $\sim 5 \mathrm{~mL}$ of free liquid lost while decanting. The liquid appeared cloudy with some brown solids. Salt was easily scooped from the bottom of T3F-1-1. Sample T3F-1-1 salt had a moist consistency, but was not soupy, and appeared to contain some darker solids. As indicated in Figure 1, the bottom portion of T3F-1-1 was sampled for chemical, radiological, and moisture content analysis and the remaining portion was retained for future testing.

\section{T3F-1-3 Saltcake Sample:}

Approximately $10 \mathrm{~mL}$ of free liquid and soupy salt was collected from the top of sample T3F-1-3. The bottom of T3F-1-3 was very full, with saltcake extending approximately 0.25 inches beyond the end of the tube (see Figure 1 and Figure 2). The T3F-1-3 salt was very hard and was more white when compared with the other samples (had less dark solids than T3F-1-1). As indicated in Figure 1, the bottom portion of T3F-1-3 was sampled for moisture content, and the remaining portion was used for re-saturation and permeability testing.

\section{T3F-1-4 Saltcake Sample:}

The top of T3F-1-4 contained a relatively large amount of supernatant free liquid, which was presumed to be similar to the Tank $3 \mathrm{~F}$ interstitial liquid (IL). Approximately $65 \mathrm{~mL}$ of liquid was collected, with an additional $\sim 10 \mathrm{~mL}$ lost while decanting. Although it is difficult to ascertain the exact color through the shielded cells window, the free liquid appeared to be light indigo or violet in color. Salt from the bottom of T3F-1-4 was wet and soupy, with some additional solid/liquid separation apparent during sample storage (see Figure 3). The other two Tank 3F saltcake samples had wet salt and liquid only at the top portion of the samples. Technicians scooping material from the sample commented that it resembled soft homemade ice cream or Mediterranean bath salts. As indicated in Figure 1, the bottom portion of T3F-1-1 was sampled for chemical, radiological, and moisture content analysis, and the remaining portion was drained and used for dissolution testing.

There were two minor issues regarding the collection and shipment of the samples. Sample T3F-1-1 (FTF-223) was shipped with the vents still attached to the shipping caps. This allowed a few milliliters of liquid to leak into the bag during shipping. The other two samples were packaged without the vents. After delivery to the tank farm, the Tank 3F sample tubes were etched with FTF numbers. These tubes had already been etched with other identifying numbers and the tare weight was known. Subsequent etching in the tank farm changed the tare weight, potentially biasing the measurement of bulk density of the saltcake samples by $\sim 1 \%$. 


\section{Tank 2F}

On August 18, 2003, LWD began a process to collect three salt core samples from Riser 1 of Tank $2 \mathrm{~F}$. The sampling procedure was interrupted, however, when the sample tube (0.95 in. I.D., 1.13 in.

O.D., 12.7 in. long) could not be retrieved through the guide pipe due to deformation during sampling. On September 10, one sample was taken and removed from the tank. This sample corresponds to material from an approximate tank elevation of 60 " to 48 ". On September 12, the sample was delivered to SRTC, placed into the shielded cells, and weighed. The sample had a portion of the guide pipe and sample mast still attached (Figure 6).

Figure 7 displays the approximate contents of the Tank $2 \mathrm{~F}$ sample. In order to complete the required analyses the sample was cut into two portions: the bottom $5.1 \mathrm{in}$. portion and the top $7.6 \mathrm{in}$. portion. After cutting, the bottom of the top portion of the sample tube protruded approximately $0.9 \mathrm{in}$. out of the sample guide pipe. Due to the limited access available for sample retrieval and the unknown guide pipe and sample mast weight, little is known about the contents of the top 6.1 inches of this sample. The bottom portion of sample T2F-1-1 contained 121.08 grams of saltcake that occupied approximately $59.4 \mathrm{~cm}^{3}$, for a bulk saltcake density of $2.04 \mathrm{~g} / \mathrm{cm}^{3}$. The bottom portion of the sample contained no free liquid. Salt for chemical analysis and water content measurement was taken from the bottom 1.5 inches of the top portion of sample T2F-1-1.

Figure 8 shows the salt visible from the ends of the sample tube. From left to right, the images are of the bottom of the top portion of the severed sample, the top of the bottom portion of the severed sample, and the bottom of the sample. Figure 9 shows the $\sim 50 \mathrm{~g}$ of salt removed from the bottom of the top half of the sample. The salt was dry and granular. Although the salt was hard packed, it was easily scooped from the sample tube. Reflections of light off of flat crystal surfaces indicated that some grains were on the scale of millimeters.
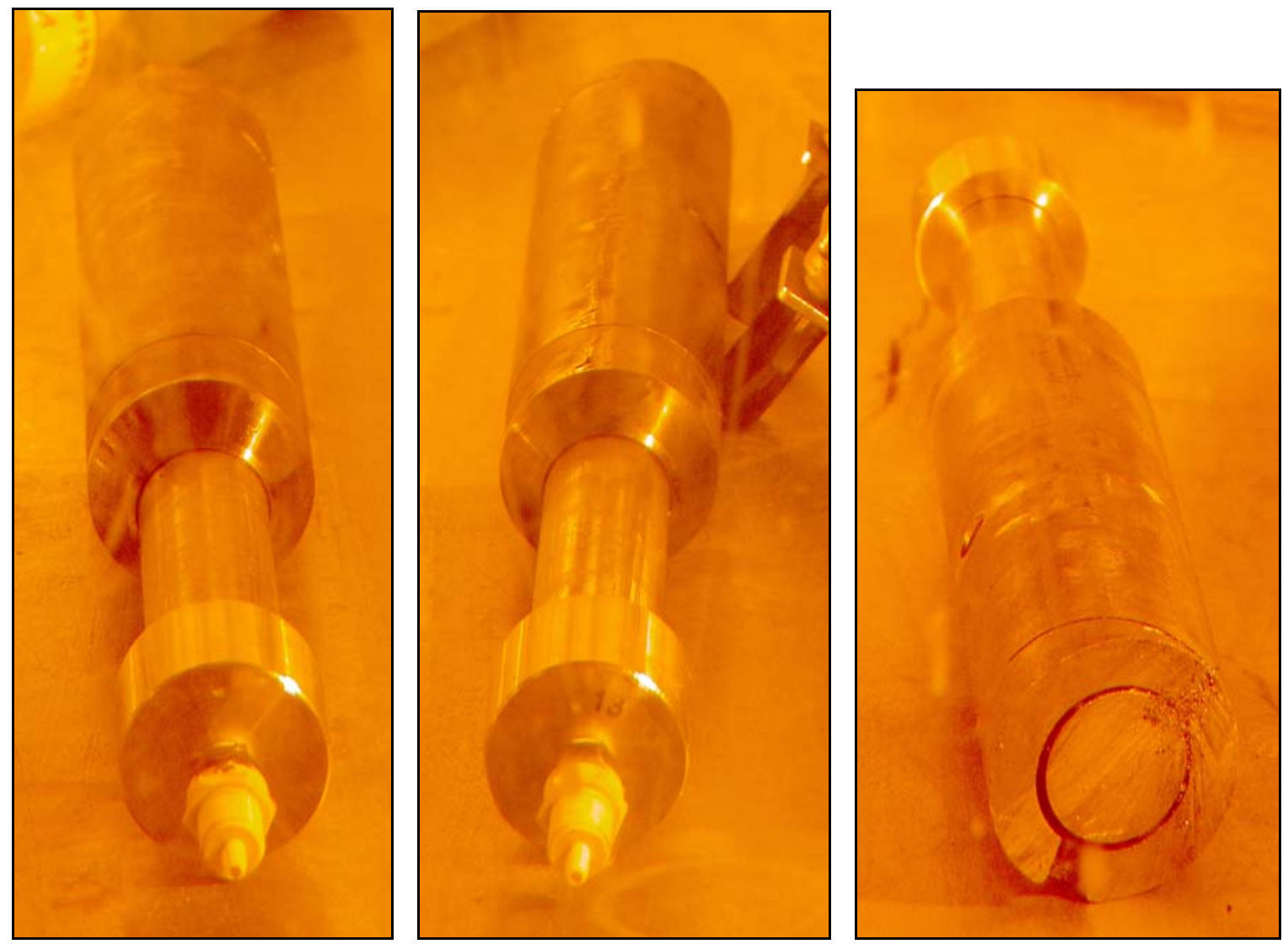

Figure 6: Tank 2F sample (T2F-1-1) received with guide pipe and mast attached 
WSRC-TR-2004-00131

Revision 0

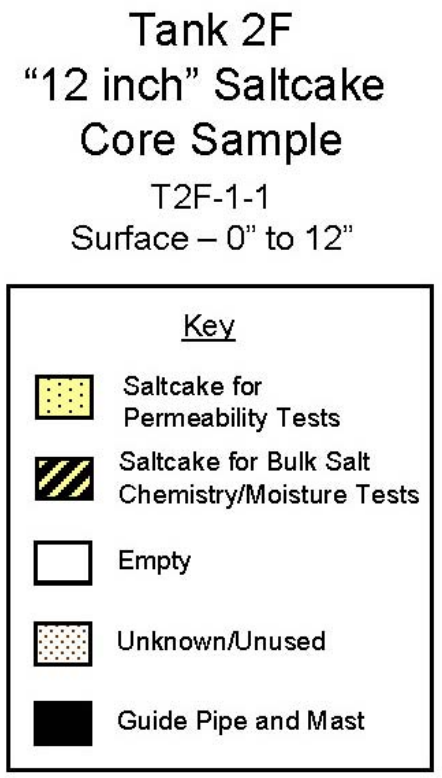

Interface levels are approximate. Tube was severed at $\sim 7.6$ " mark.

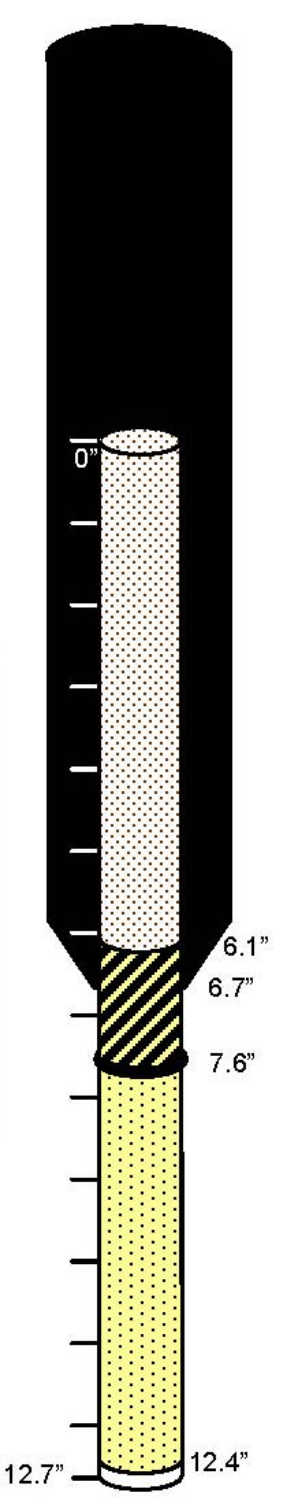

Figure 7: Material contained in Tank 2F core samples
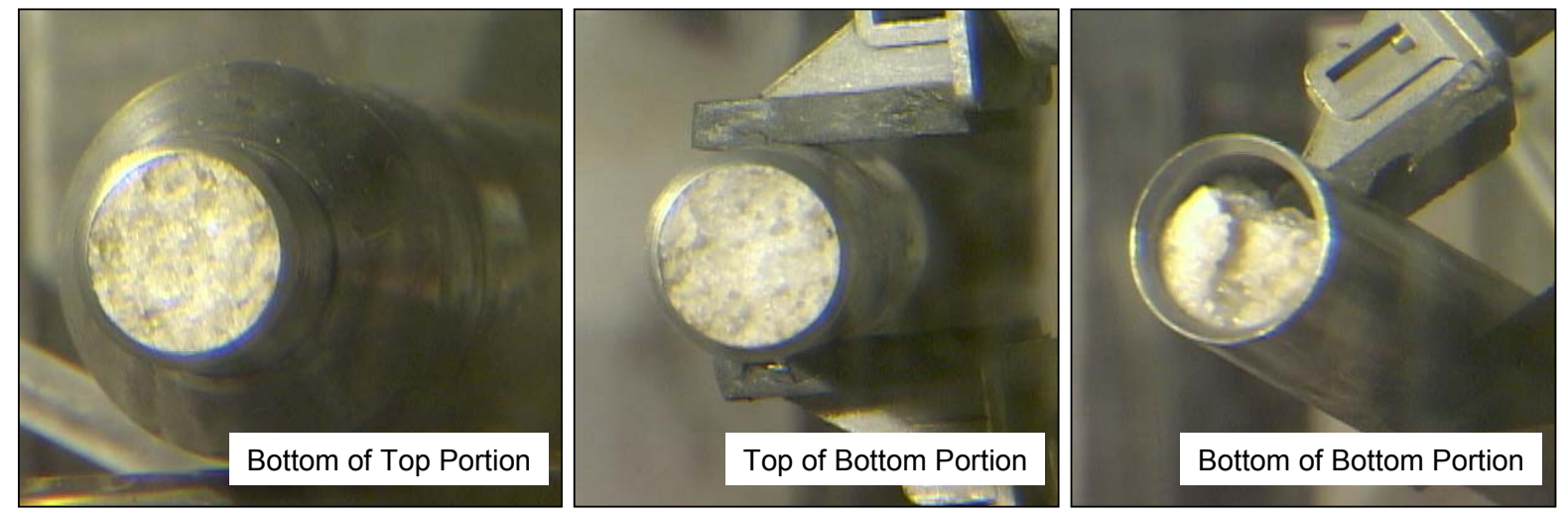

Figure 8: The middle (left two figures) and bottom (right figure) of the Tank 2F saltcake core sample 


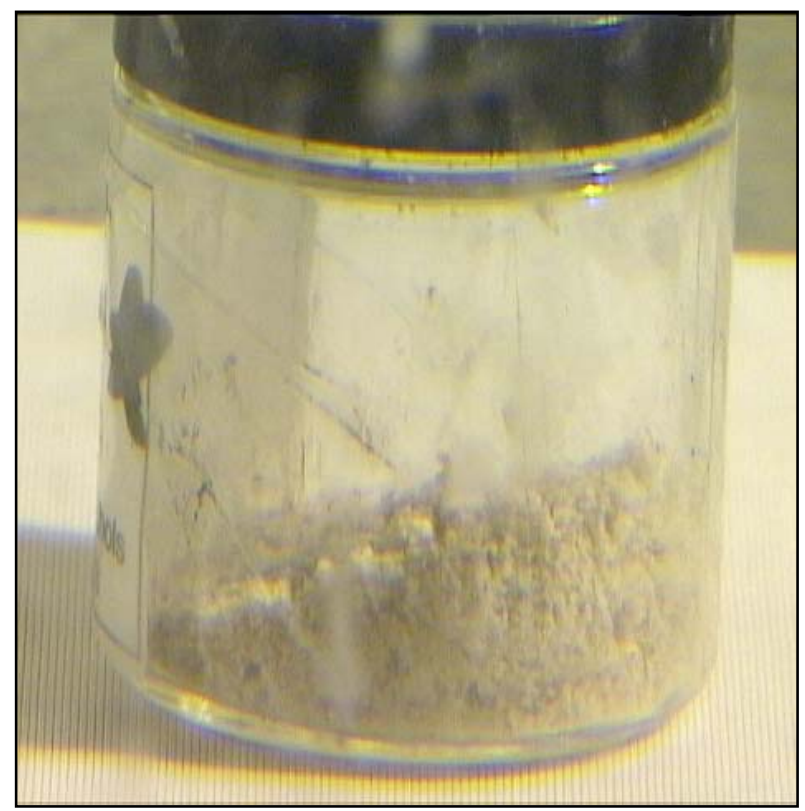

Figure 9: Salt collected from the bottom of the top portion of the Tank 2F sample

On September 10, 2003, SRTC received two Tank 2F supernate samples (FTF-245 and 246), which were variable-depth samples pulled from the 150" elevation of riser 1 (total liquid level was 199 inches). The two $80 \mathrm{~mL}$ samplers contained a combined $\sim 90 \mathrm{~mL}$ of supernate. The Tank $2 \mathrm{~F}$ samples contained blue to green liquid with only a small amount of cloudiness, indicating only small amounts of insoluble solids (Figure 10).

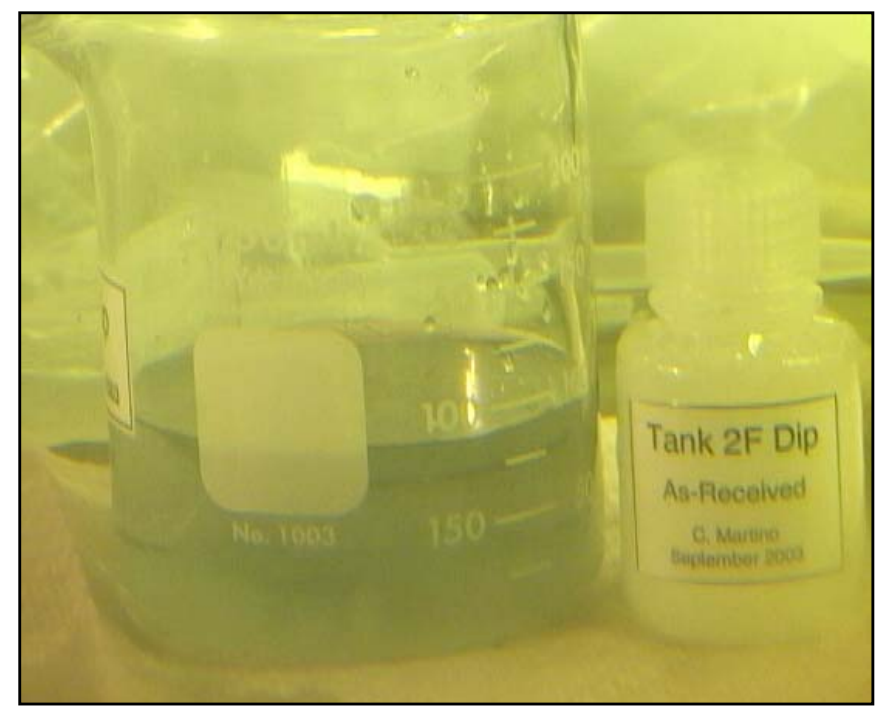

Figure 10: Tank 2F supernate samples FTF-245 and 246, as received (unfiltered) 
WSRC-TR-2004-00131

Revision 0

\section{Experimental}

\section{Chemical and Radiological Analysis}

\section{Saltcake Core Samples}

The Tank 3F samples were weighed, uncapped, and visually inspected upon receipt in the shielded cells. Free liquid was removed from the tops of the samples and this liquid was filtered and analyzed. Characterization was performed on undrained bulk salt using small portions of salt removed from the bottom of the sample tubes. Greater than 30 grams of salt was removed from the bottoms of the uppermost (T3F-1-1) and lowermost (T3F-1-4) samples and analyzed for water content, salt chemistry, and radiological counting. About 5 grams of salt was removed from the bottom of the middle (T3F-1-3) sample and analyzed for water content only. Sample T3F-1-4 was gravity drained and vacuum drained for two days, and the drained interstitial liquid was filtered and analyzed. For Tank 3F, free liquid and interstitial liquid subsamples were prepared for analysis by filtering through a 0.45 -micron filter and diluting with $2 \mathrm{M}$ nitric acid and DI water.

The Tank $2 \mathrm{~F}$ sample was weighed, uncapped, and visually inspected upon receipt in the shielded cells. The sample was cut into two segments as shown in Figure 7 . About $20 \mathrm{~g}$ of salt was removed from the bottom of the top portion of T2F-1-1 for undrained bulk salt analysis. The remaining portion of the top half of the sample could not be accessed because the guide pipe and mast could not be removed.

Undrained bulk salt subsamples were prepared for analysis by aqua regia (nitric and hydrochloric acid) dissolution and by deionized (DI) water dissolution. The dissolutions were performed by dissolving approximately 2 grams of the material into $100 \mathrm{~mL}$ of liquid. For the DI water dissolutions, aliquots were taken from the liquid portion after dissolving, agitation, and settling, although no significant residual solids were visible.

The aqua regia dissolutions were submitted to radiological chemistry for ${ }^{137} \mathrm{Cs}$ (gamma scan), $\mathrm{Pu}$ isotopics, ${ }^{241} \mathrm{Am}$, and ${ }^{90} \mathrm{Sr}$, inductively coupled plasma - emission spectroscopy (ICP-ES) for elemental analysis, inductively coupled plasma - mass spectroscopy (ICP-MS) for certain actinide and fission product quantification, and atomic absorption (AA) spectroscopy for the measurement of $\mathrm{As}, \mathrm{Se}, \mathrm{Hg}$, and $\mathrm{K}$. The DI water dilutions/dissolutions were submitted for ion chromatography (IC) for anion characterization, wet chemistry/titration for total base, free hydroxide, and $\mathrm{CO}_{3}{ }^{2-}$ analysis, and total inorganic and organic carbon (TIC/TOC) analysis. An additional portion of the water-dissolved salt samples were submitted for ${ }^{14} \mathrm{C}$ analysis.

To obtain a total concentration, several analytes require assumptions to be made or calculations from multiple analytical methods. The ${ }^{99} \mathrm{Tc}$ is reported as a maximum value based on the entire mass 99 data from ICP-MS, and thus ignores any contribution of ${ }^{99} \mathrm{Ru}$. If there were any natural abundance ruthenium present, the amount would be in proportion to the mass 101 values. Since it is not possible to determine the amount of natural and fission product ruthenium, it is not feasible to calculate the contribution of ${ }^{99} \mathrm{Ru}$ to the mass 99 value. In any event, the contribution is likely small as the mass 101 value rarely exceeds $5 \%$ of the mass 99 value. The ${ }^{135} \mathrm{Cs}$ is reported as a maximum value based on the entire mass 135 data, and thus ignores any contribution of ${ }^{135} \mathrm{Ba}$. This provides a good measurement for the filtered liquid samples because of the limited Ba solubility. Total Cs is calculated as the sum of ${ }^{133} \mathrm{Cs}$ from ICP-MS and ${ }^{137} \mathrm{Cs}$ from radiochemistry. The calculation of total Cs does not contain the ${ }^{135} \mathrm{Cs}$ contribution, which is always relatively small ( $<10 \mathrm{wt} \%$ of total Cs). The total strontium in the saltcake sample was estimated based on the ICP-MS measurement of mass 88, assuming a natural abundance of ${ }^{86} \mathrm{Sr}$ and ${ }^{87} \mathrm{Sr}$, and combining it with the mass of ${ }^{90} \mathrm{Sr}$ from radiochemistry counting. This causes a small overestimation of the total strontium as the ${ }^{86} \mathrm{Sr}$ and ${ }^{87} \mathrm{Sr}$ would actually be less abundant because some of the ${ }^{88} \mathrm{Sr}$ is present as a fission product.

Total Co is reported as mass 59, and thus may be biased high in the presence of organic or inorganic components that fragment at mass 59. An alternative free hydroxide estimate is provided as a 
calculated value by taking the total base and subtracting the contribution of aluminate and carbonate ions. Total inorganic carbon is reported as mass of $\mathrm{CO}_{3}{ }^{2-}$ and total organic carbon is reported as mass of carbon.

\section{Supernate Samples}

Upon entry into the SRTC shielded cells, the two supernate samples (HTF-245 and 246) were combined in a glass beaker and visually observed. A small $(2 \mathrm{~mL})$ portion of the as-received sample was retained for unfiltered analysis. The sample was filtered through 0.45-micron and 0.1-micron filters, and portions of the filtered samples were analyzed.

Unfiltered and filtered supernate subsamples were prepared for analysis by pressurized nitric/hydrofluoric acid dissolution and by DI water dilution. The dissolutions/dilutions were performed by dissolving/diluting approximately 2 grams of the sample with $100 \mathrm{~mL}$ of liquid. Pressurized nitric/hydrofluoric acid dissolutions of the filtered and unfiltered samples were submitted for analysis of the same components as were the acid dissolutions of the core samples. The analyses included radiological chemistry, ICP-ES, ICP-MS, and AA. The water dilutions of the filtered samples were submitted for IC, wet chemistry titration, TIC/TOC, and ${ }^{14} \mathrm{C}$ analysis.

\section{Draining in Vacuum Extraction Cell}

Interstitial liquid (IL) was extracted from sample T3F-1-4 using 5" Hg vacuum for 39 hours. Figure 11 shows the apparatus used to extract the IL. A 100 mesh stainless steel screen was placed in the bottom shipping cap to retain salt particles in the sample tube during vacuum extraction. The mass of the liquid collected from the sample was measured periodically.

\section{Physical Properties Analysis}

\section{Density, Moisture, and Percent Interstitial Liquid}

The saltcake bulk density of the as-received material was calculated from a direct measurement of the sample weight and an estimate of the filled volume while the sample was still in a portion of the thin walled sample tube. Densities of the interstitial, free, and supernatant liquids were measured as the weight of material required to fill $2 \mathrm{~mL}$ Class A volumetric flasks. The water content of the saltcake $\left(\theta_{w}\right)$ and liquid samples $\left(\chi_{w}\right)$ were estimated gravimetrically: small portions $(\sim 1 \mathrm{~g})$ of saltcake or liquid were dried at $115^{\circ} \mathrm{C}\left( \pm 5^{\circ} \mathrm{C}\right)$ to drive off water until a constant weight had been achieved. The solids collected from the filtration of the supernate samples were washed with water and dried for determination of insoluble solids content. 
WSRC-TR-2004-00131

Revision 0

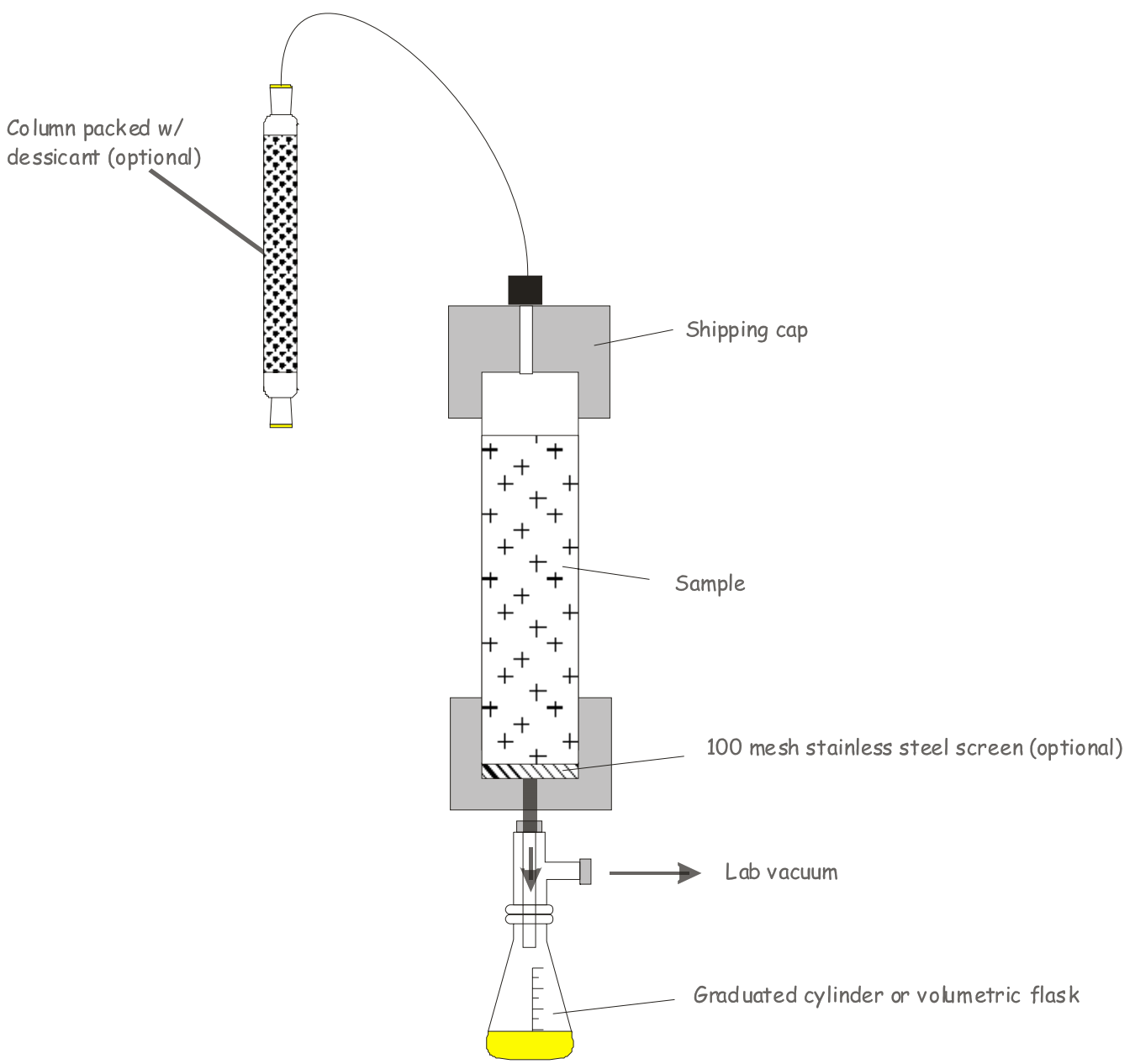

Figure 11: Apparatus used to extract interstitial liquid from saltcake samples.

Porosity and Saturation

The porosity and saturation of saltcake samples were estimated using the following equations.

$$
\begin{gathered}
\phi=\frac{V_{\text {voids }}}{V_{\text {total }}}=\frac{V_{\text {total }}-V_{\text {solid }}}{V_{\text {total }}} \\
V_{\text {solid }}=\frac{W_{\text {solid }}}{\rho_{\text {solid }}}=\frac{W_{\text {total }}-W_{\text {liquid }}}{\rho_{\text {solid }}} \\
\left.W_{\text {liquid }}=\left(\frac{W_{\text {total }}}{\chi_{\text {wIL }}}\right) \theta_{\text {w }}\right) \\
S=\frac{V_{\text {liquid }}}{V_{\text {voids }}}=\frac{\left(\frac{W_{\text {liquid }}}{\rho_{\text {liquid }}}\right)}{\left(V_{\text {total }} * \phi\right)}
\end{gathered}
$$




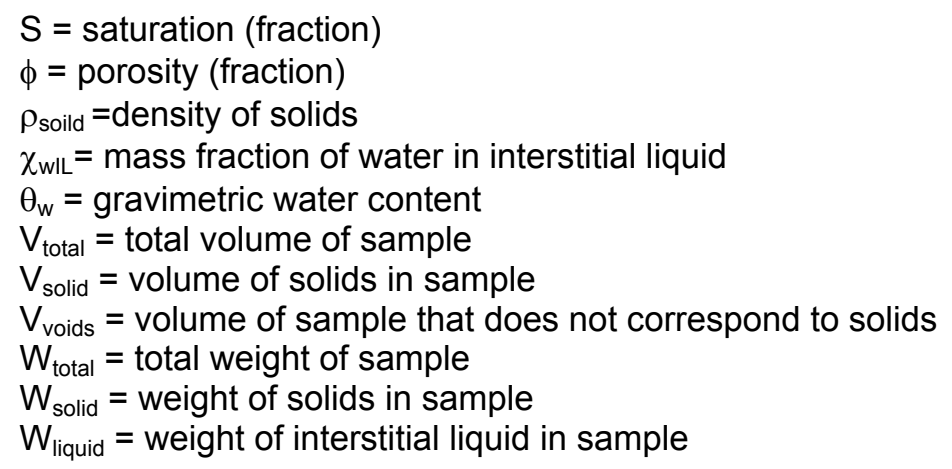

Uncertainty in the density of the interstitial liquid, weight percent water, density of solids, and mass fraction of water in interstitial liquid was incorporated into the porosity estimate by performing a Monte Carlo analysis using Crystal Ball 2000 (by Decisioneering, Inc.), an add-in for MS Excel.

\section{Permeability}

A falling head permeability test was conducted on samples T2F-1-1 and T3F-1-3 to measure the permeability of saltcake samples collected from Tank $2 \mathrm{~F}$ and Tank $3 \mathrm{~F}$. The permeability test method was similar to that used on saltcake samples from Tank $41 \mathrm{H} .{ }^{5}$ Neither sample was drained prior to initiating saturation with simulated interstitial liquid (SIL). The chemical composition of SIL used for Tanks $2 \mathrm{~F}$ and $3 \mathrm{~F}$, as shown in Table 2, was based on results from the analysis of supernate samples from Tank $3 \mathrm{~F}$ and consisted of a $12.8 \mathrm{M} \mathrm{Na}^{+}$solution with $\left[\mathrm{OH}^{-}\right] /\left[\mathrm{NO}_{3}{ }^{-}\right]$of 2.6 and density of 1.39 $\mathrm{g} / \mathrm{mL}$.

Table 2: Chemical composition of simulated interstitial liquid used to saturated saltcake samples for falling head permeability tests.

\begin{tabular}{|c|c|}
\hline \hline Component & Concentration \\
\hline $\mathrm{NaOH}$ & $8 \mathrm{M}$ \\
\hline $\mathrm{NaAlO}$ & $0.58 \mathrm{M}$ \\
\hline $\mathrm{NaNO}_{3}$ & $1.75 \mathrm{M}$ \\
\hline $\mathrm{NaNO}_{2}$ & $2.28 \mathrm{M}$ \\
\hline $\mathrm{Na}_{2} \mathrm{CO}_{3}$ & $0.15 \mathrm{M}$ \\
\hline
\end{tabular}

\section{Microscopy and Spectroscopy}

Portions of the saltcake samples were investigated by scanning electron microscopy (SEM) with energy dispersive spectroscopy (EDS). Preparation for SEM involved drying and plating the material with $\mathrm{Au}$ and $\mathrm{Pd}$. Separate portions of the saltcake samples were investigated by X-ray diffraction (XRD). Additionally, portions of a saltcake simulant were investigated by polarized light microscopy (PLM) using a petrographic microscope.

\section{Dissolution of Drained Saltcake}

Figure 12 contains a generalized illustration of the apparatus used during dissolution testing of T3F-14. The apparatus utilized the salt core sample contained in the original stainless steel sampling tube. The dissolution apparatus was essentially the same as the vacuum-extraction apparatus, with the exception of the media bag for water introduction. During sample dissolution, the orientation of the 
Tank 3F sample was the same as the in-tank orientation. In this configuration, the larger void in the sample tube was at the top of the dissolution apparatus. Prior to dissolution, T3F-1-4 was drained of a portion of its IL content by the method described in the previous sections. The dissolution protocol did not use a screen or filter at the bottom of the sample tube.

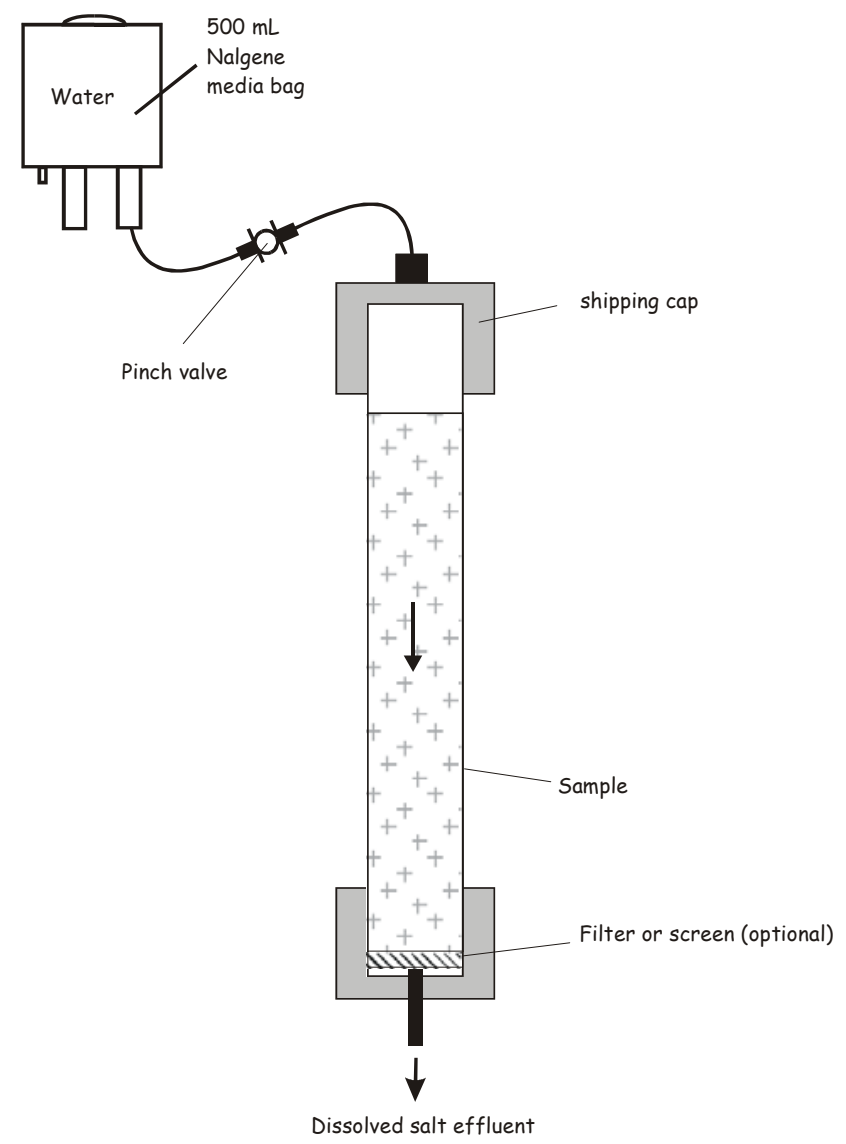

Figure 12: Rough schematic of dissolution test apparatus.

DI Water was introduced to the top of the sample tube via a media bag and the dissolved salt effluent was collected from the bottom of the sample. The rate of water introduction could be roughly controlled by a pinch valve, but the rate of effluent elution was limited by the saltcake physical properties. In most cases, gravity is the primary force driving the fluid through pores and channels in the dissolving saltcake. In some instances, however, liquid would not be evident at the bottom of the sample after a significant period of time. In those cases, vacuum was applied to the bottom of the sample in a manner similar to the process for draining interstitial liquid from samples.

The dissolved salt effluent was periodically sampled in $5 \mathrm{~mL}$ aliquots. The collection of these aliquots was timed to obtain an estimate of the effluent flow rate. These aliquots were weighed to obtain the effluent density. During periods of salt dissolution when an aliquot was not collected, the dissolved salt effluent was collected in a larger graduated bottle. For the remainder of this report, the small aliquots are referred to as sub-samples of drained/dissolved saltcake and the larger bottles of effluent are referred to as the bulk drained/dissolved saltcake.

Analysis of the composite bulk drained/dissolved saltcake was performed after filtration of the material through a 0.45 -micron filter. However, analysis of sub-samples taken at various stages throughout the flow-through dissolution process was performed without filtration. Subsamples were prepared for chemical and radiochemical analyses at 20 to 50 -times dilutions with $2 \mathrm{M}$ nitric acid and 
DI water. The nitric acid dilutions were submitted for the same analyses as were the acid dissolutions of the core samples. The analyses included radiological chemistry, ICP-ES, ICP-MS, and AA. The water dilutions were submitted for IC, wet chemistry titration, and TIC/TOC.

\section{Results and Discussion}

Tabulated results for the undrained saltcake are reported in the report body and in the appendix as the average and the standard deviation of the analysis of triplicate dissolutions. The interstitial liquid, free liquid, and supernatant liquid results are reported as the average of two or three analyses of a single dilution or dissolution, with the standard deviation only appearing in the appendix. Values reported as their detection limits are preceded by " $<$ " and values that contain an average of detectable concentrations and detection limits are preceded by "</=". Blank values in the tables, "--", are either not determined or not applicable.

\section{Physical Analysis}

Table 3 and Table 4 summarize the physical properties of the saltcake and salt solution samples characterized in this program for Tanks $3 \mathrm{~F}$ and $2 \mathrm{~F}$, respectively. They include values for the density, weight percent water, weight and volume percent liquid, porosity and saturation.

The average and standard deviations for several determinations of water content and density measurements are provided. The undrained saltcake is the bulk core sample material after removal of the free liquid. The free liquid $(F L)$ is the liquid that was separate from the salt in the state that the core sample was received. The interstitial liquid (IL) is the filtered liquid that is drained from the sample using the vacuum draining apparatus. The supernatant liquid (SL) is the liquid surface or variable depth samples that were pulled separately. The SL was analyzed both filtered and unfiltered. The Drained, Dissolved Salt (DDS) solution is the solution produced after draining the saltcake and dissolving it in water (it should be noted that this solution is not likely saturated in salts).

The median of the density range reported for T3F-1-3, the one sample for which an estimate could be obtained, was $2.07 \mathrm{~g} / \mathrm{mL}$. The Tank $2 \mathrm{~F}$ saltcake sample bulk density was $2.04 \mathrm{~g} / \mathrm{mL}$ The water content of the bottoms of the three Tank $3 \mathrm{~F}$ samples were $8.5,5.1$, an $16.8 \mathrm{wt} \%$. This wide range of moisture contents of the different salt samples supports the observation that the samples have different sheens and consistencies, as noted in the sample description and shown in Figure 2 and Figure 3. The Tank 2F sample was relatively dry (akin to T3F-1-3), with a water content of $6.2 \mathrm{wt} \%$. The densities of all IL, FL, and SL samples from Tanks $3 F$ and $2 F$ ranged from 1.47 to $1.52 \mathrm{~g} / \mathrm{mL}$. The water content of the IL and FL from T3F-1-4 and the SL from Tank $2 \mathrm{~F}$ were also determined, ranging from $47.8 \mathrm{wt} \%$ to $50.2 \mathrm{wt} \%$. The water content of the FL in the other Tank $3 \mathrm{~F}$ samples was estimated.

The interstitial liquid content of the Tank $3 \mathrm{~F}$ and $2 \mathrm{~F}$ saltcake is calculated with the following two equations.

$$
\begin{gathered}
\text { Liquid in Saltcake }(\mathrm{wt} \%)=\frac{\text { Water in Saltcake }(\mathrm{wt} \%)}{\text { Water in Liquid }(\mathrm{wt} \%)} \\
\text { Liquid in Saltcake }(\mathrm{vol} \%)=\text { Liquid in Saltcake }(\mathrm{wt} \%) \times \frac{\text { Density of Saltcake }(\mathrm{g} / \mathrm{mL})}{\text { Density of Liquid }(\mathrm{g} / \mathrm{mL})}
\end{gathered}
$$

The interstitial liquid analysis for T3F-1-4 is used in the calculations for all Tank 3F samples. Because interstitial liquid was never drained from the Tank $2 \mathrm{~F}$ sample for measurement, the interstitial liquid properties are not known. It is likely that the supernatant liquid from the variable depth samples was similar in composition to the Tank $2 \mathrm{~F}$ interstitial liquid. 
Table 5 contains a comparison of the physical aspects of several salt samples, including the recent estimates of porosity and saturation. The details of the porosity and saturation calculations are included in the appendix in Table 35 and Figure 34. The bulk density of saltcake samples from Tanks $2 \mathrm{~F}$ and $3 \mathrm{~F}$ are $7 \%$ greater than the bulk density for the drained saltcake samples collected from Tank $41(1.92 \mathrm{~g} / \mathrm{mL})$. The larger bulk density is most likely due to a higher IL content in samples from Tanks $2 \mathrm{~F}$ and $3 \mathrm{~F}$ since these tanks had not been drained prior to sampling. The porosity of the Tank $2 \mathrm{~F}$ sample was $20 \%$ larger than the sample from Tank $3 \mathrm{~F}$. There is more uncertainty in the porosity estimate for Tank 3F, see Figure 34, due to the large variation in IL content of the subsamples collected from T3F-1-3.

Table 3: Density and liquid content of the Tank 3F samples

\begin{tabular}{|c|c|c|c|c|c|c|c|c|c|c|c|c|c|c|c|c|c|}
\hline \multirow{3}{*}{ Analyte } & \multirow{3}{*}{ unit } & \multicolumn{4}{|c|}{ T3F-1-1 } & \multicolumn{4}{|c|}{ T3F-1-3 } & \multicolumn{8}{|c|}{ T3F-1-4 } \\
\hline & & \multicolumn{2}{|c|}{ undrained salt } & \multicolumn{2}{|c|}{ FL (filtered) } & \multicolumn{2}{|c|}{ undrained salt } & \multicolumn{2}{|c|}{ FL (filtered) } & \multicolumn{2}{|c|}{ undrained salt } & \multicolumn{2}{|c|}{ FL (filtered) } & \multicolumn{2}{|c|}{ IL (filtered) } & \multicolumn{2}{|c|}{ DDS (filtered) } \\
\hline & & \begin{tabular}{|l|} 
average \\
\end{tabular} & stdev & average & stdev & average & stdev & average & stdev & average & stdev & average & stdev & average & stdev & average & stdev \\
\hline Density & $\mathrm{g} / \mathrm{mL}$ & -- & & 1.47 & 0.005 & 2.07 & - & 1.50 & -- & -- & & 1.52 & 0.010 & 1.49 & - & 1.19 & -- \\
\hline Water & wt \% & $8.5 \%$ & $0.5 \%$ & $\sim 52 \%$ & -- & $5.1 \%$ & $2.6 \%$ & $\sim 55 \%$ & -- & $16.8 \%$ & $2.5 \%$ & $48.5 \%$ & $0.5 \%$ & $50.2 \%$ & $0.3 \%$ & $\sim 74 \%$ & -- \\
\hline Liquid & wt \% & $17.0 \%$ & -- & $100 \%$ & -- & $10.2 \%$ & -- & $100 \%$ & -- & $33.6 \%$ & -- & $100 \%$ & -- & $100 \%$ & -- & $100 \%$ & -- \\
\hline Liquid & vol \% & $24 \%$ & -- & $100 \%$ & -- & $14 \%$ & -- & $100 \%$ & -- & $47 \%$ & -- & $100 \%$ & - & $100 \%$ & -- & $100 \%$ & -- \\
\hline
\end{tabular}

Water contents of FL from T3F-1-1 and T3F-1-3 and DDS from T3F-1-4 were estimated from a mass balance summing individual ions

Table 4: Density and liquid content of the Tank 2F samples

\begin{tabular}{|c|c|c|c|c|c|c|c|}
\hline \multirow{2}{*}{ Analyte } & \multirow{3}{*}{ Unit } & \multicolumn{2}{|c|}{ T2F-1-1 } & \multicolumn{4}{c|}{ FTF-245, 246 } \\
\cline { 3 - 8 } & & \multicolumn{2}{|c|}{ undrained saltcake } & \multicolumn{2}{|c|}{ SL (unfiltered) } & \multicolumn{2}{c|}{ SL (filtered) } \\
\cline { 3 - 8 } & average & stdev & average & stdev & average & stdev \\
\hline Density & $\mathrm{g} / \mathrm{mL}$ & 2.04 & -- & 1.50 & -- & 1.50 & 0.03 \\
\hline Water & wt \% & 6.2 & 0.6 & 47.8 & -- & 47.8 & 1.1 \\
\hline Liquid & vol \% & 18 & -- & $>99.9$ & -- & 100 & - \\
\hline
\end{tabular}

Water content of unfiltered SL based on filtered SL measurement and solids collected during filtration

Table 5. Porosity and Saturation of Saltcake Samples

\begin{tabular}{cccccc}
\hline \hline $\begin{array}{c}\text { Sample } \\
\text { ID }\end{array}$ & $\begin{array}{c}\text { Sample } \\
\text { Interval } \\
(\mathbf{f t})\end{array}$ & $\begin{array}{c}\text { Bulk } \\
\text { Density } \\
\left(\mathbf{g} / \mathbf{c m}^{3}\right)\end{array}$ & $\begin{array}{c}\text { Water } \\
\text { Content } \\
\boldsymbol{\theta}_{\mathbf{w}} \\
(\mathbf{w t} \%)\end{array}$ & $\begin{array}{c}\text { Porosity } \\
\phi(\mathbf{v o l} \%)\end{array}$ & $\begin{array}{c}\text { Saturation } \\
\mathbf{S}(\mathbf{v o l} \%)\end{array}$ \\
\hline $\mathrm{T} 2 \mathrm{~F}-1-1$ & $0-1$ & 2.04 & $6.2 \pm 0.6$ & 23 & 77 \\
\hline $\begin{array}{l}\text { T3F-1-3 } \\
\text { (Tank 3) }\end{array}$ & $1-2$ & 2.07 & $5.1 \pm 2.6$ & 19 & 76 \\
\hline $\mathrm{T} 41 \mathrm{H}$ & $1-2$ & $1.92^{\mathrm{a}}$ & $3.2^{\mathrm{a}}$ & 22 & 34 \\
\hline
\end{tabular}

Note: $\quad \theta_{\mathrm{w}}$ reported as average \pm 1 Std. Dev.

${ }^{a}$ average of results reported in Nichols, $2004 .^{5}$

An attempt was made to measure the viscosity of the Tank $2 \mathrm{~F}$ supernate sample (FTF-245 and 246) by methods reported previously. ${ }^{6}$ During preparation for analysis, the sample, which had cooled to the cell temperature of below $18^{\circ} \mathrm{C}$, exhibited viscous and non-Newtonian flow behavior. The viscosity could not be measured by the existing apparatus. 
Tank 3F Chemical and Radiological Analysis

\section{Undrained Saltcake}

Table 14 through Table 18, in the appendix, contain the characterization information for the undrained bulk saltcake. Results are reported as the average of triplicate analyses for the salt from the bottom portions of each of two samples, T3F-1-1 and T3F-1-4. A blank aqua regia dissolution sample exhibited contamination by $\mathrm{Pu}$ and $\mathrm{Am}$, indicating that the Pu and Am measurements for the saltcake samples could be biased high.

The material from the bottom of T3F-1-1 had a ${ }^{137} \mathrm{Cs}$ activity of $1.5 \mathrm{Ci} / \mathrm{gal}$ and a total alpha (based on the sum of ${ }^{238} \mathrm{Pu},{ }^{239 / 240} \mathrm{Pu}$, and ${ }^{241} \mathrm{Am}$ ) of $9.6 \mathrm{E}+3 \mathrm{pCi} / \mathrm{g}$. The material from the bottom of T3F-1-4 had a ${ }^{137} \mathrm{Cs}$ activity of $3.5 \mathrm{Ci} / \mathrm{gal}$ and a total alpha of $8.9 \mathrm{E}+3 \mathrm{pCi} / \mathrm{g}$. The higher ${ }^{137} \mathrm{Cs}$ content of T3F-1-4 correlates roughly with the higher water content, and consequently the higher interstitial liquid content, of T3F-1-4.

The average total strontium in the Tank $3 \mathrm{~F}$ samples was $2.70 \mathrm{E}-5 \mathrm{wt} \%$, of which ${ }^{90} \mathrm{Sr}$ had a $3.6 \pm 0.2$ wt \% isotopic contribution to the total strontium.

\section{Interstitial and Free Liquid}

Table 19 through Table 22, in the appendix, contain the characterization information for the supernatant free liquid (FL) decanted from each sample and the interstitial liquid (IL) drained from sample T3F-1-4. Liquids were filtered in preparation for dilution and analysis. Results are reported as the average of duplicate analyses for the liquids, with the exception of T3F-1-3 FL, which had only a single analysis.

The interstitial liquid drained from sample T3F-1-4 had a ${ }^{137} \mathrm{Cs}$ activity of $7.1 \mathrm{Ci} /$ gal. and a total ${ }^{238} \mathrm{Pu}$, ${ }^{239 / 240} \mathrm{Pu}$, and ${ }^{241} \mathrm{Am}$ activity of $1.15 \mathrm{E}+4 \mathrm{pCi} / \mathrm{mL}$. The ${ }^{137} \mathrm{Cs}$ activity in the free liquid associated with the three saltcake core samples trend higher for subsequent samples taken deeper in the tank (6.1 Ci/gal., 6.6 Ci/gal., and 7.1 Ci/gal., for T3F-1-1, T3F-1-3, and T3F-1-4, respectively). The ${ }^{137} \mathrm{Cs}$ activity and ${ }^{99}$ Tc activity in the interstitial liquid drained from T3F-1-4 match well with the free liquid associated with T3F-1-4. In general, the chemical composition of the three free liquid samples and the interstitial liquid are similar. There were much larger differences, however, in the measurement for sparingly soluble radionuclides, such as uranium, plutonium, americium, and strontium. A large variance was seen in the measured concentrations of ${ }^{238} \mathrm{Pu}$ in filtered liquid samples $(1.12 \mathrm{E}+3 \mathrm{pCi} / \mathrm{mL}$ to $6.72 \mathrm{E}+3 \mathrm{pCi} / \mathrm{mL}$ ) despite the nearly identical chemical makeup of the samples. The existence of such large variances in uranium, plutonium, and americium measurements indicate that it is unlikely that all of the samples are at their saturated equilibrium levels of these species.

\section{Comparison of Components}

Table 6, Table 7, and Table 8 contain summaries of the radiological, ionic, and elemental composition, respectively, of the undrained saltcake, the filtered free liquid (FL), the filtered interstitial liquid (IL), and the drained/dissolved saltcake (DDS). The characterization results for both the solid and the liquid streams are presented in per mass units to ease comparison and calculation. The tables are compilations of results from several separate preparations and analytical methods.

DDS values are calculated from data obtained during the dissolution tests on drained saltcake described later in this report (see Appendix Table 36 through Table 38). The DDS values in Table 6 through Table 8 are the combination of the filtered bulk dissolution sample results with addition of soluble components of the periodic sub-samples. 
The columns in Table 6 through Table 8 labeled "Partition into IL (\%)" are estimates for each component of the percentage measured in the undrained saltcake that was contained in the interstitial liquid residing in the saltcake pores. Subtracting the "Partition into IL" from $100 \%$ yields an estimate for each component of the percentage contained in the solid phase of the original saltcake sample. To calculate the value reported as the "Partition into IL" for each component, the wt \% of the component measured in the filtered interstitial liquid (drained from T3F-1-4) is multiplied by the wt \% of IL in the undrained saltcake and divided by the wt \% of the component measured in the undrained saltcake. In some cases, the value was calculated using the composition of the filtered supernate instead of the composition of the free liquid. The relative error in these calculated values is roughly $25 \%$.

The "Partition into IL" for many components is statistically indistinguishable from $100 \%$, including cesium, gross beta, nitrite, hydroxide, aluminate, and phosphate. Some components, conversely, are present in the interstitial liquid at much lower levels than in the saltcake solids, including uranium, strontium, sulfate, and iron. Several other components appear to be contained in both the interstitial liquid and the saltcake solids, including technetium, plutonium, americium, sodium, nitrate, carbonate, and chromium.

Table 7 contains several values that are calculated from several analytical techniques. The mass balance for each stream is calculated by summing the analytes in Table 7 that are above detection limits and the water content in Table 3. In the case of the free liquid in samples T3F-1-1 and T3F-1-3, water content information was unknown. The mass balance was set to $100 \%$ to estimate the free liquid water content reported in Table 3 . The charge balance for each stream is calculated by summing the normalities of the anions and dividing by the sum of the normalities of the cations. Charge balance values above $100 \%$ indicate that more anions were measured than would correspond to the cation measurement. The calculated hydroxide concentration is used to check the measured free hydroxide titration. It estimates the free hydroxide by taking the total base measured by titration and subtracting the carbonate by TIC and the aluminate by ICP-ES. Total cesium is calculated as the sum of ${ }^{133} \mathrm{Cs}$ by ICP-MS and the ${ }^{137} \mathrm{Cs}$ from rad. chem. Several other components (phosphate, sulfate, and potassium) have been measured by two equally valid analytical methods.

Of interest is the comparison of the interstitial liquid and the drained/dissolved saltcake for T3F-1-4. The compositions of these two solutions differ greatly, from the IL being a saturated solution with high hydroxide (12.9 $\mathrm{M} \mathrm{Na}^{+}, 6.8 \mathrm{M} \mathrm{OH}^{-}$) to the DDS being an unsaturated solution with low hydroxide (3.7 $\mathrm{M} \mathrm{Na}^{+}, 0.10 \mathrm{M} \mathrm{OH}^{-}$). Despite the large differences in these solution compositions, they have relatively similar levels of plutonium and americium in solution (within $\sim 30 \%$ ). The uranium content of the DDS is about twice that of the IL.

Table 9 compares the liquid streams which may be a part of those encountered during processing. The FL from the three samples and the IL form sample T3F-1-4 (converted to molarity from the values in the previous summary tables) would be similar to the material that will be removed during draining. The sample, however, corresponded to only a relatively small vertical portion near the surface of the saltcake. The composition of the liquid at a lower tank elevation may differ. Table 9 contains the direct measurement for the sample T3F-1-4 filtered drained dissolved salt (DDS) at 3.7 $\mathrm{M} \mathrm{Na}^{+}$and calculated values for the $6 \mathrm{M} \mathrm{Na}^{+}$adjusted drained dissolved salt stream (ADDS). Note that, while the directly measured DDS stream was filtered and thus contained no solids, it was likely undersaturated with respect to salt components expected during salt dissolution. The ADDS stream, however, was calculated from a stream of lower salt concentration and thus may contain some sparingly soluble components at levels above their equilibrium saturation.

The other streams contained in Table 9 are, for samples T3F-1-1 and T3F-1-4, the undrained dissolved salt (UDS-0) and the prediction for the drained dissolved salt calculated with removal of $25 \%, 50 \%$, and $100 \%$ of the interstitial liquid (DDS-25, DDS-50, and DDS-100, respectively). The interstitial liquid composition for both samples was taken as the composition of IL drained from T3F-14. The undrained dissolved salt and the predicted drained dissolved salt streams are compared at a total sodium ion concentration of $6 \mathrm{M}$. These $6 \mathrm{M}$ streams do not indicate the solubility of the 
individual components in the saltcake. The values for these dissolved salt streams contains the contribution from the solids that may be present, which would include some less soluble salts and water insoluble solids. The dissolved salt streams are average values for the complete dissolution (or slurrying) of the saltcake and do not account for selective dissolution. During dissolution processes occurring over several stages with liquid movement within the saltcake, the more soluble components, such as $\mathrm{OH}^{-}, \mathrm{NO}_{2}^{-}$, and ${ }^{137} \mathrm{Cs}$, would be more concentrated in earlier stages while less soluble components, such as $\mathrm{CO}_{3}{ }^{2-}$ and $\mathrm{SO}_{4}{ }^{2-}$, would be more concentrated in the later stages.

A comparison between the adjusted drained/dissolved salt stream (ADDS) for sample T3F-1-4 and the calculated drained/dissolved salt with $50 \%$ interstitial liquid removal (DDS-50) for T3F-1-4 shows good agreement for the composition of this (primarily) sodium nitrate solution. Heterogeneities within the original sample likely contribute to the sample compositional differences: the ADDS had higher nitrite and carbonate and lower hydroxide than did DDS-50. Because ADDS also had a lower ${ }^{137} \mathrm{Cs}$ than the calculated stream with $50 \%$ interstitial liquid removal, greater than $50 \%$ of the interstitial liquid was drained from T3F-1-4 during testing. Comparing these streams for T3F-1-4 with the similar stream (DDS-50) for T3F-1-1, it is clear that the T3F-1-1 saltcake is a purer sodium nitrate salt.

Also included in Table 9 are values for each stream indicating the grams of salt required to produce a $6 \mathrm{M} \mathrm{Na}^{+}$solution. An estimate of the amount of sludge that could be contained in the dissolved salt solutions is estimated from the concentration of iron, chromium, barium, manganese, and nickel in the saltcake. The estimate does not contain contributions by silicon, aluminum, and radionuclides. The composition of the sludge used in the estimates are approximately $65 \mathrm{wt} \% \mathrm{Fe}(\mathrm{OH})_{3}, 27 \mathrm{wt} \%$ $\mathrm{Cr}(\mathrm{OH})_{3}, 5 \mathrm{wt} \% \mathrm{BaSO}_{4}$, and $3 \mathrm{wt} \% \mathrm{MnO}_{2}$ for T3F-1-1 and $62 \mathrm{wt} \% \mathrm{Fe}(\mathrm{OH})_{3}, 31 \mathrm{wt} \% \mathrm{Cr}(\mathrm{OH})_{3}, 6 \mathrm{wt}$ $\% \mathrm{Ni}(\mathrm{OH})_{2}$, and $1 \mathrm{wt} \% \mathrm{BaSO}_{4}$ for T3F-1-4. Compared to other saltcake samples, there is a relatively large amount of insoluble chromium evident in Tank 3F. This high quantity of chromium may be the origin of the light violet color of the free liquid. Many $\mathrm{Cr}(\mathrm{III})$ compounds are violet, although the solubility of $\mathrm{Cr}(\mathrm{III})$ in this strongly alkaline solution is likely very low. Further spectral analysis would be needed to identify the cause of the solution color.

Figure 13 and appendix Table 23 indicate the likely composition of the solid phase in the original undrained sample. This composition is formulated from the major components of saltcake in which all interstitial liquid has been removed. The removal of interstitial liquid is done by calculation in a similar manner to the formulation of DDS-100: Information on the original percentage interstitial liquid in the undrained saltcake is used to adjust the bulk saltcake composition by subtracting out the contribution of the interstitial liquid. Finally, the saltcake composition is normalized to sum to $100 \mathrm{wt} \%$. The unnormalized composition summed to only $97 \mathrm{wt} \%$ for T3F-1-1 and $87 \mathrm{wt} \%$ for T3F-1-4. 
Table 6: Summary of Radiological Composition of Tank 3F Samples

\begin{tabular}{|c|c|c|c|c|c|c|c|c|c|c|c|c|c|c|c|c|c|c|c|c|c|c|c|c|c|}
\hline & 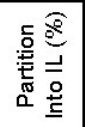 & 1 & $F$ & $\sqrt{N}$ & 2 & 怘 & 11 & 1 & i & & in & 1 & 1 & 10 & 垔 & $\stackrel{ \pm}{N}$ & 1 & i & 1 & ผ & 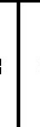 & న్ & & $\infty$ & 1 \\
\hline & 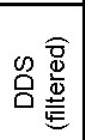 & & $\mid$ & 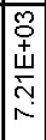 & 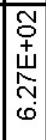 & 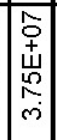 & $\begin{array}{c} \\
\\
+ \\
\dot{+} \\
\dot{+} \\
v \\
v\end{array}$ & 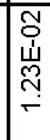 & 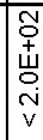 & 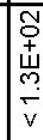 & 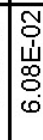 & \begin{tabular}{|c|} 
\\
\\
$⿱ 亠 䒑$ \\
$⿱ 亠 䒑$ \\
$\vdots$ \\
$\frac{11}{v}$ \\
\end{tabular} & 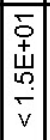 & 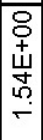 & 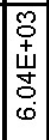 & 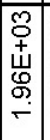 & 嵌 & 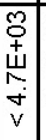 & 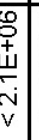 & 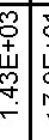 & & i & & | & \\
\hline & 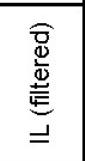 & 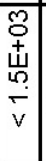 & 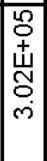 & . & 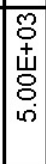 & 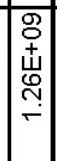 & 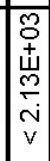 & 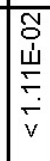 & 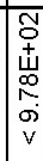 & 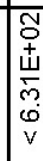 & 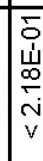 & 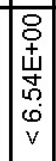 & 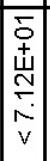 & 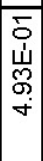 & \begin{tabular}{|l|} 
\\
\\
+ \\
$\dot{+}$ \\
$\dot{\omega}$ \\
$\dot{\sim}$ \\
$\dot{\forall}$ \\
\end{tabular} & 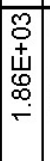 & 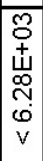 & 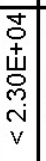 & $\begin{array}{l} \\
0 \\
+ \\
\\
0 \\
\\
v\end{array}$ & $\begin{array}{l} \\
\\
+ \\
\\
m \\
\\
\end{array}$ & & 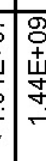 & & 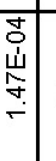 & \\
\hline & 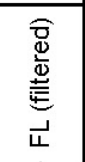 & 1 & 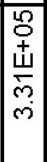 & 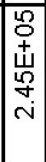 & 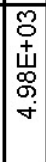 & 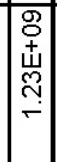 & 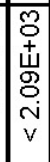 & 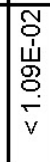 & 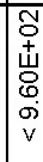 & 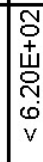 & $\begin{array}{l}\bar{D} \\
\dot{\mathcal{U}} \\
\dot{v} \\
\grave{v} \\
\mathrm{v}\end{array}$ & \begin{tabular}{|c|} 
\\
\\
$\dot{+}$ \\
$\underset{+}{+}$ \\
$\dot{6}$ \\
$v$ \\
\end{tabular} & \begin{tabular}{|c|}
$\overline{0}$ \\
$\dot{+}$ \\
$\dot{S}$ \\
$\sigma$ \\
$\dot{6}$ \\
$\mathrm{v}$ \\
\end{tabular} & 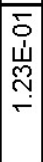 & 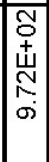 & 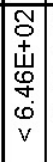 & 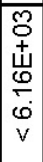 & 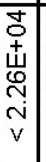 & 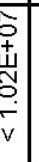 & 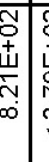 & co & 岁 & & & \\
\hline & & 1 & 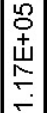 & 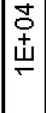 & \begin{tabular}{l}
$\mathbf{O}$ \\
+ \\
\multirow{4}{N}{} \\
\end{tabular} & 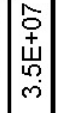 & 1 & 1 & I & I & 总 & 1 & 1 & 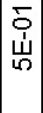 & 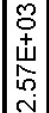 & \begin{tabular}{|l|} 
\\
0 \\
+ \\
$\stackrel{+}{\sim}$ \\
\\
\end{tabular} & I & ! & I & 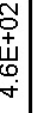 & & . & & 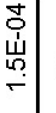 & 1 \\
\hline & 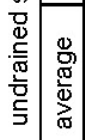 & 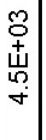 & 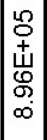 & 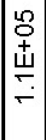 & 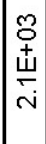 & 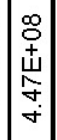 & $\begin{array}{c}m \\
0 \\
\dot{+} \\
\dot{+} \\
\dot{v} \\
v\end{array}$ & 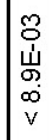 & & 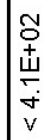 & & $\left|\begin{array}{c}\stackrel{8}{+} \\
\stackrel{+}{\sim} \\
\dot{\sim} \\
v\end{array}\right|$ & 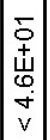 & $\begin{array}{l}8 \\
\stackrel{8}{+} \\
\dot{+} \\
\dot{\sigma} \\
\dot{m}\end{array}$ & 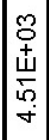 & 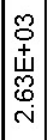 & 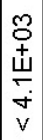 & 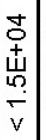 & 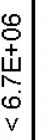 & 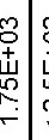 & & $\begin{array}{l}\infty \\
\stackrel{+}{+} \\
\stackrel{+}{\$} \\
\text { ஸे }\end{array}$ & & 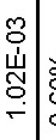 & \\
\hline$p$ & 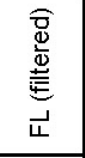 & 11 & $\mid$ & 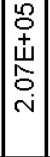 & 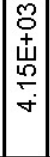 & 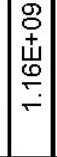 & 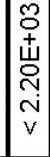 & 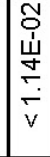 & 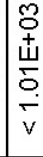 & 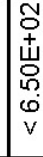 & 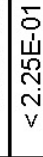 & 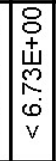 & 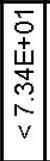 & 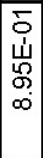 & 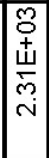 & 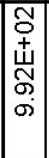 & 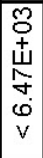 & 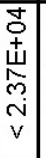 & 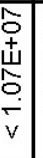 & | & 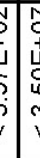 & 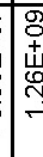 & 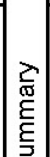 & 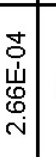 & \\
\hline & 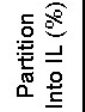 & 1 & $m$ & g & 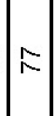 & $\frac{F}{\div}$ & i & 1 & I & i & $\stackrel{g}{\mathrm{v}}$ & 1 & 1 & $\stackrel{+}{\sim}$ & $\stackrel{m}{\div}$ & $m$ & i & I & 1 & ? & 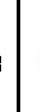 & $\stackrel{\infty}{\circ}$ & $\mid \underline{\Xi}$ & $\stackrel{+}{\leftarrow}$ & I \\
\hline $\bar{T}$ & 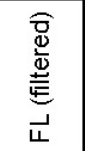 & & 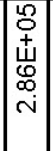 & 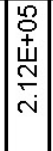 & 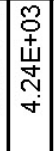 & 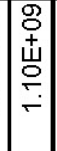 & 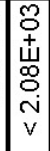 & 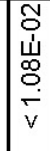 & 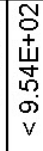 & 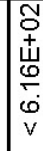 & $\begin{array}{l}\bar{\Sigma} \\
\stackrel{\bar{u}}{\mathrm{~m}} \\
\stackrel{\mathrm{j}}{\mathrm{j}} \\
\mathrm{v}\end{array}$ & 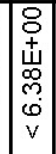 & 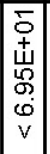 & 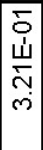 & 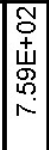 & 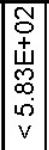 & $\mid$\begin{tabular}{|c|}
0 \\
+ \\
$\omega$ \\
0 \\
0 \\
0
\end{tabular} & 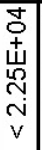 & \begin{tabular}{|l|} 
\\
\\
+ \\
\\
0 \\
\\
$v$ \\
\end{tabular} & 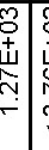 & & 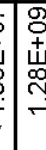 & & 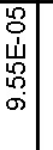 & \\
\hline & 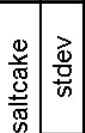 & 1 & 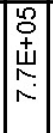 & 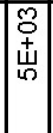 & 总 & 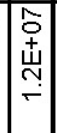 & 1 & 1 & I & i & 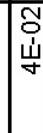 & 1 & 1 & 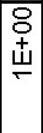 & 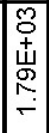 & 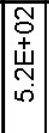 & i & 1 & 1 & ك. & & $\infty$ & & 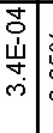 & 0 \\
\hline & 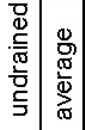 & 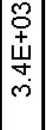 & 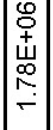 & $\mid \begin{array}{l}0 \\
0 \\
⿱ 亠 䒑 \\
\omega \\
\omega \\
\infty \\
\infty\end{array}$ & $\mid \begin{array}{c}\stackrel{\rho}{+} \\
\stackrel{+}{\uplus} \\
\dot{r}\end{array}$ & 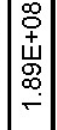 & $\mid \begin{array}{c}\stackrel{3}{o} \\
+ \\
\stackrel{+}{\Psi} \\
\dot{v} \\
v\end{array}$ & 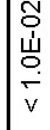 & 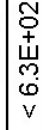 & 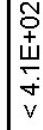 & 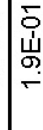 & 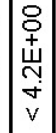 & 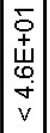 & 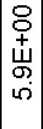 & 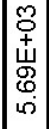 & 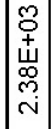 & 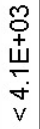 & 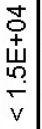 & $\begin{array}{l}0 \\
\vdots \\
1 \\
0 \\
v \\
v\end{array}$ & 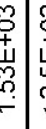 & & $\begin{array}{l}\infty \\
\stackrel{+}{+} \\
\stackrel{4}{0} \\
\end{array}$ & & 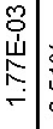 & 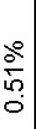 \\
\hline & 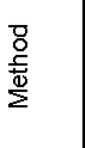 & 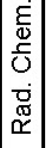 & 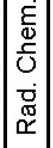 & $\mid \begin{array}{l}0 \\
\sum \\
\underline{1} \\
\underline{0} \\
-\end{array}$ & $\begin{array}{l}\sum_{1}^{0} \\
0 \\
\underline{0} \\
\underline{0} \\
\end{array}$ & 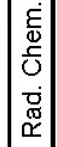 & $\begin{array}{l}\sum_{1} \\
\underline{1} \\
\underline{0} \\
\end{array}$ & 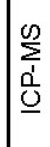 & $\begin{array}{l}\sum_{0}^{0} \\
\text { di } \\
\underline{0} \\
\end{array}$ & 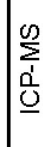 & $\begin{array}{l}\sum_{i}^{0} \\
\underline{0} \\
\underline{0}\end{array}$ & 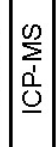 & $\left|\begin{array}{l}0 \\
\sum_{1}^{\prime} \\
0 \\
\underline{0}\end{array}\right|$ & $\begin{array}{l}0 \\
\sum_{1} \\
\underline{1} \\
\underline{0}\end{array}$ & 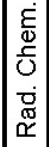 & 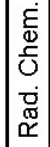 & $\stackrel{0}{\Sigma}$ & $\begin{array}{l}0 \\
\sum \\
\text { 1 } \\
\underline{0}\end{array}$ & $\sum_{0}^{\infty}$ & 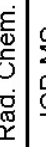 & & 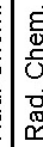 & & & $\underline{\underline{v}}$ \\
\hline & $\frac{\stackrel{n}{5}}{5}$ & 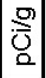 & 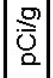 & $\mid \begin{array}{l}0 \\
\overline{0} \\
0\end{array}$ & $\frac{9}{0}$ & $\frac{0}{0}$ & 10 & $\frac{9}{0}$ & 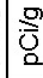 & $\frac{9}{0}$ & 음 & 号 & $\mid \begin{array}{l}\text { 웜 } \\
\overline{0}\end{array}$ & $\begin{array}{l}\text { O } \\
0 \\
0\end{array}$ & $\begin{array}{l}9 \\
\overline{0} \\
0\end{array}$ & $\frac{9}{0}$ & & $\begin{array}{l}\text { : } \\
0 \\
0\end{array}$ & 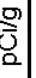 & 䍖 & & 1 & & \begin{tabular}{l}
$\circ$ \\
\multirow{3}{*}{}
\end{tabular} & $\stackrel{\circ}{\stackrel{0}{\xi}}$ \\
\hline & 离 & & & & 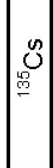 & $\mid \begin{array}{c}0 \\
0 \\
0 \\
0\end{array}$ & 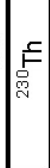 & F & & ج్ & Sh & 氕 & 2 & ح) & ฉू & $\stackrel{a}{g}$ & & व & & 东 & & & & $\begin{array}{l}\frac{\partial}{\bar{\Phi}} \\
\text { 응 }\end{array}$ & \\
\hline
\end{tabular}


Table 7: Summary of lonic Composition of Tank 3F Samples

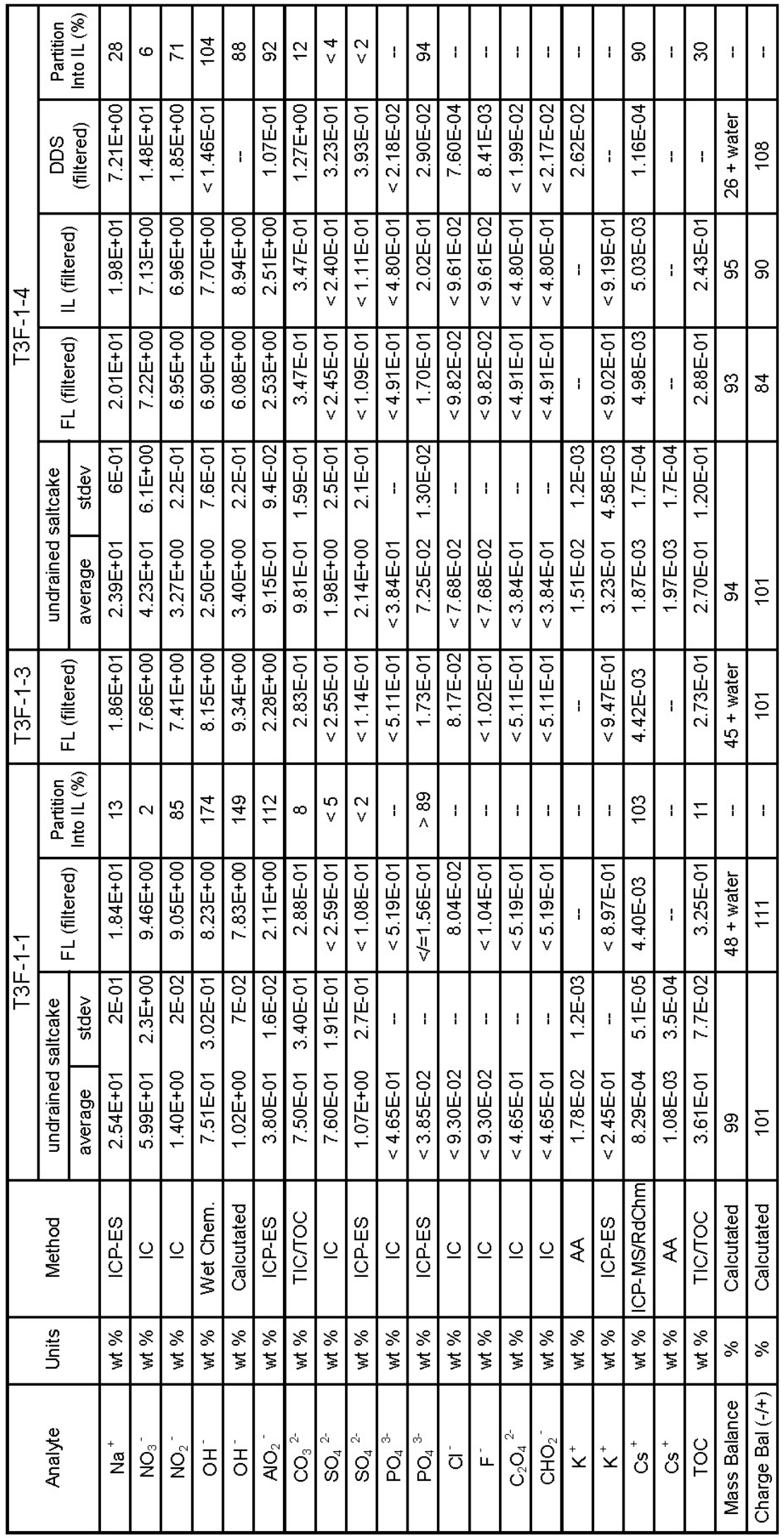


WSRC-TR-2004-00131

Revision 0

Table 8: Summary of Other Elemental Composition of Tank 3F Samples

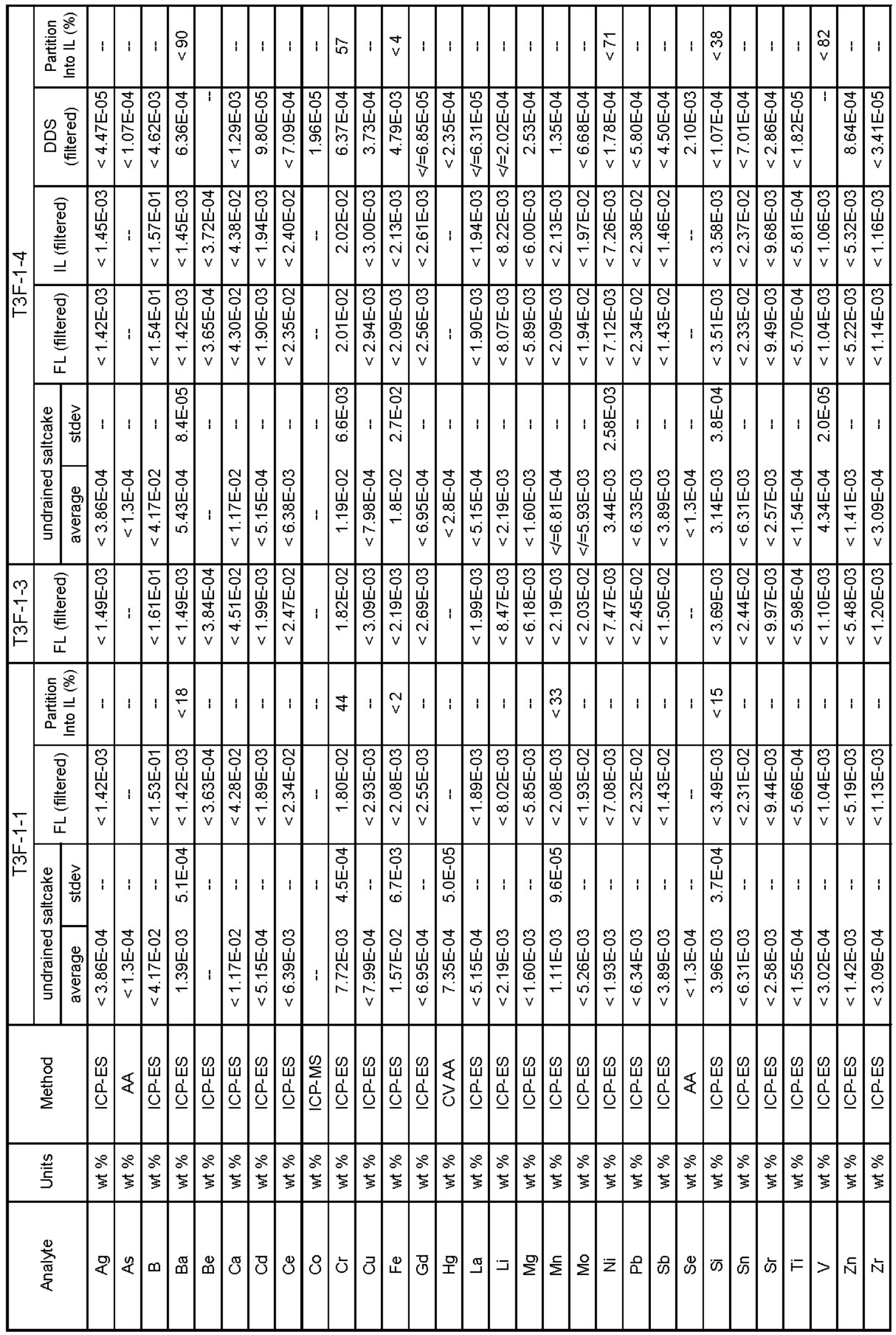


Table 9: Potential Streams During Draining and Dissolution of Tank 3F Saltcake

\begin{tabular}{|c|c|c|c|c|c|c|c|c|c|c|c|c|c|c|c|c|c|c|c|c|c|c|c|c|}
\hline 菅 & $\left|\begin{array}{c}8 \\
0\end{array}\right|$ & $\underset{i s}{\stackrel{\nabla}{\sigma}}$ & $\stackrel{\varphi}{0}$ & 10 & $\frac{\sigma}{\circ}$ & 음 & $\frac{N}{0}$ & $\mathrm{i}$ & i & ; & 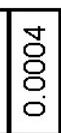 & $:$ & $:$ & ; & i & $\begin{array}{l} \\
\\
\\
\circ \\
\circ\end{array}$ & $\begin{array}{l}8 \\
\\
\\
0\end{array}$ & i & 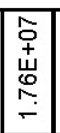 & 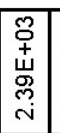 & 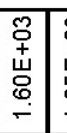 & 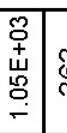 & & \\
\hline $\begin{array}{l}\text { * } \\
\text { 总 } \\
0 \\
0 \\
0 \\
0\end{array}$ & $\left|\begin{array}{l}8 \\
0 \\
0\end{array}\right|$ & 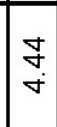 & $\begin{array}{l}\bar{m} \\
\stackrel{\circ}{\circ}\end{array}$ & f & $\mid \begin{array}{l}\frac{2}{2} \\
0 \\
0\end{array}$ & \begin{tabular}{|l}
0 \\
0 \\
0 \\
0 \\
0 \\
0
\end{tabular} & 웅 & $i$ & i & : & 응 & $:$ & : & ; & i & \begin{tabular}{|l|} 
\\
$\dot{m}$ \\
\\
$\circ$ \\
\end{tabular} & 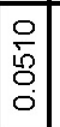 & $\mathrm{i}$ & 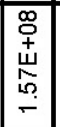 & 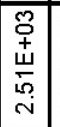 & 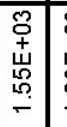 & 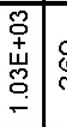 & ஜ্ল & \\
\hline \begin{tabular}{l}
\multirow{2}{*}{} \\
N. \\
0 \\
0 \\
0 \\
\end{tabular} & $\left|\begin{array}{l}8 \\
0 \\
0\end{array}\right|$ & $\underset{f}{f}$ & $\begin{array}{l}0 \\
0 \\
0 \\
0\end{array}$ & $\begin{array}{l}0 \\
0 \\
0\end{array}$ & à & $\mid \begin{array}{c}0 \\
\vdots \\
0\end{array}$ & $\stackrel{0}{\circ}$ & $i$ & $i$ & I & \begin{tabular}{|l|} 
\\
$\overline{\tilde{z}}$ \\
$\overline{0}$ \\
$\dot{0}$ \\
\end{tabular} & $i$ & $i$ & $:$ & : & \begin{tabular}{|l|}
$\infty$ \\
\\
\\
\\
\end{tabular} & $\begin{array}{l}0 \\
8 \\
8 \\
0 \\
\end{array}$ & $\mathrm{i}$ & 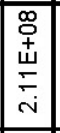 & 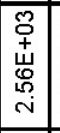 & 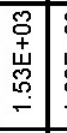 & 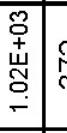 & Nָ & مْ \\
\hline 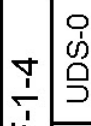 & $\left|\begin{array}{l}8 \\
0\end{array}\right|$ & 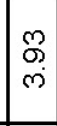 & $\mid \begin{array}{c}- \\
\dot{\sigma} \\
0\end{array}$ & $\begin{array}{l}2 \\
\infty \\
0 \\
0\end{array}$ & $\stackrel{\stackrel{L}{?}}{\leftarrow}$ & \begin{tabular}{|l|l}
$\mathscr{2}$ \\
0 \\
0 \\
0
\end{tabular} & $\begin{array}{l}8 \\
\\
0\end{array}$ & $\frac{9}{\sigma}$ & 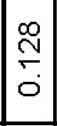 & & \begin{tabular}{|l|} 
\\
8 \\
0 \\
0 \\
\end{tabular} & i & i & i & i & 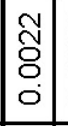 & $\begin{array}{l}8 \\
0 \\
0 \\
0 \\
0\end{array}$ & $\begin{array}{l}\text { D. } \\
0 \\
0 \\
0 \\
\end{array}$ & 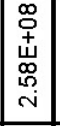 & 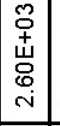 & 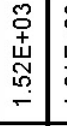 & 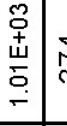 & N & \\
\hline 岕 & $\begin{array}{l}8 \\
0 \\
0\end{array} \mid$ & \begin{tabular}{l}
0 \\
$\stackrel{0}{0}$ \\
+ \\
\hdashline
\end{tabular} & $\hat{\circ}$ & 告 & i & \begin{tabular}{|l|} 
\\
0 \\
0 \\
0 \\
0
\end{tabular} & $\begin{array}{l}\mathcal{P} \\
\stackrel{0}{0} \\
\end{array}$ & 要 & 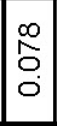 & \begin{tabular}{|l}
8 \\
\\
0 \\
0
\end{tabular} & 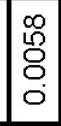 & \begin{tabular}{|l|}
$\overline{0}$ \\
\\
\\
0 \\
\end{tabular} & \begin{tabular}{|l|} 
\\
$\infty$ \\
8 \\
0 \\
0 \\
\end{tabular} & \begin{tabular}{|l|} 
\\
\\
\\
\\
\end{tabular} & 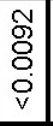 & \begin{tabular}{|l|}
$\stackrel{\infty}{N}$ \\
$\stackrel{N}{0}$ \\
$\dot{0}$ \\
\end{tabular} & 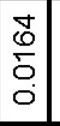 & $i$ & 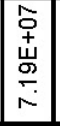 & 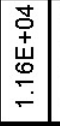 & 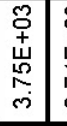 & 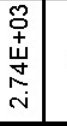 & 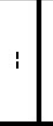 & \\
\hline 号 & $\left|\begin{array}{l}\tilde{\rho} \\
\tilde{m}\end{array}\right|$ & $\begin{array}{l}m \\
\infty \\
\sim \\
\sim\end{array}$ & 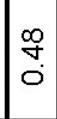 & $\frac{\sigma}{0}$ & i & $\begin{array}{l}\mathcal{N} \\
\stackrel{O}{0} \\
\end{array}$ & $\stackrel{\stackrel{\sim}{N}}{\stackrel{\circ}{\circ}}$ & $\begin{array}{l}\text { O } \\
\text { O } \\
\\
\end{array}$ & \begin{tabular}{|l|} 
\\
\\
\\
\end{tabular} & స్ & 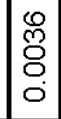 & 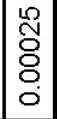 & 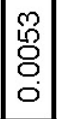 & 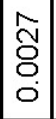 & $\begin{array}{l}0 \\
0 \\
0 \\
0 \\
0\end{array}$ & 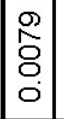 & $\begin{array}{l}\tilde{\delta} \\
\vdots \\
\\
\circ\end{array}$ & : & \begin{tabular}{|c|} 
\\
0 \\
+ \\
亗 \\
+ \\
$\dot{v}$ \\
\end{tabular} & 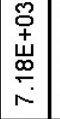 & 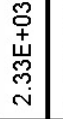 & 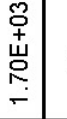 & & \\
\hline 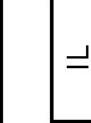 & $\begin{array}{l}\infty \\
\infty \\
\stackrel{\infty}{\leftarrow} \\
\stackrel{-}{-}\end{array}$ & $\stackrel{N}{\stackrel{r}{-}}$ & $\begin{array}{l}\stackrel{\mathscr{N}}{N} \\
\stackrel{N}{N}\end{array}$ & \begin{tabular}{|l}
0 \\
0 \\
0
\end{tabular} & 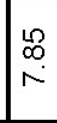 & $\begin{array}{l}\text { J } \\
\vdots \\
0 \\
\end{array}$ & \begin{tabular}{|l|}
0 \\
0 \\
0 \\
0 \\
\end{tabular} & 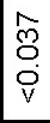 & $\begin{array}{l}\hat{N} \\
\overline{0} \\
\dot{i} \\
\mathrm{v}\end{array}$ & 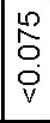 & $\begin{array}{l}\tilde{\tilde{D}} \\
\overline{0} \\
\dot{0}\end{array}$ & $\begin{array}{l} \\
\\
\\
\dot{v} \\
\end{array}$ & 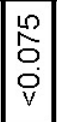 & \begin{tabular}{|l|}
$\bar{\infty}$ \\
0 \\
0 \\
$\dot{0}$ \\
$\mathrm{v}$
\end{tabular} & $\begin{array}{l}\stackrel{0}{\circ} \\
\stackrel{\circ}{\circ} \\
\mathrm{v}\end{array}$ & : & $\begin{array}{l}0 \\
\stackrel{0}{0} \\
0 \\
0\end{array}$ & ; & 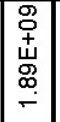 & 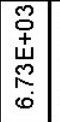 & 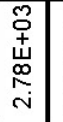 & 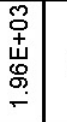 & & \\
\hline$\vec{u}$ & 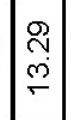 & $\stackrel{ }{\stackrel{N}{2}}$ & $\begin{array}{l}\stackrel{\rho}{m} \\
\text { in }\end{array}$ & $\frac{\infty}{\check{\omega}}$ & $\mid \begin{array}{l}8 \\
\dot{0} \\
\text { in }\end{array}$ & \begin{tabular}{|l|l} 
\\
0 \\
0 \\
0
\end{tabular} & \begin{tabular}{|l|}
$\infty$ \\
$\infty$ \\
0 \\
0 \\
0
\end{tabular} & 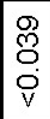 & 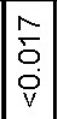 & $\begin{array}{l}0 \\
\stackrel{9}{0} \\
0 \\
0 \\
0 \\
V\end{array}$ & $\begin{array}{l}\hat{N} \\
0 \\
0 \\
0\end{array}$ & \begin{tabular}{l|} 
\\
\\
\\
\\
$V$
\end{tabular} & \begin{tabular}{|l|} 
\\
\\
0 \\
0 \\
$\mathrm{v}$ \\
$\mathrm{V}$
\end{tabular} & \begin{tabular}{|l|} 
\\
$\infty$ \\
0 \\
0 \\
0 \\
$V$
\end{tabular} & 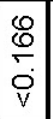 & : & $\begin{array}{l}\overline{0} \\
0 \\
0 \\
0\end{array}$ & ; & 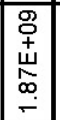 & 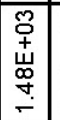 & 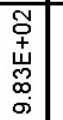 & 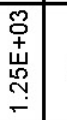 & & \\
\hline 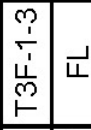 & $\left|\begin{array}{c}\frac{v}{\mathrm{~N}} \\
\stackrel{\mathrm{N}}{*}\end{array}\right|$ & $\stackrel{\substack{\infty \\
\infty}}{-}$ & 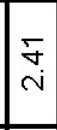 & $\stackrel{\infty}{i}$ & $\mid \begin{array}{l}\mathcal{N} \\
\infty \\
\infty\end{array}$ & $\mid \begin{array}{l}\infty \\
0 \\
0 \\
0 \\
0\end{array}$ & \begin{tabular}{|l|} 
\\
\\
0 \\
0
\end{tabular} & $\begin{array}{l} \\
\\
\\
\\
\dot{v} \\
\end{array}$ & \begin{tabular}{|l|} 
\\
\\
\\
\\
$\dot{v}$ \\
\end{tabular} & \begin{tabular}{|l}
$\bar{\infty}$ \\
0 \\
0 \\
0 \\
$\mathrm{~V}$
\end{tabular} & 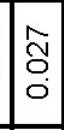 & \begin{tabular}{|l|} 
\\
\\
0 \\
0 \\
0 \\
\end{tabular} & 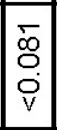 & \begin{tabular}{|l|} 
\\
0 \\
$O$ \\
0 \\
$\dot{0}$ \\
\end{tabular} & $\begin{array}{l}\stackrel{P}{\rho} \\
\frac{1}{0} \\
\mathrm{v}\end{array}$ & i & 宆 & $:$ & 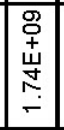 & 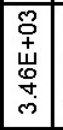 & 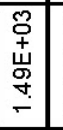 & 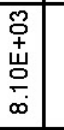 & & \\
\hline 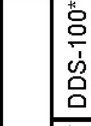 & $\mid \begin{array}{l}8 \\
0 \\
0\end{array}$ & \begin{tabular}{|l} 
के \\
ம்
\end{tabular} & 要 & 0 & 10 & 0 & 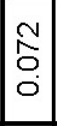 & i & i & ' & \% & i & : & $i$ & $:$ & 10 & 0 & $\mathrm{i}$ & 10 & 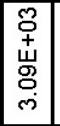 & 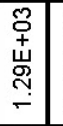 & 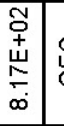 & $\begin{array}{l}\text { 吕 } \\
\text { N }\end{array}$ & \\
\hline $\begin{array}{l}\text { 菖 } \\
0 \\
0 \\
0 \\
0 \\
0\end{array}$ & $\left|\begin{array}{c}8 \\
0 \\
0\end{array}\right|$ & $\begin{array}{l}\hat{L} \\
0 \\
0 \\
0\end{array}$ & $\frac{0}{\circ}$ & 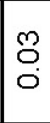 & \&. & $\begin{array}{l}0 \\
\\
0 \\
0\end{array}$ & 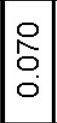 & 1 & i & i & 朵 & $i$ & $i$ & i & i & \begin{tabular}{|l|}
$\frac{m}{8}$ \\
\\
\\
\end{tabular} & $\stackrel{5}{\circ}$ & $\mathrm{i}$ & 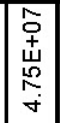 & 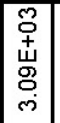 & 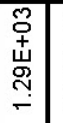 & 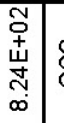 & 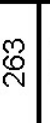 & है \\
\hline 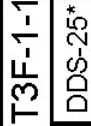 & $\begin{array}{l}8 \\
0 \\
0\end{array}$ & $\begin{array}{l}\bar{\tau} \\
\dot{\sigma}\end{array}$ & $\frac{m}{\leftarrow}$ & $\frac{0}{0}$ & $\underset{\grave{N}}{\grave{O}}$ & 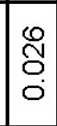 & \begin{tabular}{l|}
$\mathscr{8}$ \\
\hdashline \\
\\
\end{tabular} & ; & ; & i & ${ }_{0}^{\infty}$ & 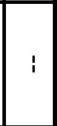 & 1 & i & i & \begin{tabular}{|l|}
$\frac{0}{8}$ \\
\\
0 \\
\end{tabular} & 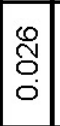 & : & 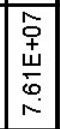 & 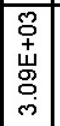 & 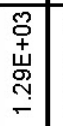 & 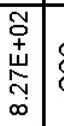 & $\stackrel{\square}{\mathrm{N}}$ & \\
\hline $\begin{array}{l}\text { 웅 } \\
0 \\
0 \\
0\end{array}$ & $\left|\begin{array}{l}8 \\
0 \\
0\end{array}\right|$ & 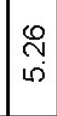 & $\frac{\varphi}{\circ}$ & 离 & m. & 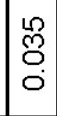 & \begin{tabular}{|l|}
$\infty$ \\
\hdashline \\
\hdashline \\
\hdashline
\end{tabular} & $\begin{array}{l}m \\
\text { Oे } \\
\\
\end{array}$ & $\begin{array}{l}\overline{8} \\
\\
\end{array}$ & : & ָิ & i & i & ' & i & 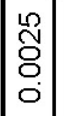 & 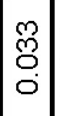 & $\begin{array}{l}\mathscr{m} \\
\stackrel{9}{O} \\
\stackrel{0}{0}\end{array}$ & 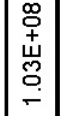 & 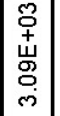 & 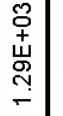 & $\begin{array}{c}\tilde{O} \\
+ \\
\text {. } \\
\tilde{m} \\
\infty\end{array}$ & $\stackrel{8}{\stackrel{8}{N}}$ & \\
\hline$\vec{u}$ & $\begin{array}{l}\infty \\
\stackrel{\infty}{-} \\
\leftarrow \\
-\end{array}$ & $\stackrel{\stackrel{\sim}{\sim}}{\mathrm{N}}$ & $\stackrel{8}{\stackrel{8}{*}}$ & $\frac{\sigma}{i}$ & $\mid \begin{array}{l}2 \\
0 \\
6\end{array}$ & 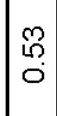 & 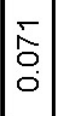 & $\begin{array}{l}\text { O } \\
\text { O } \\
\text { Q } \\
\text { v }\end{array}$ & 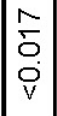 & $\begin{array}{l}\bar{\infty} \\
0 \\
\dot{0} \\
\mathrm{v}\end{array}$ & 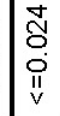 & $\begin{array}{l}m \\
\stackrel{m}{0} \\
\stackrel{0}{0}\end{array}$ & 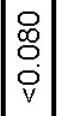 & $\begin{array}{l}1 \\
\dot{\infty} \\
0 \\
0 \\
\dot{v}\end{array}$ & $\begin{array}{l}R \\
\stackrel{R}{0} \\
\dot{0} \\
\mathrm{v}\end{array}$ & : & 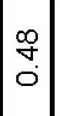 & : & 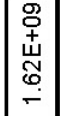 & 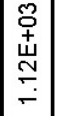 & 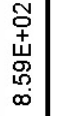 & 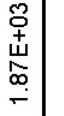 & & \\
\hline 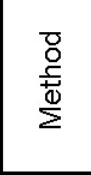 & 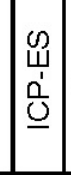 & $\underline{u}$ & $\underline{\underline{u}}$ & $\begin{array}{l}\dot{E} \\
0 \\
0 \\
0 \\
0 \\
0 \\
3\end{array}$ & 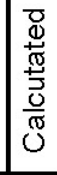 & \begin{tabular}{|l|}
$\omega$ \\
$\underline{u}$ \\
$\underline{\Lambda}$ \\
$\underline{\underline{u}}$
\end{tabular} & \begin{tabular}{|l|} 
\\
0 \\
$\frac{O}{5}$ \\
$\frac{\mathrm{O}}{1}$ \\
\end{tabular} & $\underline{\underline{U}}$ & \begin{tabular}{|l|}
$\underline{u}$ \\
$\underline{1}$ \\
$\underline{\underline{u}}$ \\
$\underline{y}$
\end{tabular} & $\underline{\underline{0}}$ & $\begin{array}{l}\underline{\mu} \\
\underline{u} \\
\underline{0} \\
\underline{0}\end{array}$ & $\underline{U}$ & $\underline{0}$ & $\underline{U}$ & $\underline{0}$ & 委 & 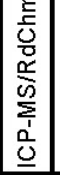 & $\frac{\pi}{x}$ & 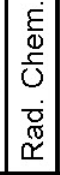 & 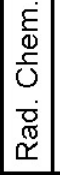 & $\begin{array}{c}\dot{\varepsilon} \\
0 \\
\frac{0}{U} \\
\dot{0} \\
\dot{\sigma} \\
\widetilde{\Sigma} \\
\end{array}$ & 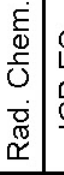 & 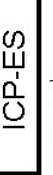 & \\
\hline & $\Sigma$ & $\Sigma$ & $\Sigma$ & $\Sigma$ & $\Sigma$ & $\Sigma$ & $\Sigma$ & $\Sigma$ & $\Sigma$ & $\Sigma$ & $\Sigma$ & $\Sigma$ & $\Sigma$ & $\Sigma$ & $\Sigma$ & $\Sigma$ & $\sum_{\xi}$ & $\sum_{\xi}$ & $\mid$\begin{tabular}{|l}
$\vec{\xi}$ \\
음
\end{tabular} & \begin{tabular}{|l}
$\vec{\xi}$ \\
음
\end{tabular} & $\overrightarrow{\underline{\partial}}$ & $\vec{\xi}$ & छे & \\
\hline $\begin{array}{l}\frac{0}{2} \\
\frac{5}{\mathbb{N}} \\
\frac{1}{\alpha}\end{array}$ & $\stackrel{\pi}{2}$ & 乏 & 号 & & I & $\frac{\mathrm{O}}{\mathrm{x}}$ & $8^{m}$ & & \begin{tabular}{l} 
\\
\hdashline \\
\hdashline
\end{tabular} & 0 & $\begin{array}{l}0^{+} \\
0^{\circ}\end{array}$ & $\overline{\mathrm{U}}$ & ४ & $\mid \begin{array}{l}0 \\
0 \\
0 \\
0\end{array}$ & 0 & $\checkmark$ & on & & $\begin{array}{l}0 \\
0 \\
0 \\
0 \\
c\end{array}$ & 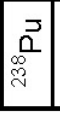 & 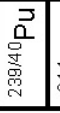 & 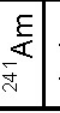 & $\begin{array}{l}\frac{0}{0} \\
\frac{7}{2}\end{array}$ & \\
\hline
\end{tabular}



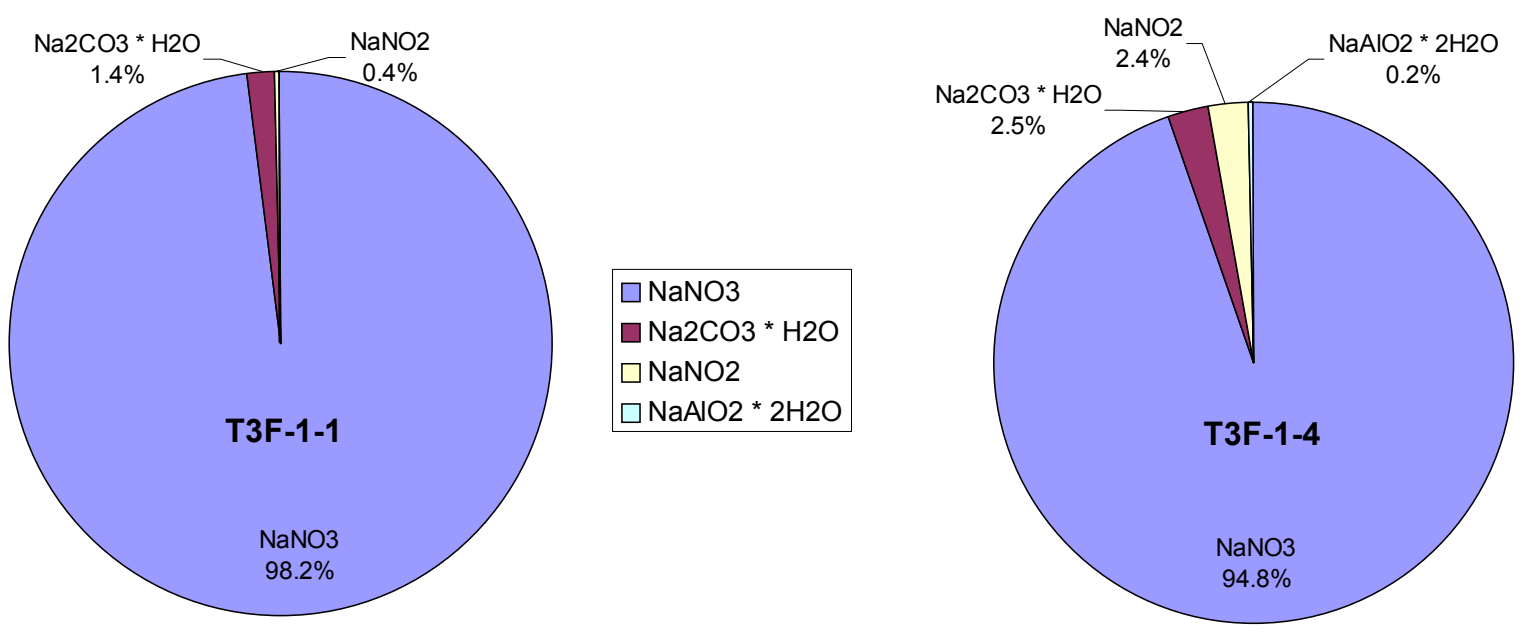

Figure 13: Likely major components of Tank 3F salt solids, normalized to $100 \mathrm{wt} \%$

\section{$\underline{\text { Tank 2F Chemical and Radiological Analysis }}$}

\section{Undrained Saltcake}

Table 24 through Table 28, in the appendix, contain the characterization information for the undrained bulk saltcake from the bottom of the top portion of T2F-1-1. Results are reported as the average of triplicate analyses. The ${ }^{137} \mathrm{Cs}$ activity of the sample was $9.70 \mathrm{E}+7 \mathrm{pCi} / \mathrm{g}$, which corresponds to $0.75 \mathrm{Ci}$ per gallon of saltcake. Note that this relatively low ${ }^{137} \mathrm{Cs}$ activity is encountered in a sample that has a relatively low liquid content. The activities of measured alpha-emitting isotopes $\left({ }^{238} \mathrm{Pu},{ }^{239 / 240} \mathrm{Pu}\right.$, and ${ }^{241} \mathrm{Am}$ ) sum to $2.1 \mathrm{E}+4 \mathrm{pCi} / \mathrm{g}$. Based on the ICP-MS value for ${ }^{88} \mathrm{Sr}$ and the rad. chem. value for ${ }^{90} \mathrm{Sr}$, the total $\mathrm{Sr}$ in sample T2F-1-1 is $2.88 \mathrm{E}-5 \mathrm{wt} \%$, of which ${ }^{90} \mathrm{Sr}$ has a $3.3 \mathrm{wt} \%$ isotopic contribution to the total $\mathrm{Sr}$. The quantity and isotopic distribution of strontium in T2F-1-1 are very similar to that of T3F-1-1 and T3F-1-4.

\section{Supernatant Liquid}

Table 29 through Table 33, in the appendix, contain the initial data from the analysis of the Tank 2F samples (FTF-245 and 246). The average and standard deviation of duplicate analyses of a single diluted sample are provided. The ${ }^{137} \mathrm{Cs}$ activity of the as-received and the filtered Tank $2 \mathrm{~F}$ supernate samples were $1.64 \mathrm{E}+9 \mathrm{pCi} / \mathrm{mL}$, which corresponds to $6.2 \mathrm{Ci} / \mathrm{gal}$. The $\mathrm{Pu}$ and $\mathrm{Am}$ isotopes of interest were below the detection limit.

\section{Comparison of Components}

Table 10, Table 11, and Table 12 contain summaries of the radiological, ionic, and elemental composition, respectively, of the undrained saltcake and the unfiltered and filtered supernatant liquid (SL) samples. (See the discussion of the Tank 3F comparison tables for details.) Because no separate interstitial analysis was available for Tank $2 \mathrm{~F}$, the SL samples were assumed to approximate the IL and were used for the calculations.

For the "Partition into IL" for the Tank 2F samples, it appears that cesium, technetium, potassium, and phosphate are partitioned into the original interstitial liquid, but there is a large departure from $100 \%$. 
Also, some components that are usually observed to be in the interstitial liquid (including nitrite, hydroxide, and aluminate) were not for the Tank $2 \mathrm{~F}$ sample analysis. It is concluded that the assumption that IL and SL are comparable leads to poor material balances for these samples. As with Tank 3F, some components appear to be present in the Tank $2 \mathrm{~F} \mathrm{IL}$ at much lower levels than in the saltcake solids, including uranium, plutonium, americium, strontium, sulfate, carbonate, oxalate, iron, barium, cobalt, manganese, and ${ }^{14} \mathrm{C}$.

Table 13 contains the comparison of the liquid streams which are projected to be encountered during processing of Tank $2 \mathrm{~F}$. The SL is included, in addition to the calculations for the undrained dissolved salt (UDS-0) and the prediction for the drained dissolved salt calculated with removal of $25 \%, 50 \%$, and $100 \%$ of the interstitial liquid (DDS-25, DDS-50, and DDS-100, respectively). Note that the interstitial liquid was not analyzed for this sample, and the liquid phase is assumed equivalent to the supernatant liquid. As with the Tank $3 \mathrm{~F}$ analysis, the undrained dissolved salt and the predicted drained dissolved salt streams are compared at a total sodium ion concentration of $6 \mathrm{M}$. These $6 \mathrm{M}$ may contain solids and do not indicate the solubility of the individual components in the saltcake. For Tank $2 \mathrm{~F}$, the estimated sludge composition (ignoring aluminum and silicon) is approximately $92 \mathrm{wt} \%$ $\mathrm{Fe}(\mathrm{OH})_{3}, 6$ wt $\% \mathrm{Cr}(\mathrm{OH})_{3}, 2$ wt $\% \mathrm{MnO}_{2}$, and 1 wt $\% \mathrm{BaSO}_{4}$.

Figure 14 and appendix Table 34 indicate the likely composition of the solid phase in the original undrained sample, formulated from the major components of saltcake after IL removal (similar to DDS-100). Finally, the saltcake composition is normalized to sum to $100 \mathrm{wt} \%$. The un-normalized composition summed to only $84 \mathrm{wt} \%$, which is moderately good agreement, considering the multiple sample preparations and analyses that are performed. 
WSRC-TR-2004-00131

Revision 0

Table 10: Radiological Composition of Tank 2F Samples

\begin{tabular}{|c|c|c|c|c|c|c|c|}
\hline \multirow{3}{*}{ Analyte } & \multirow{3}{*}{ Units } & \multirow{3}{*}{ Method } & \multirow{2}{*}{\multicolumn{2}{|c|}{$\frac{\mathrm{T} 2 \mathrm{~F}-1-1}{\text { undrained saltcake }}$}} & \multicolumn{2}{|c|}{ FTF-245, 246} & \multirow{3}{*}{$\begin{array}{l}\text { Partition } \\
\text { Into IL (\%) }\end{array}$} \\
\hline & & & & & \multirow{2}{*}{ SL (unfiltered) } & \multirow{2}{*}{ SL (filtered) } & \\
\hline & & & Average & StDev & & & \\
\hline${ }^{14} \mathrm{C}$ & $\mathrm{pCi} / \mathrm{g}$ & Rad. Chem. & \multicolumn{2}{|l|}{$1.8 \mathrm{E}+03$} & - & $<8.11 \mathrm{E}+02$ & $<6$ \\
\hline${ }^{90} \mathrm{Sr}$ & $\mathrm{pCi} / \mathrm{g}$ & Rad. Chem. & \multicolumn{2}{|l|}{$1.3 E+06$} & $3.39 \mathrm{E}+04$ & $4.92 E+03$ & 0.05 \\
\hline${ }^{99} \mathrm{Tc}$ & $\mathrm{pCi} / \mathrm{g}$ & ICP-MS & \multicolumn{2}{|l|}{$4.1 \mathrm{E}+04$} & $2.71 \mathrm{E}+05$ & $2.76 \mathrm{E}+05$ & 86 \\
\hline${ }^{135} \mathrm{Cs}$ & $\mathrm{pCi} / \mathrm{g}$ & ICP-MS & \multicolumn{2}{|l|}{$9.6 \mathrm{E}+02$} & $5.09 \mathrm{E}+03$ & $5.15 \mathrm{E}+03$ & 69 \\
\hline${ }^{137} \mathrm{Cs}$ & $\overline{\mathrm{pCi} / \mathrm{g}}$ & Rad. Chem. & \multicolumn{2}{|l|}{$9.70 \mathrm{E}+07$} & $1.09 E+09$ & $1.09 E+09$ & 146 \\
\hline${ }^{230} \mathrm{Th}$ & $\mathrm{pCi} / \mathrm{g}$ & ICP-MS & \multicolumn{2}{|l|}{$<1.6 \mathrm{E}+02$} & $<6.8 \mathrm{E}+02$ & $<7.0 \mathrm{E}+02$ & - \\
\hline${ }^{232} \mathrm{Th}$ & $\mathrm{pCi} / \mathrm{g}$ & ICP-MS & \multicolumn{2}{|l|}{$2.8 \mathrm{E}-02$} & $<3.5 \mathrm{E}-03$ & $<3.6 \mathrm{E}-03$ & $<2$ \\
\hline${ }^{233} \mathrm{U}$ & $\mathrm{pCi} / \mathrm{g}$ & ICP-MS & \multicolumn{2}{|l|}{$<7.3 \mathrm{E}+01$} & $<3.1 \mathrm{E}+02$ & $<3.2 \mathrm{E}+02$ & -- \\
\hline${ }^{234} \mathrm{U}$ & $\mathrm{pCi} / \mathrm{g}$ & ICP-MS & \multicolumn{2}{|l|}{$<4.7 \mathrm{E}+01$} & $<2.0 \mathrm{E}+02$ & $<2.1 \mathrm{E}+02$ & - \\
\hline${ }^{235} \mathrm{U}$ & $\mathrm{pCi} / \mathrm{g}$ & ICP-MS & \multicolumn{2}{|l|}{$2.5 \mathrm{E}-01$} & $<7.0 \mathrm{E}-02$ & $<7.2 \mathrm{E}-02$ & $<4$ \\
\hline${ }^{236} \mathrm{U}$ & $\mathrm{pCi} / \mathrm{g}$ & ICP-MS & \multicolumn{2}{|l|}{$1.8 \mathrm{E}+00$} & $<2.1 \mathrm{E}+00$ & $<2.2 \mathrm{E}+00$ & $<16$ \\
\hline${ }^{237} \mathrm{~Np}$ & $\mathrm{pCi} / \mathrm{g}$ & ICP-MS & \multicolumn{2}{|l|}{$<5.3 \mathrm{E}+00$} & $<2.3 \mathrm{E}+01$ & $<2.3 \mathrm{E}+01$ & - \\
\hline${ }^{238} \mathrm{U}$ & $\mathrm{pCi} / \mathrm{g}$ & ICP-MS & \multicolumn{2}{|l|}{$7.0 \mathrm{E}+00$} & 2.2E-01 & 2.4E-01 & 0.4 \\
\hline${ }^{238} \mathrm{Pu}$ & $\mathrm{pCi} / \mathrm{g}$ & Rad. Chem. & \multicolumn{2}{|l|}{$1.08 \mathrm{E}+04$} & $<5.59 \mathrm{E}+02$ & $<6.58 \mathrm{E}+02$ & $<1$ \\
\hline${ }^{239 / 240} \mathrm{Pu}$ & $\mathrm{pCi} / \mathrm{g}$ & Rad. Chem. & \multicolumn{2}{|c|}{$6.47 \mathrm{E}+03 \quad 1.09 \mathrm{E}+03$} & $<2.60 \mathrm{E}+02$ & $<4.60 \mathrm{E}+02$ & $<1$ \\
\hline${ }^{239} \mathrm{Pu}$ & $\mathrm{pCi} / \mathrm{g}$ & ICP-MS & $5.3 E+03$ & $5 \mathrm{E}+02$ & $<2.0 \mathrm{E}+03$ & $<2.1 \mathrm{E}+03$ & $<5$ \\
\hline${ }^{240} \mathrm{Pu}$ & $\mathrm{pCi} / \mathrm{g}$ & ICP-MS & $6.2 E+03$ & $9 \mathrm{E}+02$ & $<7.3 \mathrm{E}+03$ & $<7.6 \mathrm{E}+03$ & $<16$ \\
\hline${ }^{241} \mathrm{Pu}$ & $\mathrm{pCi} / \mathrm{g}$ & ICP-MS/RdChm & -- & - & -- & -- & - \\
\hline${ }^{241} \mathrm{Am}$ & $\mathrm{pCi} / \mathrm{g}$ & Rad. Chem. & $3.63 E+03$ & $9.4 \mathrm{E}+02$ & $<4.55 \mathrm{E}+02$ & $<6.62 \mathrm{E}+02$ & $<2$ \\
\hline${ }^{242} \mathrm{Pu}$ & $\mathrm{pCi} / \mathrm{g}$ & ICP-MS & $<2.9 \mathrm{E}+01$ & - & $<1.2 \mathrm{E}+02$ & $<1.3 \mathrm{E}+02$ & $<57$ \\
\hline \multicolumn{8}{|c|}{ Uranium Summary } \\
\hline Total U & wt $\%$ & ICP-MS & $2.1 \mathrm{E}-03$ & 4.0E-04 & 6.63E-05 & 7.00E-05 & 0.4 \\
\hline${ }^{235} \mathrm{U}$ Enrichment & wt $\%$ & ICP-MS & $0.56 \%$ & $0.01 \%$ & $<5 \%$ & $<5 \%$ & -- \\
\hline
\end{tabular}


Table 11: lonic Composition of Tank 2F Samples

\begin{tabular}{|c|c|c|c|c|c|c|c|}
\hline \multirow{3}{*}{ Analyte } & \multirow{3}{*}{ Units } & \multirow{3}{*}{ Method } & \multirow{2}{*}{\multicolumn{2}{|c|}{$\frac{\mathrm{T} 2 \mathrm{~F}-1-1}{\text { undrained saltcake }}$}} & \multicolumn{2}{|c|}{ FTF-245, 246} & \multirow{3}{*}{$\begin{array}{l}\text { Partition } \\
\text { Into IL (\%) }\end{array}$} \\
\hline & & & & & \multirow{2}{*}{ SL (unfiltered) } & \multirow{2}{*}{ SL (filtered) } & \\
\hline & & & Average & StDev & & & \\
\hline $\mathrm{Na}^{+}$ & wt $\%$ & ICP-ES & $2.53 E+01$ & 2E-01 & $1.86 \mathrm{E}+01$ & $1.84 \mathrm{E}+01$ & 9 \\
\hline $\mathrm{NO}_{3}{ }^{-}$ & wt \% & IC & 4.76E+01 & $2.0 \mathrm{E}+00$ & -- & $7.09 E+00$ & 2 \\
\hline $\mathrm{NO}_{2}^{-}$ & wt $\%$ & IC & $1.26 \mathrm{E}+00$ & $5 E-02$ & -- & $7.63 E+00$ & 79 \\
\hline $\mathrm{OH}^{-}$ & wt $\%$ & Wet Chem. & $2.37 \mathrm{E}+00$ & 8.7E-01 & -- & $7.77 \mathrm{E}+00$ & 42 \\
\hline $\mathrm{OH}^{-}$ & wt \% & Calcutated & $1.99 \mathrm{E}+00$ & $1.1 \mathrm{E}+00$ & -- & $1.11 \mathrm{E}+01$ & 72 \\
\hline $\mathrm{AlO}_{2}^{-}$ & wt \% & ICP-ES & $3.12 \mathrm{E}+00$ & 4E-01 & $3.56 \mathrm{E}+00$ & $3.40 \mathrm{E}+00$ & 14 \\
\hline $\mathrm{CO}_{3}{ }^{2-}$ & wt \% & TIC/TOC & $1.40 \mathrm{E}+00$ & $6.5 \mathrm{E}-01$ & -- & 7.90E-01 & 7 \\
\hline $\mathrm{SO}_{4}{ }^{2-}$ & wt $\%$ & IC & 4.31E-01 & $2.2 \mathrm{E}-02$ & -- & $3.40 \mathrm{E}-02$ & 1 \\
\hline $\mathrm{SO}_{4}{ }^{2-}$ & wt \% & ICP-ES & 5.56E-01 & 1.3E-01 & 8.21E-02 & $</=7.25 \mathrm{E}-02$ & 2 \\
\hline $\mathrm{PO}_{4}{ }^{3-}$ & wt \% & IC & 4.01E-02 & 8.7E-03 & -- & 3.35E-01 & 108 \\
\hline $\mathrm{PO}_{4}{ }^{3-}$ & wt \% & ICP-ES & $</=8.3 E-02$ & 1.6E-02 & 3.63E-01 & 3.06E-01 & 48 \\
\hline $\mathrm{Cl}^{-}$ & wt \% & IC & $</=1.67 \mathrm{E}-02$ & 7.6E-03 & -- & 3.64E-02 & 28 \\
\hline $\mathrm{F}^{-}$ & wt \% & IC & $<1.00 \mathrm{E}-02$ & -- & -- & $<9.72 \mathrm{E}-03$ & -- \\
\hline $\mathrm{C}_{2} \mathrm{O}_{4}{ }^{2-}$ & wt \% & IC & $6.85 E-02$ & 2.7E-03 & -- & $3.89 \mathrm{E}-03$ & 1 \\
\hline $\mathrm{CHO}_{2}{ }^{-}$ & wt \% & IC & $<5.01 \mathrm{E}-02$ & -- & -- & $<4.86 \mathrm{E}-02$ & -- \\
\hline $\mathrm{K}^{+}$ & wt $\%$ & AA & $4.9 \mathrm{E}-02$ & $1 \mathrm{E}-03$ & $6.1 \mathrm{E}-01$ & $6.1 \mathrm{E}-01$ & 163 \\
\hline $\mathrm{K}^{+}$ & wt \% & ICP-ES & $<4.72 \mathrm{E}-01$ & - & 6.51E-01 & 7.13E-01 & $>20$ \\
\hline $\mathrm{Cs}^{+}$ & wt $\%$ & ICP-MS/RdChm & 4.20E-04 & 9E-06 & $4.51 \mathrm{E}-03$ & 4.55E-03 & 140 \\
\hline TOC & wt \% & TIC/TOC & $1.05 \mathrm{E}+00$ & 8.6E-01 & -- & 2.02E-01 & 2 \\
\hline Mass Balance & $\%$ & Calcutated & 89 & & -- & 95 & -- \\
\hline Charge Bal $(-/+)$ & $\%$ & Calcutated & 95 & & -- & 102 & -- \\
\hline
\end{tabular}


WSRC-TR-2004-00131

Revision 0

Table 12: Other Elemental Composition of Tank 2F Samples

\begin{tabular}{|c|c|c|c|c|c|c|c|}
\hline \multirow{3}{*}{ Analyte } & \multirow{3}{*}{ Units } & \multirow{3}{*}{ Method } & \multirow{2}{*}{\multicolumn{2}{|c|}{$\begin{array}{c}\text { T2F-1-1 } \\
\text { undrained saltcake }\end{array}$}} & \multicolumn{2}{|c|}{ FTF-245, 246} & \multirow{3}{*}{$\begin{array}{l}\text { Partition } \\
\text { Into IL (\%) }\end{array}$} \\
\hline & & & & & \multirow{2}{*}{ SL (unfiltered) } & \multirow{2}{*}{ SL (filtered) } & \\
\hline & & & Average & StDev & & & \\
\hline $\mathrm{Ag}$ & wt $\%$ & ICP-ES & $<7.44 \mathrm{E}-04$ & -- & $<7.06 \mathrm{E}-04$ & $<7.28 \mathrm{E}-04$ & -- \\
\hline As & wt $\%$ & AA & $<2.5 \mathrm{E}-04$ & -- & $<2.4 \mathrm{E}-04$ & $<2.4 \mathrm{E}-04$ & -- \\
\hline$B$ & wt $\%$ & ICP-ES & $<8.03 \mathrm{E}-02$ & -- & $<7.62 \mathrm{E}-02$ & $<7.86 \mathrm{E}-02$ & -- \\
\hline $\mathrm{Ba}$ & wt \% & ICP-ES & $2.64 \mathrm{E}-03$ & 3.2E-04 & $<7.06$ E-04 & $<7.28 \mathrm{E}-04$ & $<4$ \\
\hline $\mathrm{Ca}$ & wt $\%$ & ICP-ES & $<2.25 \mathrm{E}-02$ & -- & $<2.13 \mathrm{E}-02$ & $<2.20$ E-02 & -- \\
\hline $\mathrm{Cd}$ & wt \% & ICP-ES & $<9.92 \mathrm{E}-04$ & -- & $<9.41 \mathrm{E}-04$ & $<9.71 \mathrm{E}-04$ & -- \\
\hline $\mathrm{Ce}$ & wt $\%$ & ICP-ES & $<1.23 E-02$ & -- & $<1.17 \mathrm{E}-02$ & $<1.20 \mathrm{E}-02$ & -- \\
\hline Co & wt \% & ICP-MS & $6.0 \mathrm{E}-05$ & $2.5 \mathrm{E}-05$ & $1.4 \mathrm{E}-05$ & 1.3E-05 & 3 \\
\hline $\mathrm{Cr}$ & wt $\%$ & ICP-ES & 9.93E-03 & 9.7E-04 & $1.88 \mathrm{E}-02$ & 1.77E-02 & 23 \\
\hline $\mathrm{Cu}$ & wt $\%$ & ICP-ES & $<1.54 \mathrm{E}-03$ & -- & $<1.46 \mathrm{E}-03$ & $<1.50 \mathrm{E}-03$ & -- \\
\hline $\mathrm{Fe}$ & wt \% & ICP-ES & $1.52 \mathrm{E}-01$ & $2.0 \mathrm{E}-02$ & $1.80 \mathrm{E}-03$ & $<1.07 \mathrm{E}-03$ & 0.09 \\
\hline $\mathrm{Gd}$ & wt \% & ICP-ES & $<1.34 \mathrm{E}-03$ & - & $<1.27 \mathrm{E}-03$ & $<1.31 \mathrm{E}-03$ & - \\
\hline $\mathrm{Hg}$ & wt $\%$ & CV AA & $<1.8 \mathrm{E}-02$ & - & $<5.2 \mathrm{E}-04$ & $<5.3 \mathrm{E}-04$ & -- \\
\hline $\mathrm{La}$ & wt $\%$ & ICP-ES & $<9.92 \mathrm{E}-04$ & -- & $<9.41 \mathrm{E}-04$ & $<9.71 \mathrm{E}-04$ & - \\
\hline $\mathrm{Li}$ & wt \% & ICP-ES & $<4.21 \mathrm{E}-03$ & - & $<4.00 \mathrm{E}-03$ & $<4.13 \mathrm{E}-03$ & - \\
\hline $\mathrm{Mg}$ & wt $\%$ & ICP-ES & $</=3.6 \mathrm{E}-03$ & 9E-04 & $<2.92 \mathrm{E}-03$ & $<3.01 \mathrm{E}-03$ & $<11$ \\
\hline $\mathrm{Mn}$ & wt $\%$ & ICP-ES & $3.15 \mathrm{E}-03$ & 1.21E-03 & $<1.04 \mathrm{E}-03$ & $<1.07 \mathrm{E}-03$ & $<4$ \\
\hline Mo & wt $\%$ & ICP-ES & $<1.01 \mathrm{E}-02$ & -- & $1.27 \mathrm{E}-02$ & $</=1.16 \mathrm{E}-02$ & $>15$ \\
\hline $\mathrm{Ni}$ & wt \% & ICP-ES & $<3.72$ E-03 & - & $<3.53 E-03$ & $<3.64 \mathrm{E}-03$ & -- \\
\hline $\mathrm{Pb}$ & wt $\%$ & ICP-ES & $<1.22 \mathrm{E}-02$ & - & $<1.16 \mathrm{E}-02$ & $<1.19 \mathrm{E}-02$ & - \\
\hline $\mathrm{Sb}$ & wt $\%$ & ICP-ES & $<7.49 \mathrm{E}-03$ & - & $<7.11 \mathrm{E}-03$ & $<7.33 \mathrm{E}-03$ & - \\
\hline $\mathrm{Si}$ & wt $\%$ & ICP-ES & $7.1 \mathrm{E}-03$ & 4.2E-03 & $2.05 \mathrm{E}-02$ & 4.57E-02 & 84 \\
\hline $\mathrm{Se}$ & wt $\%$ & AA & $<2.5 \mathrm{E}-04$ & -- & $<2.4 \mathrm{E}-04$ & $<2.4 \mathrm{E}-04$ & - \\
\hline $\mathrm{Sn}$ & wt $\%$ & ICP-ES & $<1.21 \mathrm{E}-02$ & -- & $<1.15 \mathrm{E}-02$ & $<1.19 \mathrm{E}-02$ & - \\
\hline $\mathrm{Sr}$ & wt $\%$ & ICP-ES & $<4.96 \mathrm{E}-03$ & -- & $<4.71 \mathrm{E}-03$ & $<4.85 \mathrm{E}-03$ & -- \\
\hline $\mathrm{Ti}$ & wt \% & ICP-ES & $<2.97 \mathrm{E}-04$ & -- & $<2.82 \mathrm{E}-04$ & $<2.91 \mathrm{E}-04$ & -- \\
\hline $\mathrm{V}$ & wt $\%$ & ICP-ES & -- & -- & $</=5.33 E-04$ & $<5.34 \mathrm{E}-04$ & -- \\
\hline $\mathrm{Zn}$ & wt $\%$ & ICP-ES & $<2.73 \mathrm{E}-03$ & -- & $<2.59 \mathrm{E}-03$ & $<2.67 \mathrm{E}-03$ & -- \\
\hline $\mathrm{Zr}$ & wt $\%$ & ICP-ES & $<5.95 \mathrm{E}-04$ & -- & $<5.65 \mathrm{E}-04$ & $<5.83 E-04$ & -- \\
\hline
\end{tabular}


Table 13: Potential Streams During Draining and Dissolution of Tank 2F Saltcake

\begin{tabular}{|c|c|c|c|c|c|c|c|}
\hline Analyte & Units & Method & SL & UDS-0 & DDS-25* & DDS-50* & DDS-100* \\
\hline $\mathrm{Na}^{+}$ & $M$ & ICP-ES & 12.04 & 6.00 & 6.00 & 6.00 & 6.00 \\
\hline $\mathrm{NO}_{3}{ }^{-}$ & $\mathrm{M}$ & IC & 1.72 & 4.19 & 4.27 & 4.35 & 4.53 \\
\hline $\mathrm{NO}_{2}{ }^{-}$ & $M$ & IC & 2.49 & 0.149 & 0.123 & 0.095 & 0.035 \\
\hline $\mathrm{OH}^{-}$ & M & Wet Chem. & 6.87 & 0.76 & 0.70 & 0.63 & 0.48 \\
\hline $\mathrm{OH}^{-}$ & M & Calcutated & 9.85 & 0.64 & 0.54 & 0.43 & 0.19 \\
\hline $\mathrm{AlO}_{2}$ & M & ICP-ES & 0.87 & 0.29 & 0.28 & 0.28 & 0.27 \\
\hline $\mathrm{CO}_{3}{ }^{2-}$ & $M$ & TIC/TOC & 0.20 & 0.13 & 0.13 & 0.13 & 0.13 \\
\hline $\mathrm{SO}_{4}{ }^{2-}$ & $M$ & IC & 0.0053 & 0.024 & 0.025 & 0.026 & 0.027 \\
\hline $\mathrm{SO}_{4}{ }^{2-}$ & $M$ & ICP-ES & 0.0114 & 0.032 & 0.032 & 0.033 & 0.034 \\
\hline $\mathrm{PO}_{4}{ }^{3-}$ & $M$ & IC & 0.053 & 0.0023 & 0.0017 & 0.0011 & 0 \\
\hline $\mathrm{PO}_{4}{ }^{3-}$ & $M$ & ICP-ES & 0.049 & 0.0048 & 0.0043 & 0.0038 & 0.0027 \\
\hline $\mathrm{Cl}^{-}$ & M & IC & 0.015 & 0.0026 & 0.0024 & 0.0023 & 0.0020 \\
\hline $\mathrm{F}^{-}$ & M & IC & $<0.0077$ & $<0.0029$ & -- & -- & -- \\
\hline $\mathrm{C}_{2} \mathrm{O}_{4}{ }^{2-}$ & $M$ & IC & 0.0007 & 0.0042 & 0.0043 & 0.0044 & 0.0047 \\
\hline $\mathrm{CHO}_{2}{ }^{-}$ & $\mathrm{M}$ & IC & $<0.016$ & $<0.0061$ & -- & -- & -- \\
\hline $\mathrm{K}^{+}$ & $M$ & AA & 0.24 & 0.0068 & 0.0041 & 0.0013 & 0 \\
\hline $\mathrm{K}^{+}$ & $\mathrm{M}$ & $\mathrm{AA}$ & 0.27 & -- & - & -- & -- \\
\hline $\mathrm{Cs}^{+}$ & $\mathrm{mM}$ & ICP-MS/RdChm & 0.0507 & 0.0170 & 0.0113 & 0.0053 & 0 \\
\hline${ }^{137} \mathrm{Cs}$ & $\mathrm{pCi} / \mathrm{mL}$ & Rad. Chem. & $1.64 \mathrm{E}+09$ & $5.29 E+07$ & $3.44 \mathrm{E}+07$ & $1.51 \mathrm{E}+07$ & 0 \\
\hline${ }^{238} \mathrm{Pu}$ & $\mathrm{pCi} / \mathrm{mL}$ & Rad. Chem. & $9.89 E+02$ & $5.91 E+03$ & $6.04 E+03$ & $6.18 \mathrm{E}+03$ & $6.47 \mathrm{E}+03$ \\
\hline sludge & $\mathrm{mg} / \mathrm{L}$ & ICP-ES & -- & 1745 & 1779 & 1816 & 1895 \\
\hline \multicolumn{3}{|c|}{ g salt / L 6M Na } & -- & 545 & 540 & 535 & 524 \\
\hline
\end{tabular}

* Drained Dissolved Salt solutions calculated by removing a percentage (25\%, 50\%, or $100 \%)$ of the IL/SL. 


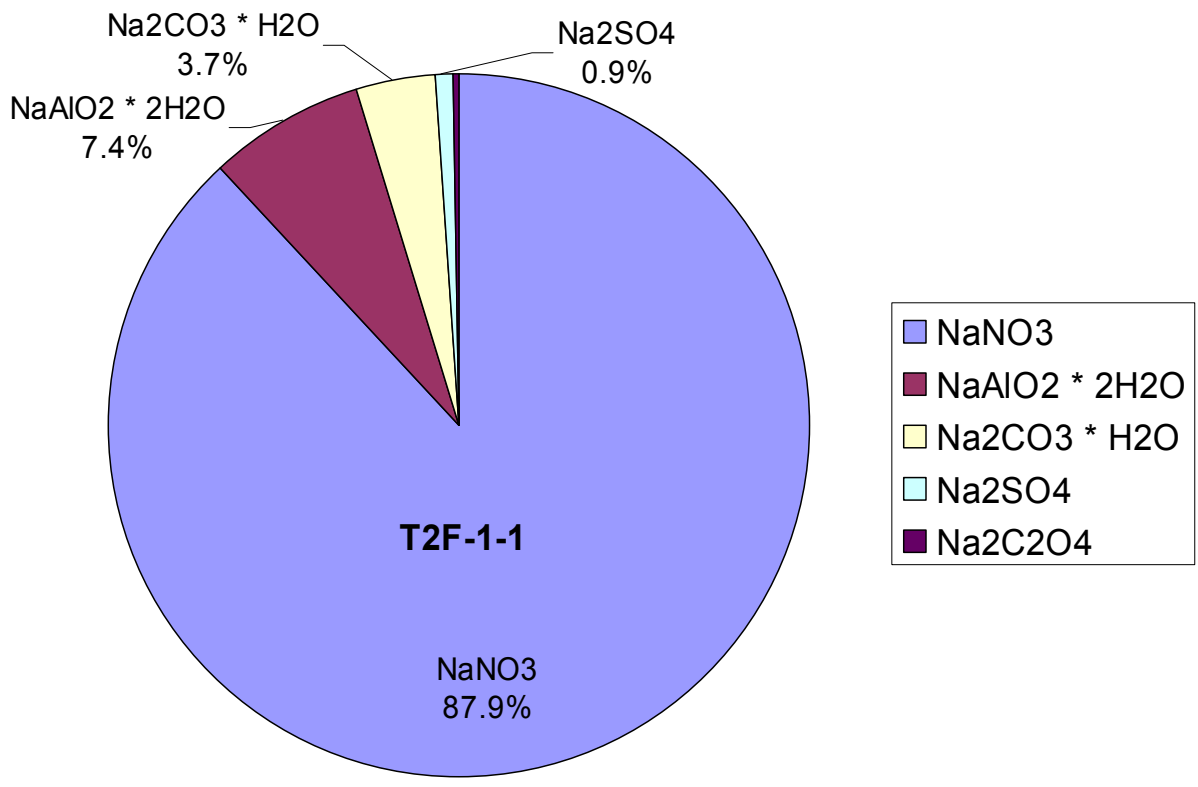

Figure 14: Likely major components of Tank $2 \mathrm{~F}$ salt solids, normalized to $100 \mathrm{wt} . \%$

\section{Microscopy of Bulk Saltcake}

\section{Tank 3F}

The Tank 3F salt samples for scanning electron microscopy consisted of two samples collected from the bottoms of tubes T3F-1-1 (FTF-223) and T3F-1-3 (FTF-224) of the 36 inch saltcake core. The differences in these two samples are described below and show the heterogeneity found within the collected saltcake core.

\section{T3F-1-1 (FTF-223) Sample:}

Examination using SEM suggests that T3F-1-1 consists of large (1 by $2 \mathrm{~mm}$ in size), blocky (possibly rhombic) grains. These grains are larger than those seen in Tank $2 \mathrm{~F}$ samples, which ranged from approximately 0.050 to $0.2 \mathrm{~mm}$. As shown in Figure 15, smaller crystals appear to drape over the larger grain in this sample. Microporosity is evident within the grains. Pore sizes range from 25 to 100 microns in diameter. The microporosity within the large grain is likely not well interconnected. It is difficult to ascertain the original porosity due to coatings of the large grains by the smaller precipitates.

Closer examination of the smaller crystals reveals that some have an interconnecting, thin, platy morphology whereas other crystals appear as small, more massive or bulbous forms on top of the platy crystals and base grain (Figure 16). The exact timing of the precipitation of these secondary crystals (i.e. whether they precipitated in the tank or after sampling) is unclear. However, growth of the thin, platy crystals toward the inside of a pore space (Figure 15) implies that these crystals are from a later generation of fluid than that which formed the base crystals. In addition, their delicate nature (sharp edges and points) suggests that they may have precipitated after the collection of the sample when there would have been minimal disturbance. The initial outward appearance of the salt from the bottom of tube T3F-1-1 was characterized as "easily scooped" with a "moist consistency", suggesting that there was pore space filled with interstitial liquid. Dissolved salts within this fluid may have later precipitated as secondary crystals. The presence of the small, bulbous precipitates on top of the thin, platy crystals implies that some (or possibly all) of the bulbous precipitates are from a later generation of fluid. Elemental analysis shows that these two types of secondary precipitates (platy 
versus bulbous) have slightly different elemental compositions supporting the supposition that they may have come from a different generation of fluid.

Elemental spectra indicate that the platy crystals are dominated by sodium with minor amounts of aluminum and potassium (Figure 17). The small, bulbous precipitates and underlying base crystals appear to contain sodium, sulfur and minor amounts of potassium. These findings are consistent with the results from $\mathrm{X}$-ray diffraction, which showed that the mineralogical composition consisted of sodium nitrate $\left(\mathrm{NaNO}_{3}\right)$ with minor amounts of a sodium carbonate $\left(\mathrm{Na}_{2} \mathrm{CO}_{3}{ }^{*} \mathrm{H}_{2} \mathrm{O}\right)$ and sodium nitrite $\left(\mathrm{NaNO}_{2}\right)$ (Figure 18). The large amount of sulfur in the SEM was not identified in the XRD analysis, and remains unattributed to a crystalline phase. Since the amount of sulfur in the bulk saltcake sample is small, it is assumed that the sulfur in the SEM is due to heterogeneity. It is unclear how similar the salt samples from the tanks are to minerals found in nature, so the XRD diffraction pattern for samples can vary slightly from the pattern in the instruments library. Naturally formed sodium nitrate, nitratine, can precipitate as a massive form in which individual crystals are indistinguishable or as a granular form in which crystals may be anhedral to subhedral (crystal faces may be identified).

Elemental analysis also identified uranium, chromium, and iron in a small area on top of a small, bulbous precipitate (Spot "A", Figure 17). Presumably, this is a spec of sludge in the sample.

T3F-1-3 (FTF-224) Sample:

This sample appears to be more massive with less pore space than the previous sample (Figure 19). This observation is consistent with the initial outward appearance of the sample, which was described as very hard and extending approximately 0.25 inches beyond the end of the tube. Distinct grains are difficult to identify, however some sharp edges and flat crystal faces are evident within the matrix.

Elemental composition appears to vary slightly in the large grains, but in general consists of sodium, potassium and varying amounts of aluminum (Figure 20 and Figure 21). Small, secondary precipitates can be found on the flat surfaces of the larger grains and also appear to be composed of sodium, aluminum, and potassium. These compositions are similar to those found in the previous sample. X-ray diffraction of this sample shows that sodium nitrate $\left(\mathrm{NaNO}_{3}\right)$ and minor amounts of sodium nitrite $\left(\mathrm{NaNO}_{2}\right)$ compose the mineralogy; it lacks the sodium carbonate seen in the previous sample (Figure 22). 
WSRC-TR-2004-00131

Revision 0

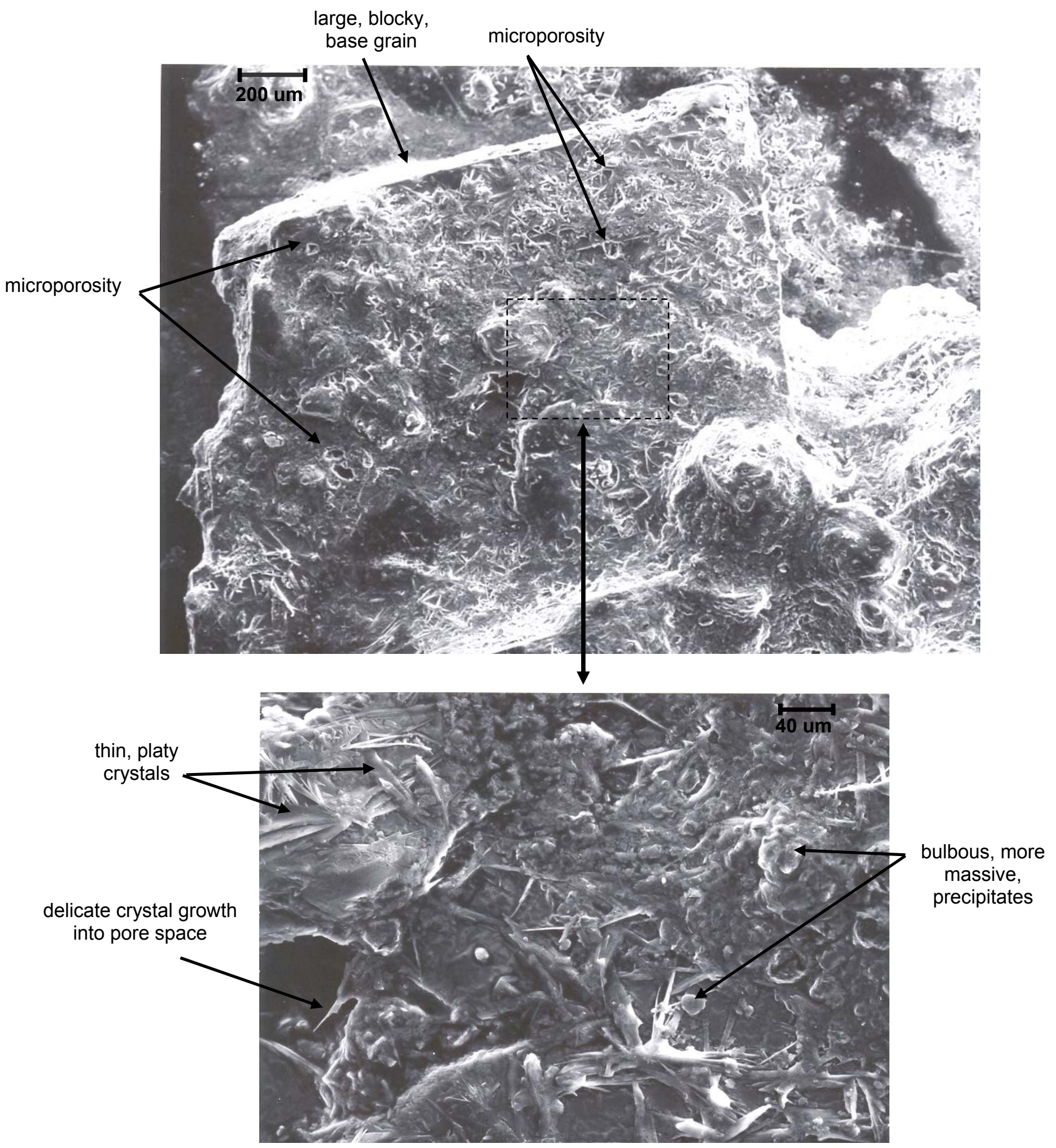

Figure 15: Sample T3F-1-1: Small precipitates covering large base grain (secondary electron image, 50X) Smaller crystals covering large grain (secondary electron image, 250X) 

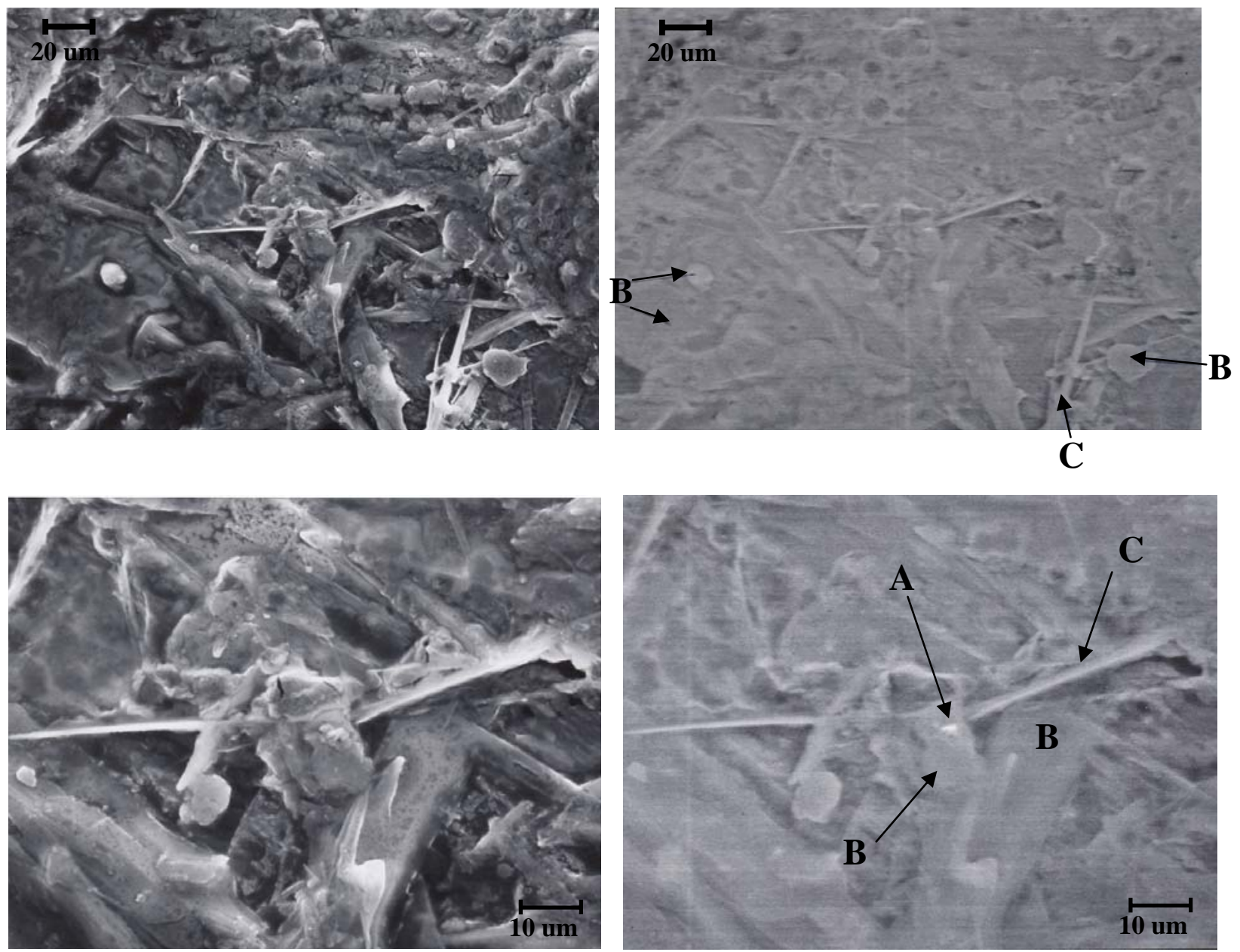

Figure 16: Secondary electron images on left and backscattered images on right (500X and 1000X); analyses from center of Figure 15. Elemental spectra for spots $A-C$ are contained in Figure 17. 


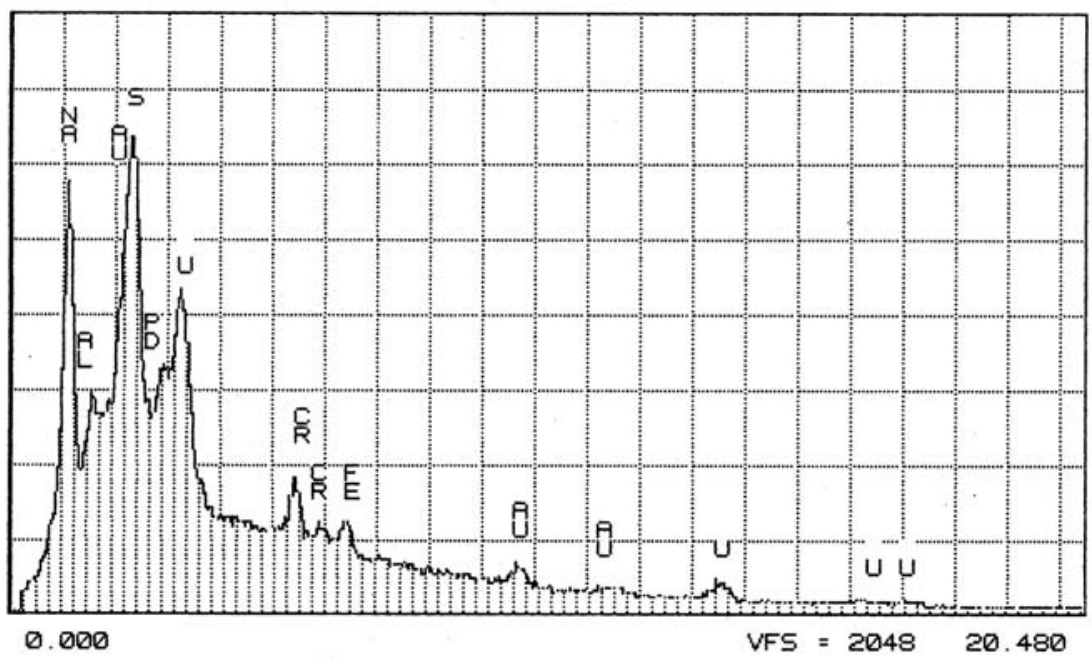

30

199576 T3F-1-1 MRRTINO PHOTO\#44 SPOT-A
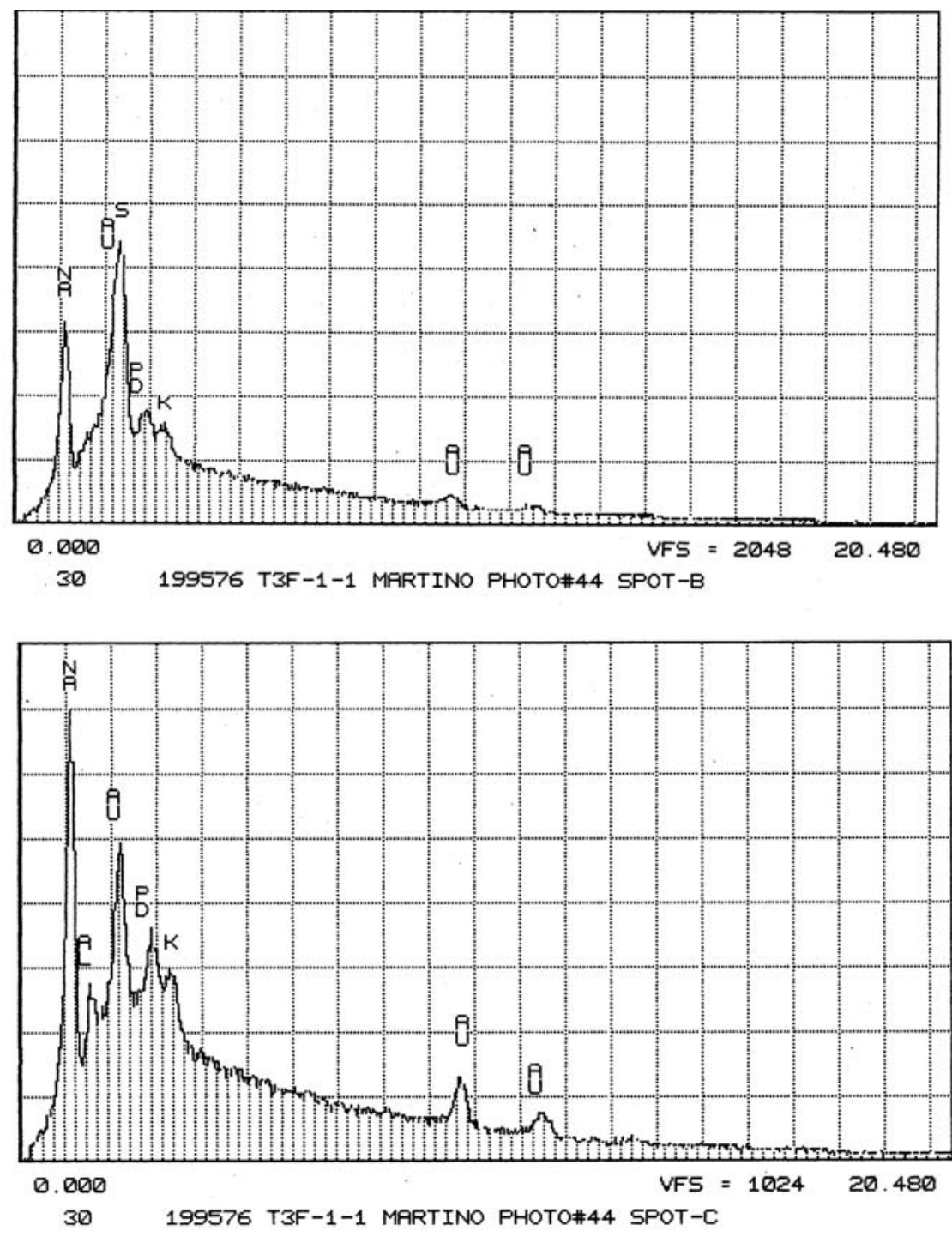

Spot "A" appears as a small, light-colored area on the backscattered image. The elemental spectrum shows that it contains sodium, aluminum, sulfur, uranium, chromium and iron. Gold and palladium peaks can be attributed to gold coating on sample.

Spot "B" represents the small bulbous precipitates and the underlying crystals. The elemental spectrum shows that these crystals consist of sodium, sulfur and minor amounts of potassium. Gold and palladium peaks can be attributed to gold coating on sample.

Spot "C" corresponds to the thin, platy crystals. The elemental spectrum shows that these crystals are dominated by sodium with minor amounts of sulfur and potassium. Gold and palladium peaks can be attributed to gold coating on sample.

Figure 17: Elemental spectra corresponding to locations identified in Figure 16 
WSRC-TR-2004-00131

Revision 0

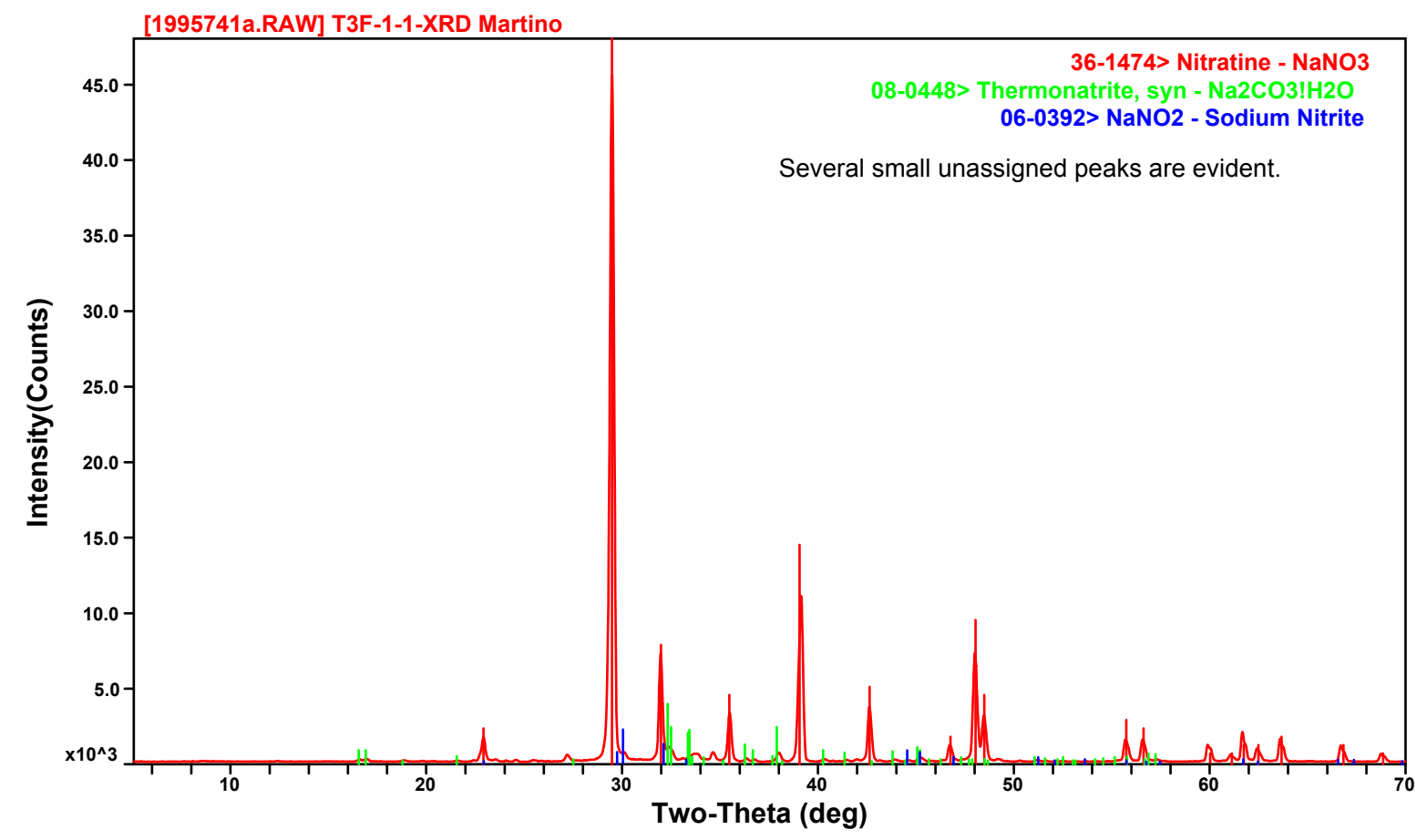

Figure 18: Results of x-ray diffraction analysis for Sample T3F-1-1 
WSRC-TR-2004-00131

Revision 0

Flat crystal faces

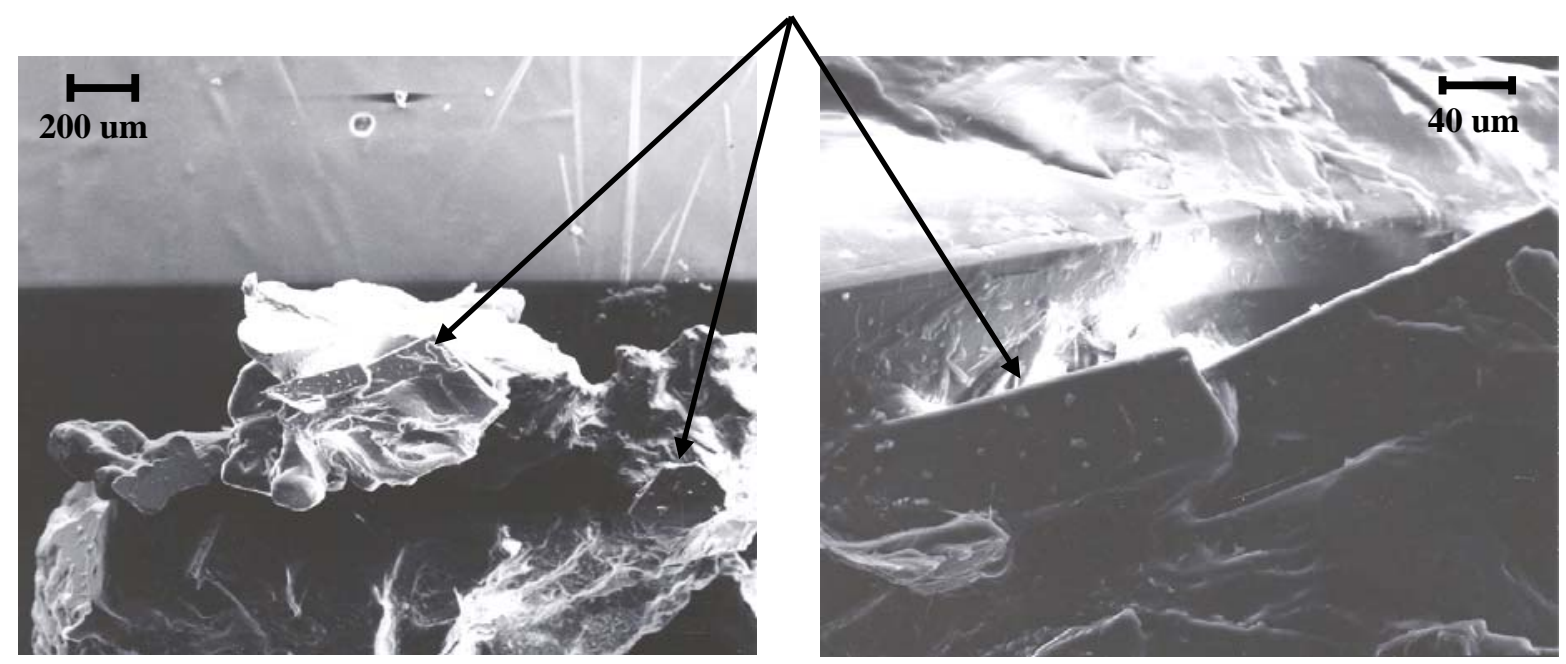

Figure 19: Sample T3F-1-3: more massive and less pore space than previous sample (secondary electron images; $50 \mathrm{X}$ on left and 250X on right)

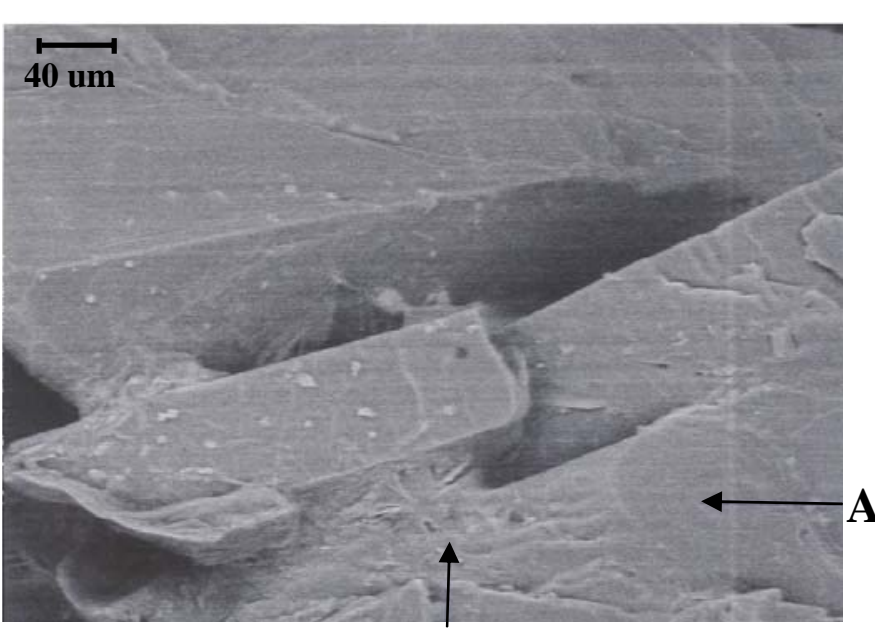

A

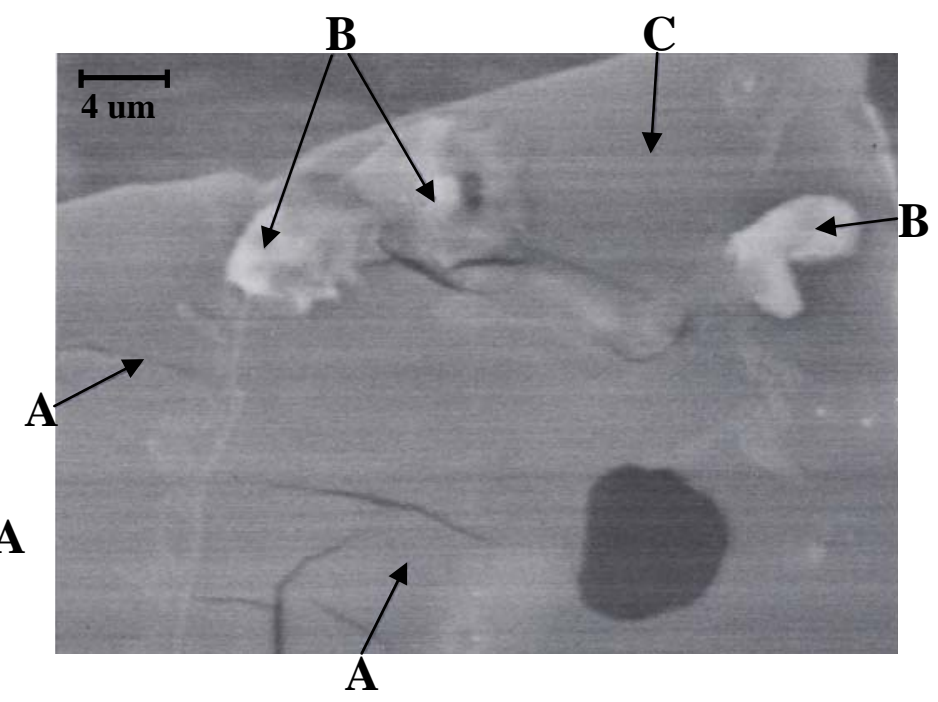

Figure 20: Backscattered images (500X and 1000X); analyses from center of Figure 19 

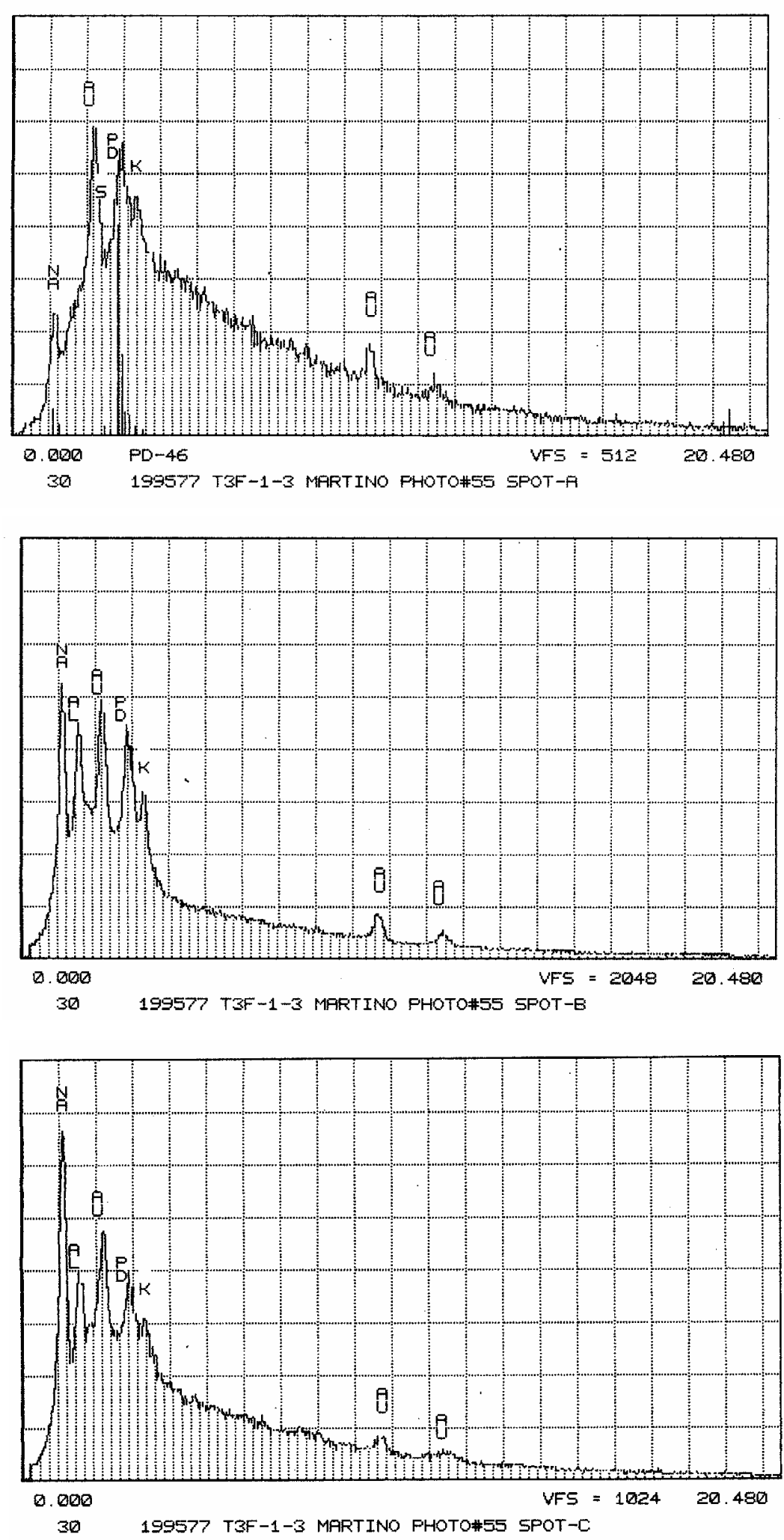

Figure 21: Elemental spectra corresponding to locations identified in Figure 20
The flat crystal faces (Spot "A") consists of sodium, sulfur and potassium. Gold and palladium peaks can be attributed to gold coating on sample.

Spot "B", the smaller precipitates on top of the flat crystal faces, contain aluminum in addition to sodium and potassium. Gold and palladium peaks can be attributed to gold coating on sample.

Spot "C", located on the flat crystal face, consists of sodium, aluminum and potassium. Gold and palladium peaks can be attributed to gold coating on sample. 


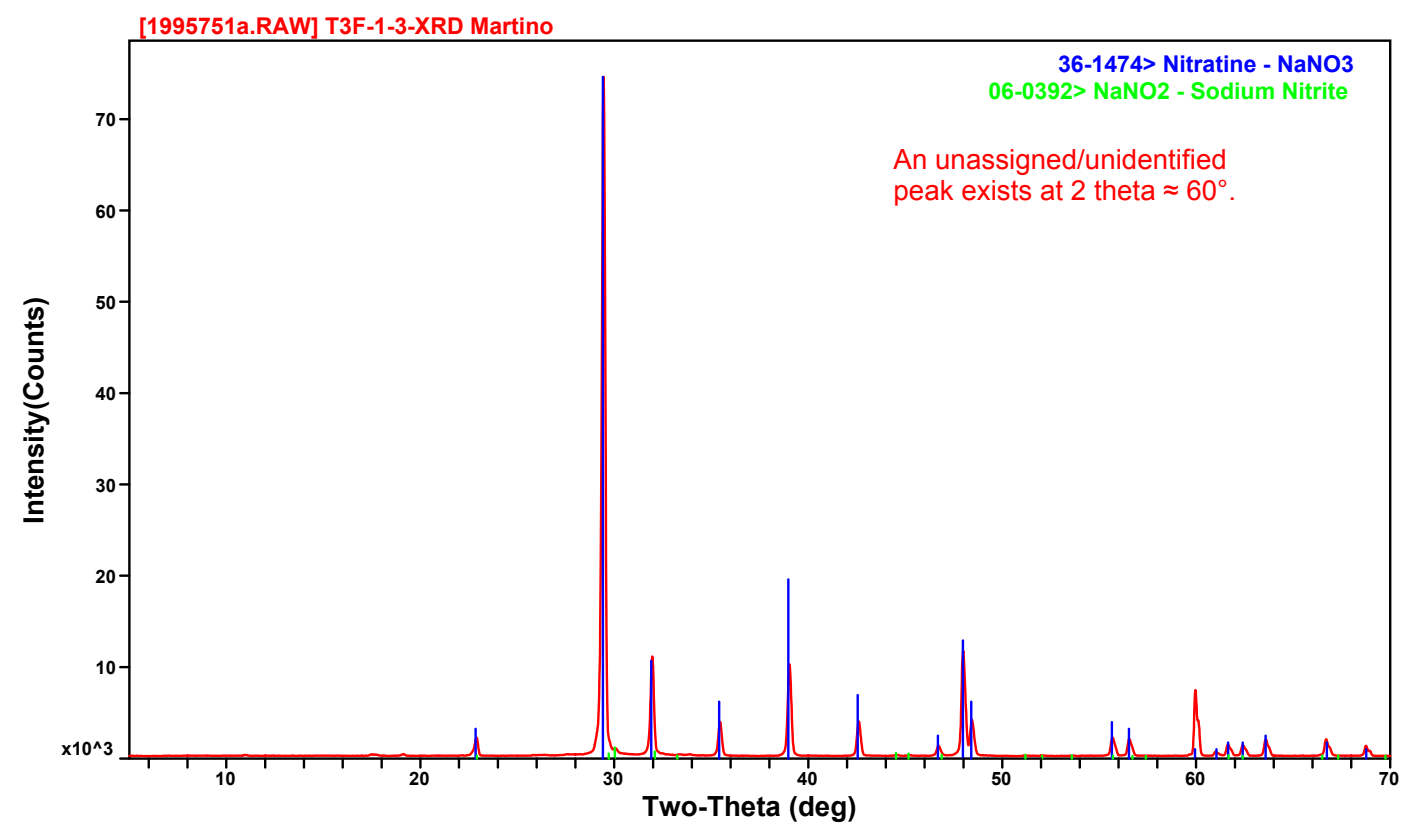

Figure 22: Results of $x$-ray diffraction analysis for Sample T3F-1-3

\section{Tank $2 F$}

Figure 23 through Figure 27 contain SEM images and EDS spectra from the investigation of Tank 2F saltcake. The salt used for microscopy was taken from the same location as the salt for chemical characterization. Note that the sample drying and coating preparation for SEM analysis causes the residual interstitial liquid to dry, leaving behind additional salts that were not part of the initial solid salt matrix. The following are the key observations made from analysis of the SEM and EDS results.

Low magnification (50X) shows the Tank $2 \mathrm{~F}$ sample to be aggregates of blocky crystals, which appear to have possibly a rhombic crystal habit and range from approximately 50 to 200 microns in size. Many of the straight edges and faces of these crystals appear to be masked or coated by finergrained precipitates. In Figure 23, some of the straight edges and faces of these blocky crystals are outlined in blue. At higher magnification (as in Figure 24), the heterogeneity of grain sizes in the Tank $2 \mathrm{~F}$ salt is more obvious.

Elemental examination of the blocky (rhombic) crystals by the SEM shows that these grains consist predominantly of $\mathrm{Na}$ with minor amounts of $\mathrm{Al}$ and $\mathrm{K}$. These results are consistent with the X-ray diffraction results, which indicate that sodium nitrate $\left(\mathrm{NaNO}_{3}\right)$ and sodium carbonate $\left(\mathrm{Na}_{2} \mathrm{CO}_{3}{ }^{*} \mathrm{H}_{2} \mathrm{O}\right)$ are the major minerals in this sample (Figure 28). The large grain labeled "C" in Figure 23 is shown at a higher magnification (100X) in Figure 24 along with an elemental spectrum. The prominent $\mathrm{Na}$ peak and sub-rhombic crystal habit suggest that this crystal is likely sodium nitrate or sodium carbonate.

Figure 25 provides analyses of a large grain from another location in the sample at higher magnification (2000X). The large base grain, labeled "B", shows evidence of higher Na than Al also suggesting that it is possibly a sodium nitrate or sodium carbonate crystal. In contrast, the finer grained precipitates, which appear as needle-like crystals and as thin coatings, have greater concentrations of $\mathrm{Al}$ than $\mathrm{Na}$. These subtle differences in composition may reflect different generations of precipitates and fluid compositions. One explanation may be that as the larger, $\mathrm{Na}$ rich crystals precipitated, the fluid composition became enriched in Al. This enrichment led to a later 
generation of precipitates (fine grained) with higher Al concentrations. The different generation(s) of precipitates may have some significance in the dissolution of the salt.

At higher magnification, the porosity of the sample (in addition to heterogeneity in grain size) is more evident. The pore spaces appear to range in size from $<2 \mu \mathrm{m}$ to approximately $40 \mu \mathrm{m}$ and vary in shape with oval to angular openings (Figure 26 and Figure 27). It is unclear from these SEM photographs the interconnectivity of these pores, but it is likely that the heterogeneities in their size and shape will affect fluid flow. It is also interesting to note that traces of quartz were identified in the sample, the origin of which is unknown.

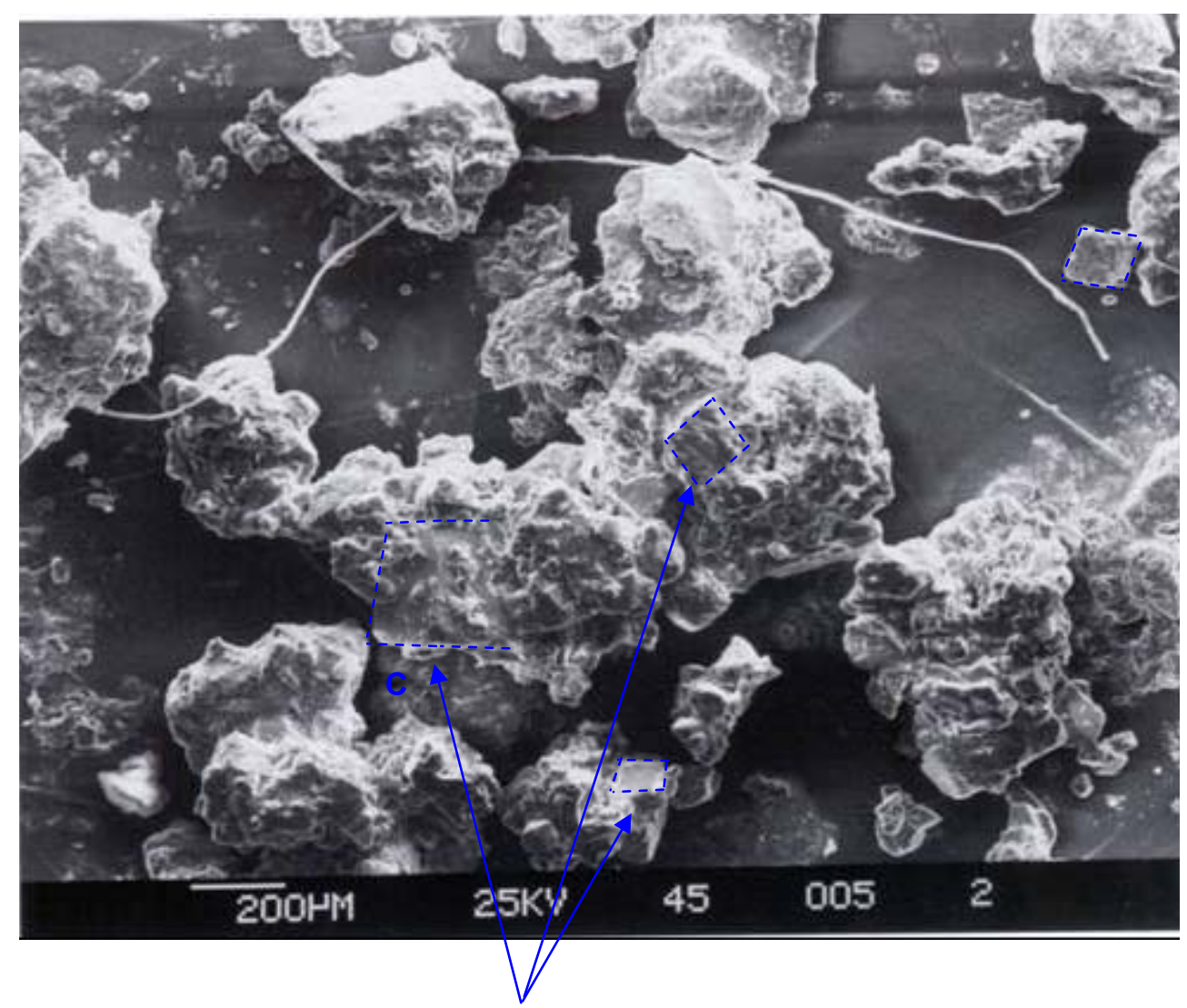

Examples of blocky, (possibly rhombic) crystal faces

Figure 23: Low magnification (50X) Tank 2F Salt 
WSRC-TR-2004-00131

Revision 0

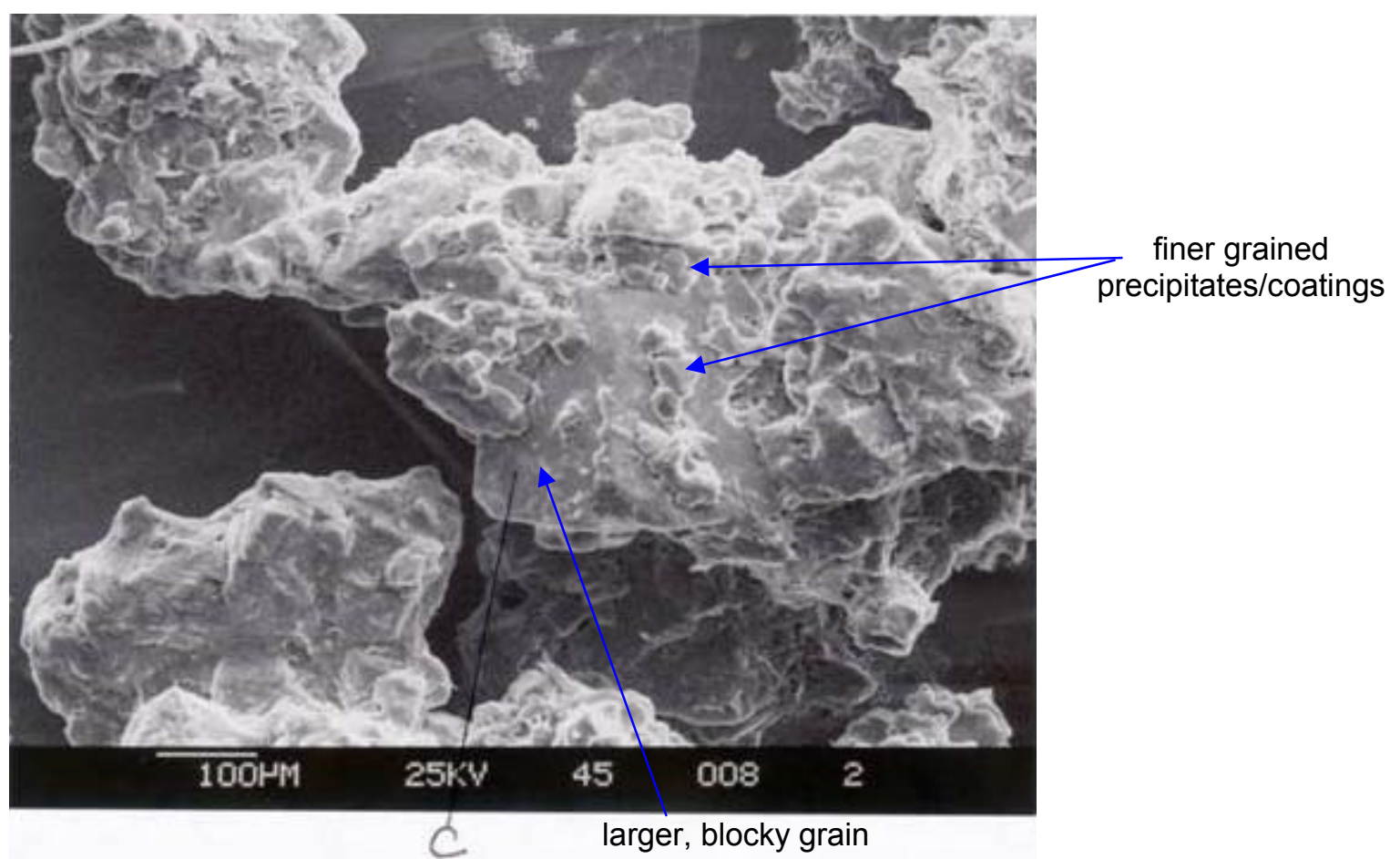

TN-5502 WSRC CSEM.

Cursor: $0.000 \mathrm{keV}=0$

TUE 18-NOV-03 14:46

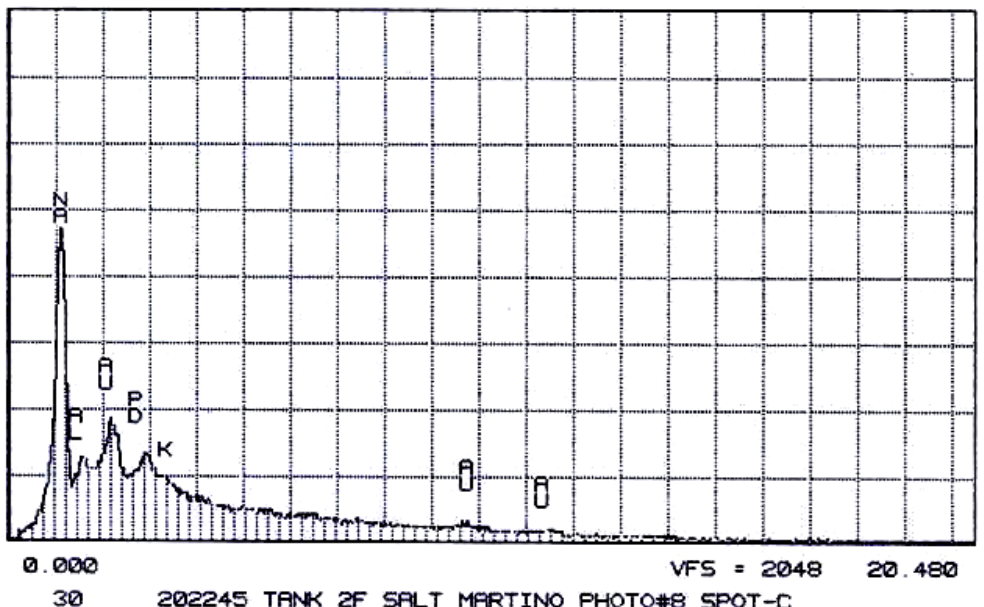

Figure 24: Examination of blocky, sub-rhombic, base crystal (photograph at 100X and elemental spectrum) 

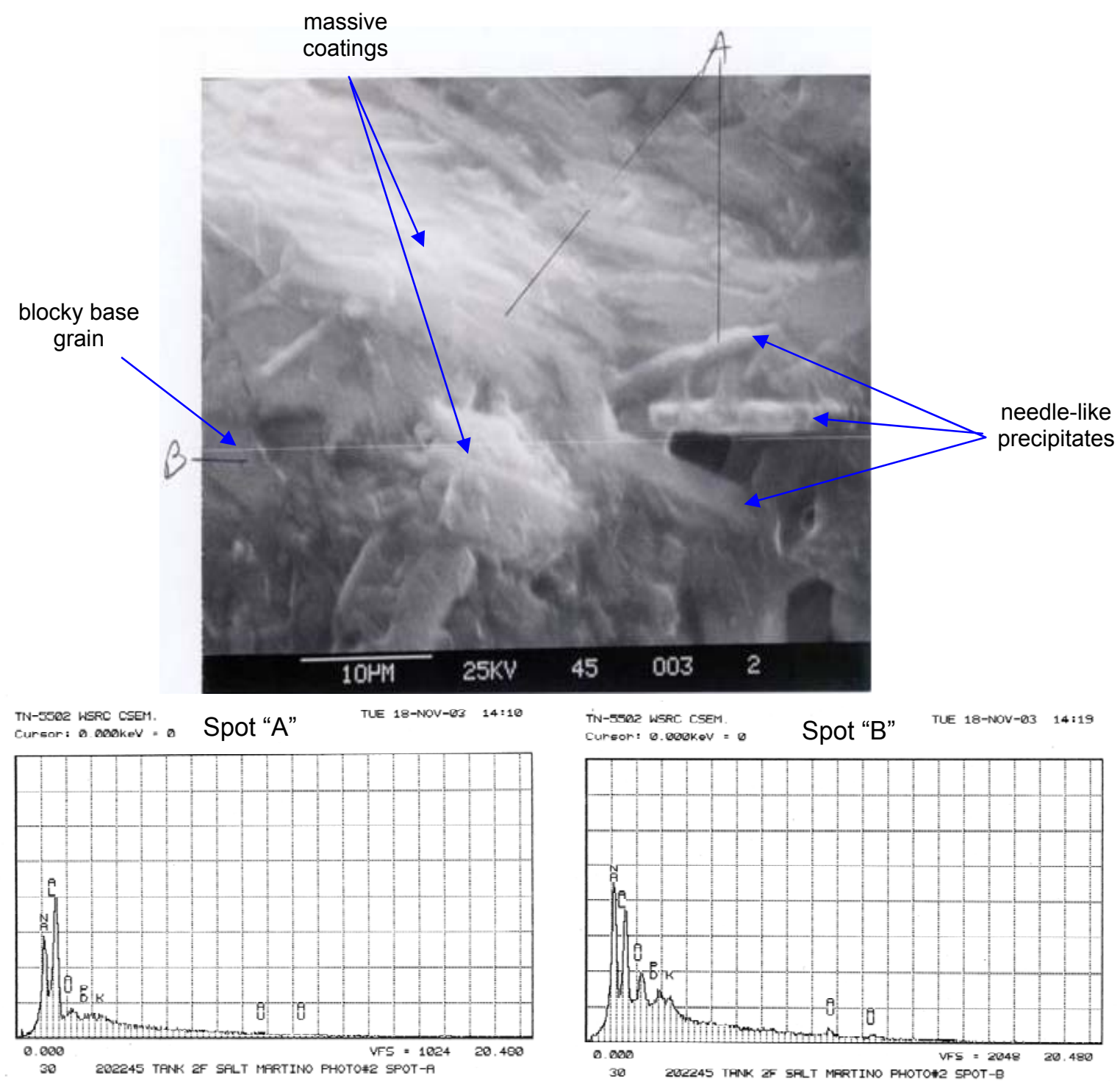

Figure 25: Examination of blocky base crystal and finer grained precipitate coatings (photograph at 2000X and elemental spectra) 
WSRC-TR-2004-00131

Revision 0

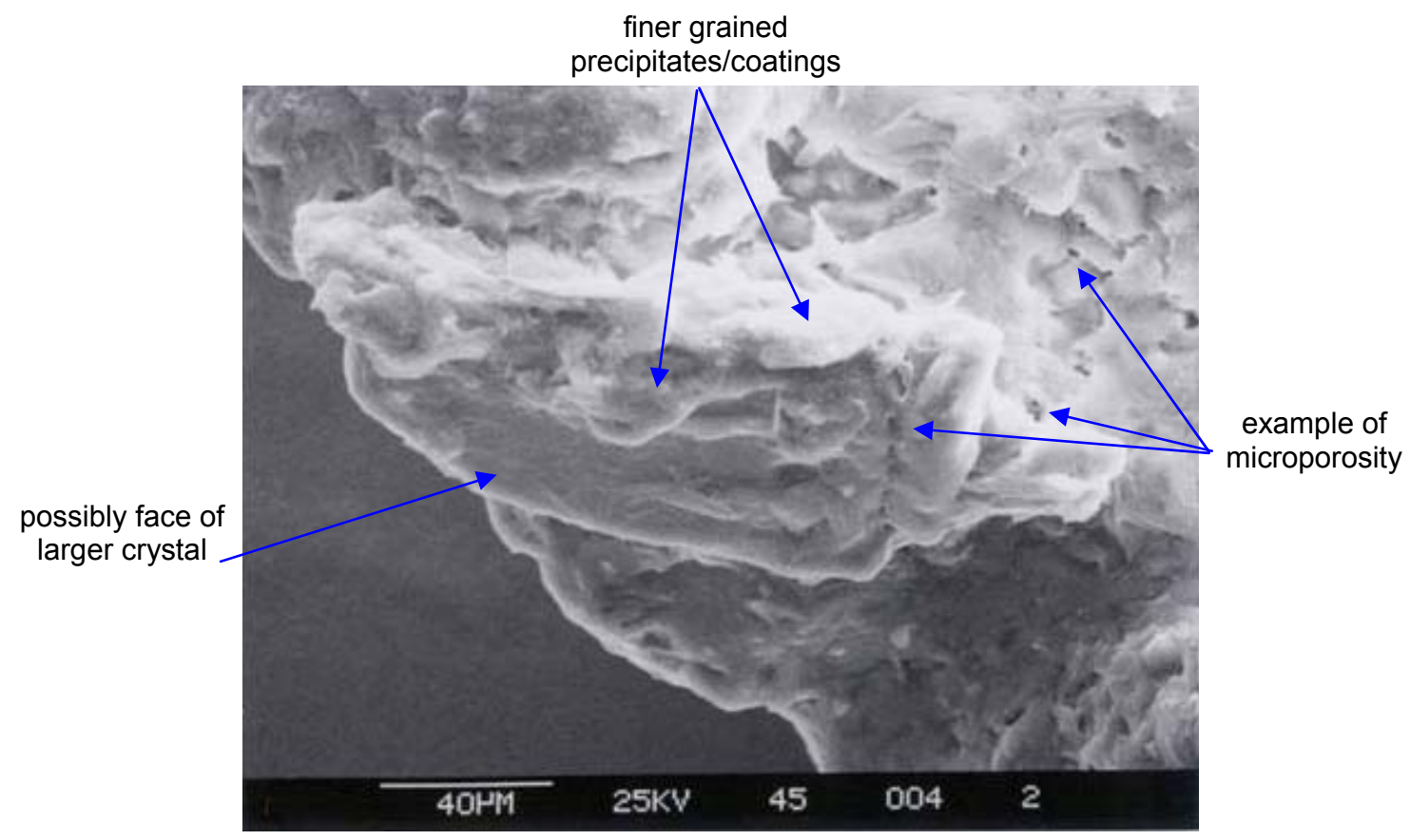

Figure 26: Example of porosity in Tank 2F Salt (500X)

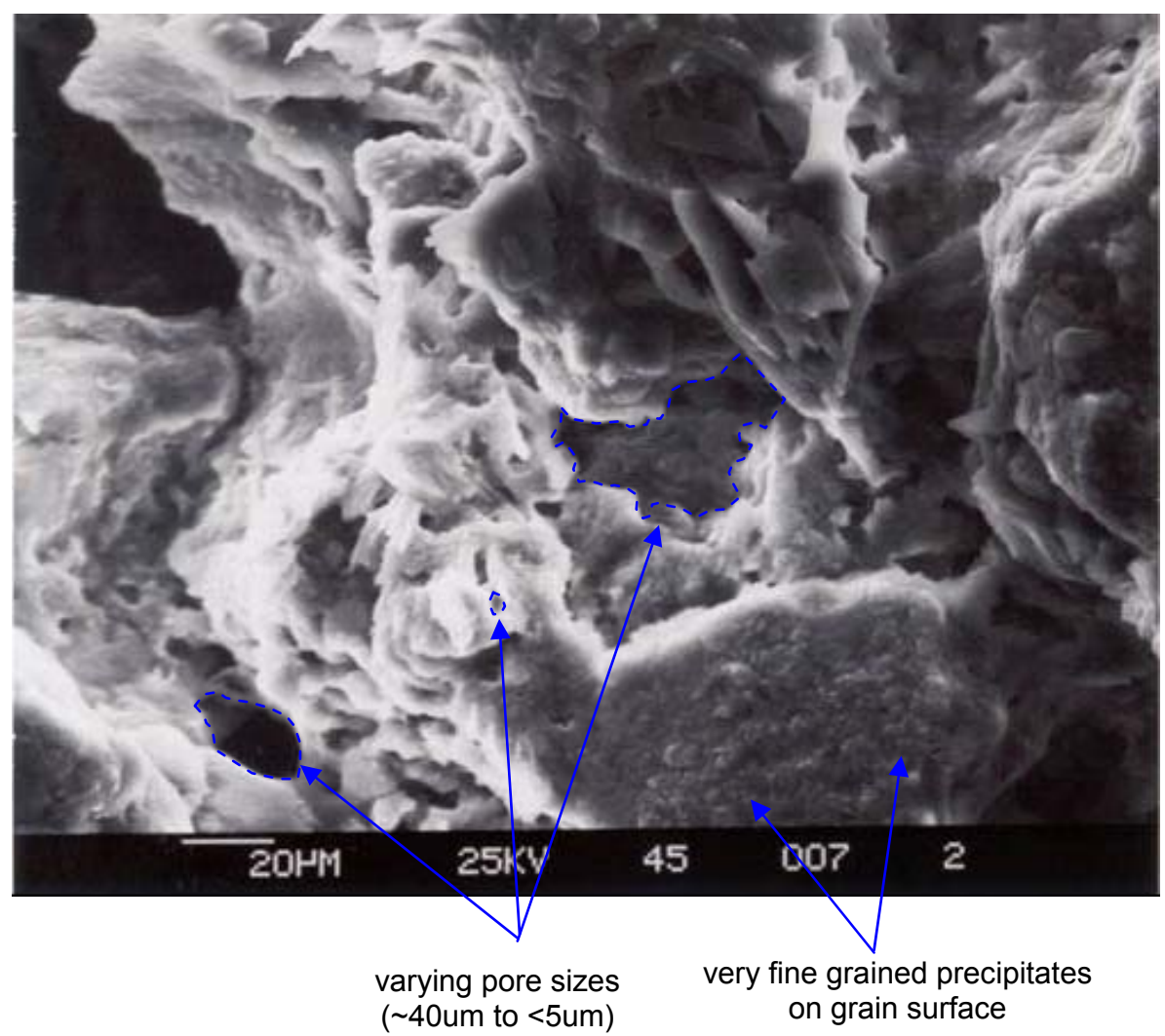

Figure 27: Varying size and shape of porosity (same view as Figure 23 but higher magnification -- 500X) 


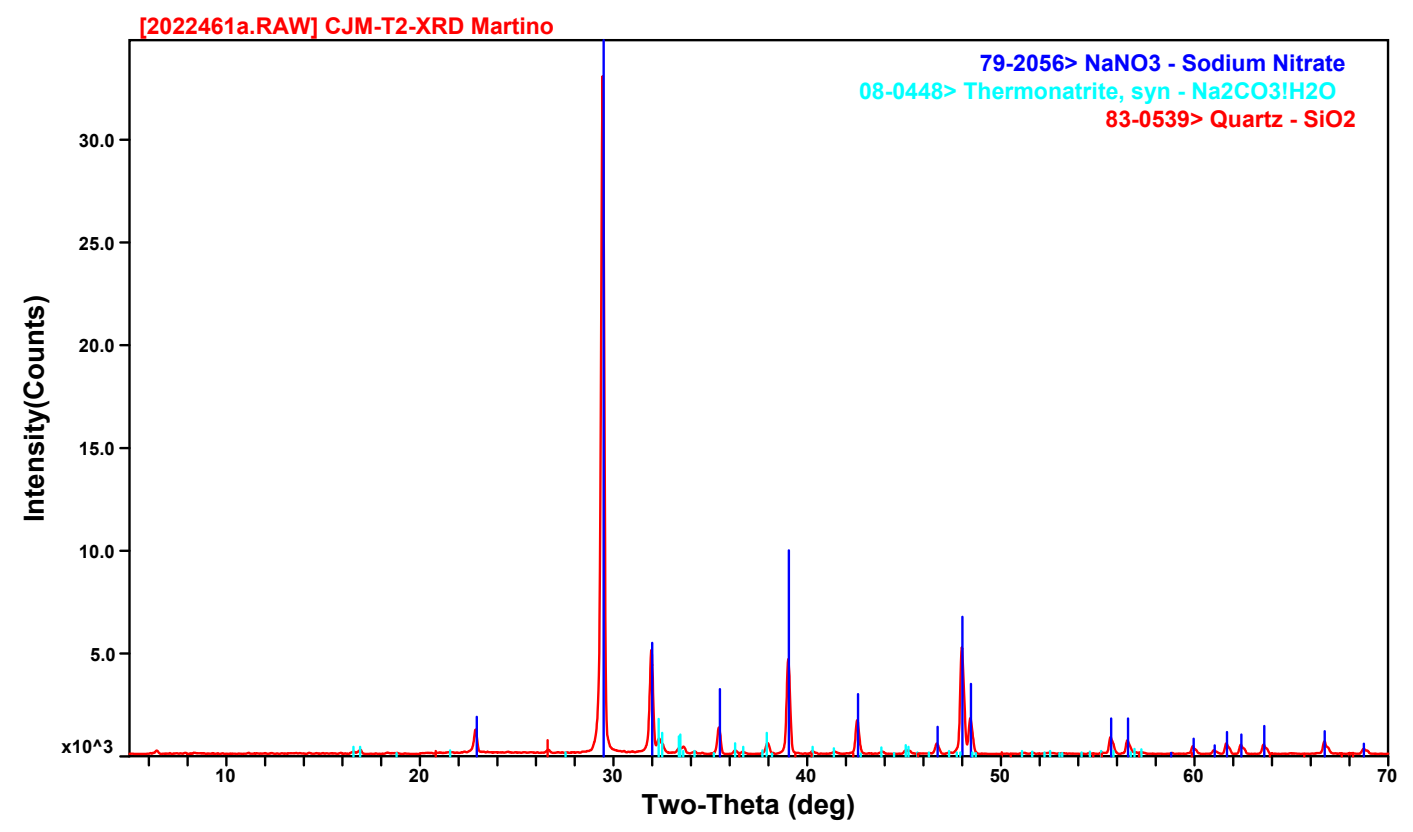

Figure 28: XRD of Tank 2F saltcake

\section{Simulated Saltcake}

A simulated saltcake has been examined with the petrographic microscope to evaluate disaggregation methods and to observe the nature of the crystals. The petrographic microscope allows for the observation of elements within the salt crystals, as apposed to SEM, which allows only for the observation of the crystal surfaces. The saltcake simulant contained sodium salts in the following rough dry composition: $75 \%$ nitrates, $10 \%$ carbonates, $10 \%$ sulfates, and $5 \%$ other salts (hydroxides, nitrites, and aluminates). The samples were disaggregated by sonicating in either mineral oil or a solution saturated with sodium salts. Disaggregation in mineral oil was less effective than in aqueous solution, but precipitation of secondary crystals from the aqueous solution complicated interpretation.

Figure 29 shows the typical range of grain sizes, about $0.1 \mathrm{~mm}$ to $1.5 \mathrm{~mm}$. The crystals are generally rounded, though some do exhibit distinct crystal faces (those labeled A in Figure 29). The crystals contain abundant fluid inclusions as shown in Figure 30. The large inclusion is about $0.2 \mathrm{~mm}$ in diameter. The spherical objects in each inclusion are vapor bubbles that indicate the crystals precipitated at an elevated temperature. Fluid in the inclusions is representative of fluid from which the crystals precipitated. Thus, if actual high level waste salt contains a similar abundance of inclusions, this may be a source of cesium that remains within the salt as interstitial fluid is drained.

During examination of the salt simulant precipitates formed from the salt-saturated solution used to disaggregate the samples. These were needle-like crystals that initially precipitated at the edges of fluid droplets. These could be identified under the petrographic microscope, but identification may be difficult with SEM. 


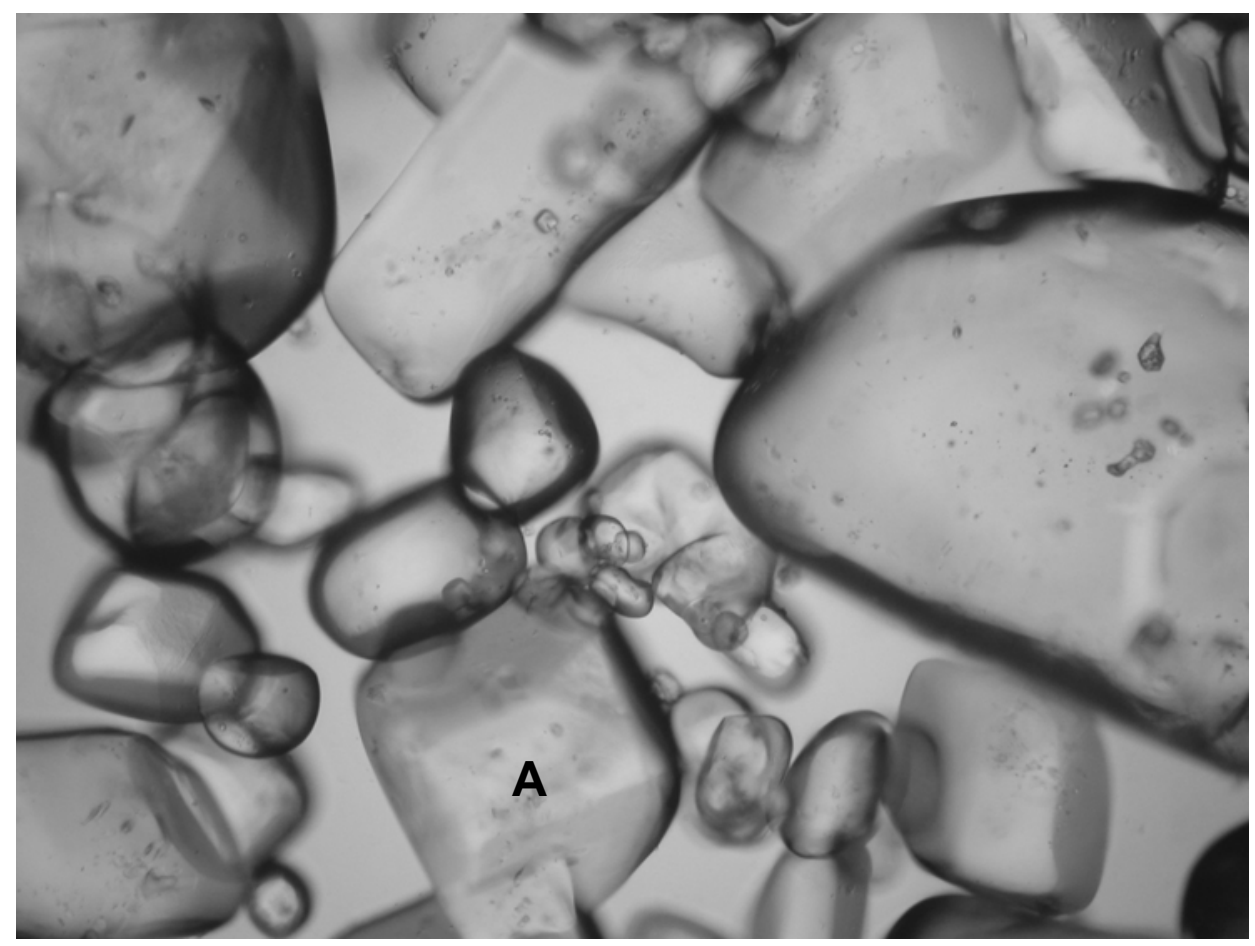

Figure 29: Photomicrograph of simulated high level waste salt. Crystal labeled "A" shows distinct crystal faces. Long dimension of photograph equals $2.2 \mathrm{~mm}$.

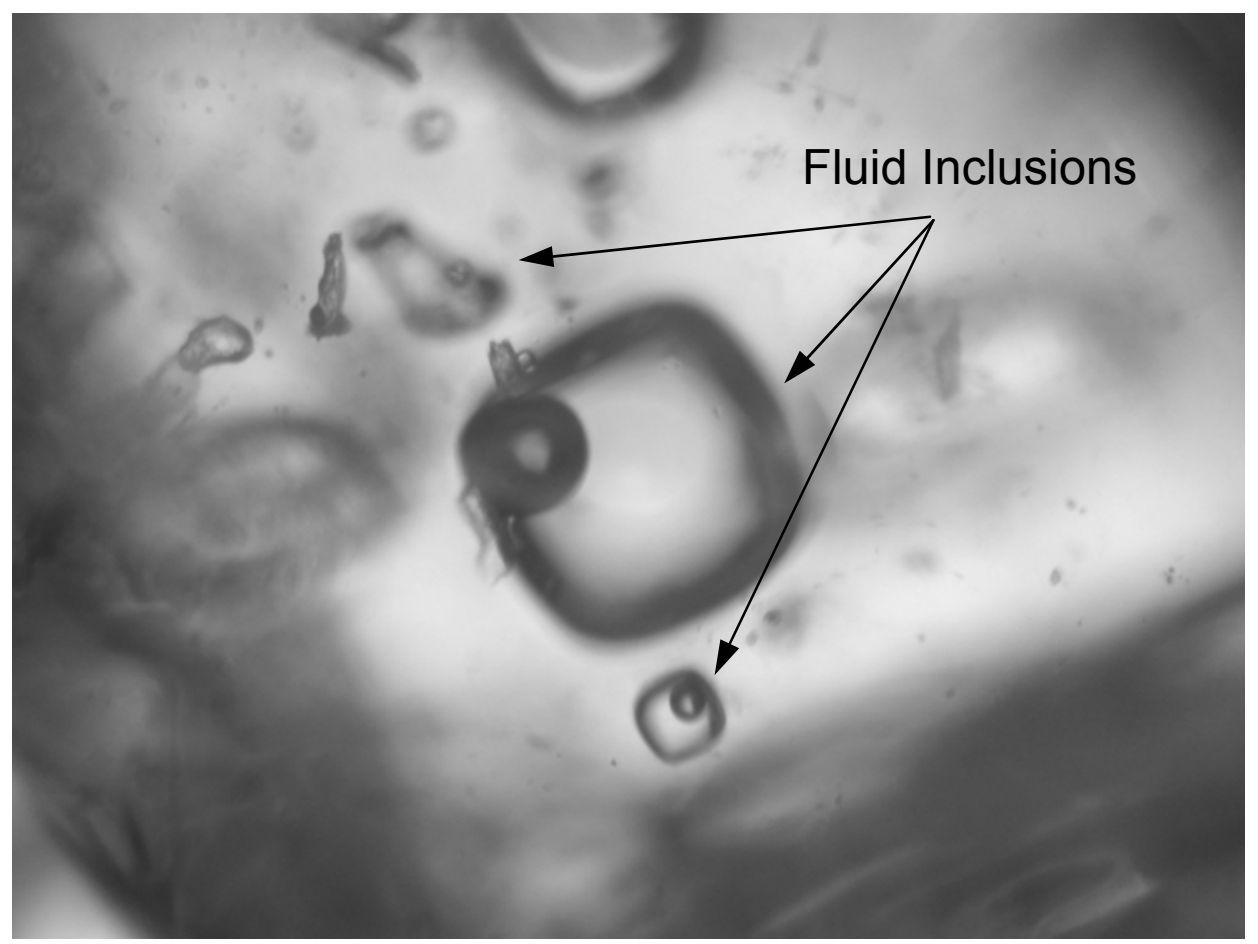

Figure 30: Photomicrograph of fluid inclusions in simulated salt crystal. Spherical objects inside inclusions are vapor bubbles. Long dimension of photograph equals $0.9 \mathrm{~mm}$. 


\section{$\underline{\text { Hydraulic Properties }}$}

An attempt to perform falling-head permeability tests ${ }^{5}$ of saltcake samples T2F-1-1 and T3F-1-3 was terminated after several weeks because the samples would not saturate with SIL (i.e., the samples were impermeable). Several adjustments were made to the falling head apparatus to ensure that the test equipment was not preventing SIL from entering the samples. The reason for the impermeability of the sample is not known, but could be due to several causes. Potentially, mixing between the SIL and interstitial liquid could have resulted in precipitation of salts that filled the porosity and prevented saturation of the sample. In the future samples should be drained as soon as possible after collection to minimize mixing between SIL and residual interstitial liquid. Also, salts may have precipitated due to the temperature difference between the tank and the shielded cells. Prompt drainage of samples collected from warm tanks (temp $>40^{\circ} \mathrm{C}$ ) will also minimize precipitation of salts from residual IL as the samples cool to the temperature in the laboratory. It is unlikely that the sample was intrinsically impermeable because the draining of interstitial liquid from T3F-1-4 was readily accomplished.

\section{Saltcake Draining}

Interstitial liquid extraction of sample T3F-1-4 removed about $20 \mathrm{~g}$ of IL from about $79 \mathrm{~g}$ of saltcake. Based on as-received sampling results this means $73 \%$ (vol/vol) of the IL in the sample was removed during IL extraction using 5" Hg vacuum. Even though T3F-1-4 was drained with a screen in place at the bottom of the sample, salt solids were evident in the drained material (see Figure 31)

\section{Dissolution of Drained Saltcake}

The Tank 3F sample whose draining was described in the previous section, sample T3F-1-4, was subsequently put through the dissolution protocol. At the start of the dissolution test, approximately $59 \mathrm{~g}$ of drained saltcake remained in T3F-1-4. The dissolution with DI water was performed using a relatively quick water introduction rate $(\sim 7 \mathrm{~mL} / \mathrm{min})$. Water was introduced to the top of the sample via a media bag and allowed to gravity drain through the sample and into a collection vessel. A series of six $5 \mathrm{~mL}$ sub-samples of the dissolved salt effluent were taken over the period of the dissolution process, and the remainder of the liquid was collected as the bulk dissolved saltcake.

Figure 31 is a photo of, from left to right, the drained interstitial fluid and the six dissolved salt effluent sub-samples. The interstitial liquid had a blue tinge and the dissolved salt had a yellow tinge. The second and third sub-samples had a floating immiscible layer of dark brown liquid. Figure 32 is a photo of the $\sim 0.4 \mathrm{~mL}$ dark layer at the top surface of the $5.9 \mathrm{~mL}$ second effluent sub-sample. By comparison, the layer at the surface of the third sub-sample was much smaller, and no dark layer was evident in the other sub-samples or the interstitial liquid.

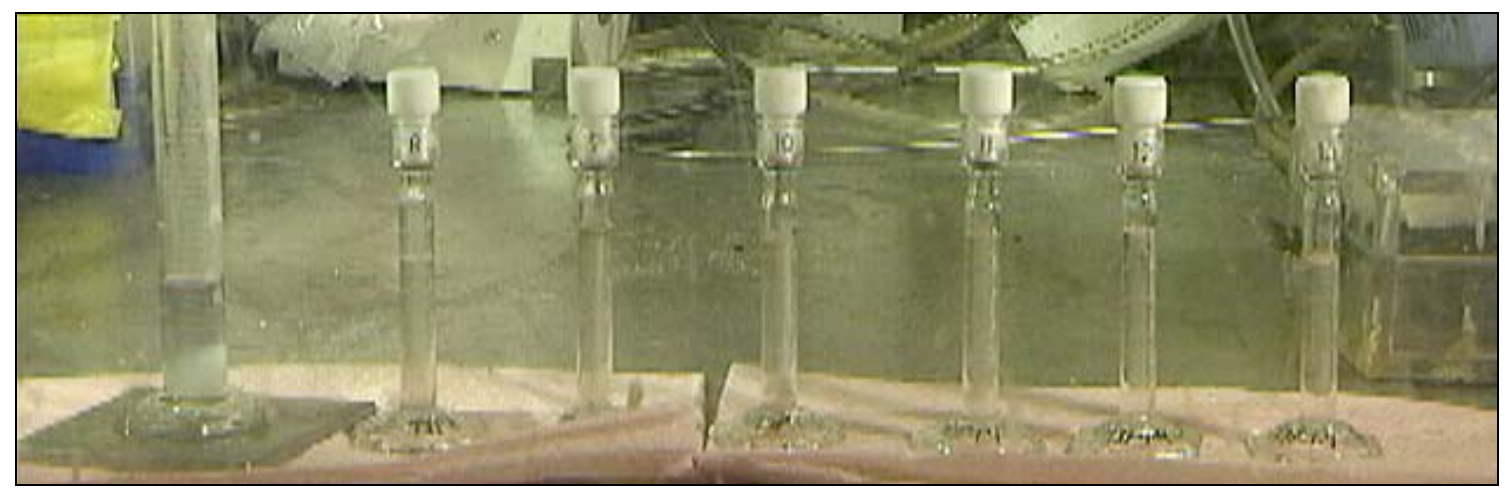

Figure 31: Tank 3F Interstitial Liquid (left) and Dissolved Samples (right) 


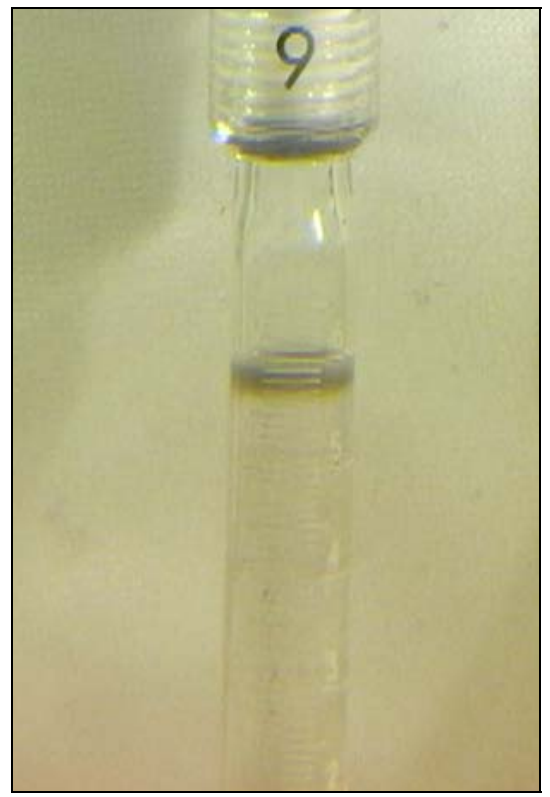

Figure 32: Layer of Dark Liquid in Second Sub-Sample of Tank 3F

Table 36 through Table 38 contain the data obtained during this test. It includes analysis of the unfiltered sub-samples (which included material from the dark layers, when present) and the filtered bulk dissolved salt effluent. Due to the fast flow rate and progressively worse water/salt contact, the density and sodium concentration decreased over the first four sub-samples. By the collection of the fifth sub-sample taken after a cumulative $122 \mathrm{~mL}$ of effluent, the effluent density was $1.00 \mathrm{~g} / \mathrm{mL}$ and the sodium concentration was low. The sixth sub-sample was not analyzed. From an inspection of the sample at the completion of the test, all salt was dissolved from within the sample tube. The composition of the samples that contained dark layers is not evidently different from those that did not. If the layers were organic, it is unlikely they would have been identified in the analytical suite used for these samples. Alternatively, it is possible that the floating liquid separated during the preparation of the analytical sample and was not included in the analyses.

As shown in Figure 33 , the ${ }^{137} \mathrm{Cs}$ concentration decreased throughout the dissolution test of the Tank $3 \mathrm{~F}$ drained saltcake sample. This decline in ${ }^{137} \mathrm{Cs}$ was significantly faster than the decline in sodium as the test proceeded. The salt effluent in the first sub-sample had a ${ }^{137} \mathrm{Cs}$ of $1.54 \mathrm{Ci} / \mathrm{gal}$ at $10.2 \mathrm{M}$ $\mathrm{Na}^{+}$and the fourth sub-sample had a ${ }^{137} \mathrm{Cs}$ of $0.06 \mathrm{Ci} /$ gal at $5.5 \mathrm{M} \mathrm{Na}^{+}$. Over the first four subsamples, the concentrations nitrate, sulfate, and carbonate in the dissolved salt effluent remained roughly constant. The bulk dissolved salt effluent had a ${ }^{137} \mathrm{Cs}$ of $0.13 \mathrm{Ci} / \mathrm{gal}$ at $3.3 \mathrm{M} \mathrm{Na}^{+}$, corresponding to $0.24 \mathrm{Ci} / g a l$ at $6 \mathrm{M} \mathrm{Na}^{+}$. The total alpha in the content of the filtered bulk salt effluent was $11 \mathrm{nCi} / \mathrm{mL}$.

The purpose of collecting sub-samples at various stages of the flow-through salt dissolution is to investigate the extent of selective dissolution. Previous centrifuge-tube batch dissolution tests on Tank $31 \mathrm{H}$ saltcake showed that individual salt components could be more or less concentrated at different stages of total saltcake dissolution. ${ }^{7}$ Similar is true for the flow-through dissolution of drained saltcake, though the separation was not as extreme as it was for the complete mixing conditions of Tank $31 \mathrm{H}$ batch contact tests. For the drained Tank $3 \mathrm{~F}$ saltcake flow through dissolution test, it was clear that the components partitioned to the interstitial liquid (nitrite, hydroxide, aluminate, and cesium) were also contained in the effluent from the first stages of dissolution in much greater quantities than from ensuing stages of dissolution. The primary components of the solid saltcake lattice, the nitrate, carbonate, and sulfate, were contained in the effluent in roughly constant quantities during the major period of saltcake dissolution. 

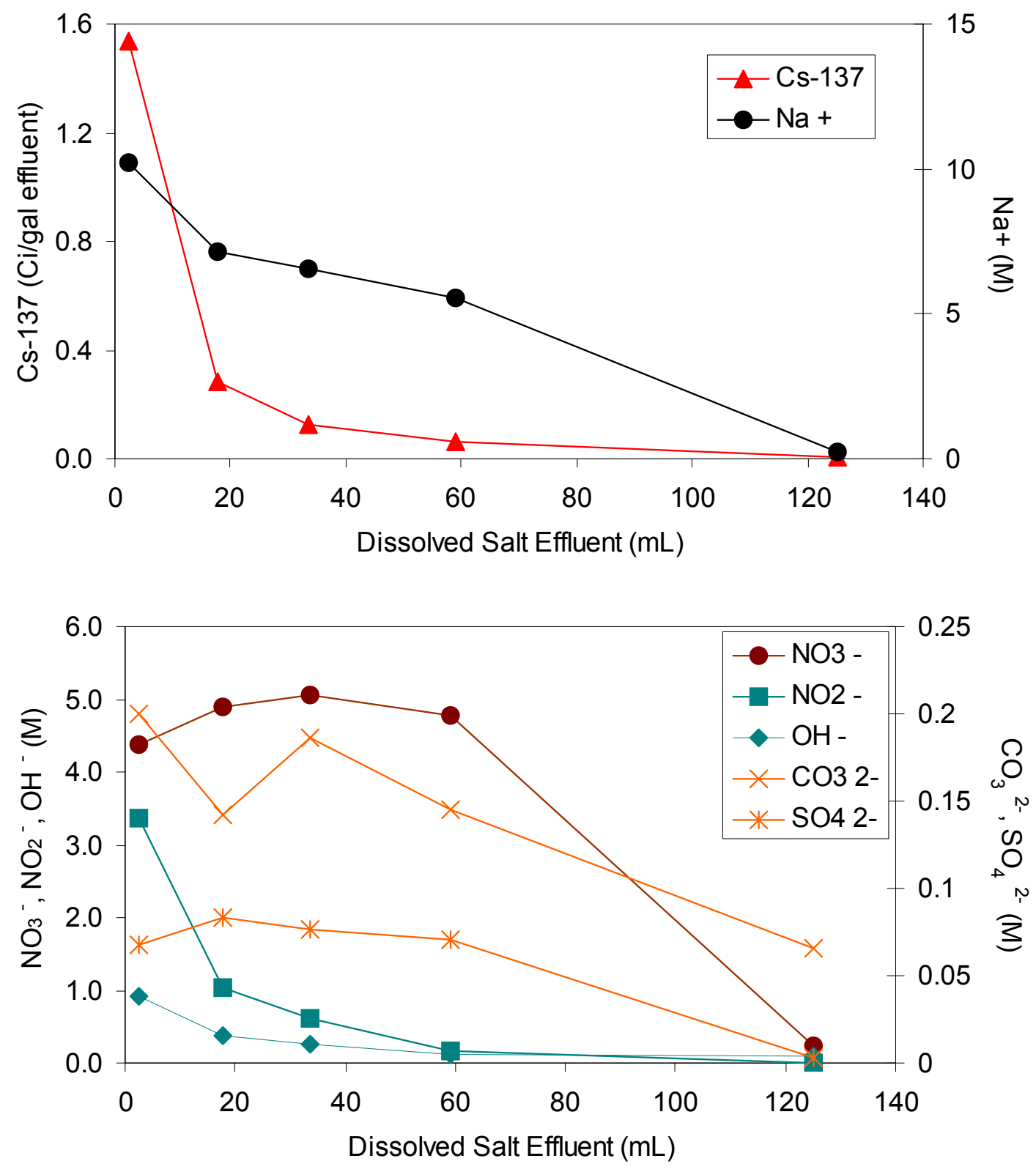

Figure 33: T3F-1-4 flow-through dissolution profiles for ${ }^{137} \mathrm{Cs}$ and $\mathrm{Na}^{+}$(top), and anions (bottom)

Perhaps the most significant observation for the dissolution of drained saltcake was that the ${ }^{137} \mathrm{Cs}$ concentration of the dissolved salt effluent was highest at the early stages of the test. This phenomenon observed during flow-through dissolution testing is consistent with some of the observed cesium behavior of the 2003 Tank $41 \mathrm{H}$ salt dissolution campaign. ${ }^{8}$ Analysis of the top 26 inches of drained Tank $41 \mathrm{H}$ saltcake prior to dissolution indicated that a salt solution $\left(6 \mathrm{M}\left[\mathrm{Na}^{+}\right]\right)$with $\mathrm{a}^{137} \mathrm{Cs}$ of 0.07 to $0.1 \mathrm{Ci} / \mathrm{gal}$. would be produced if it all dissolved homogeneously. Actual Tank $41 \mathrm{H}$ dissolution experience, however, resulted in a ${ }^{137} \mathrm{Cs}$ of $0.38 \mathrm{Ci} / g a l$. at $8 \mathrm{M} \mathrm{Na}^{+}$. The salt that was dissolved in Tank $41 \mathrm{H}$ passed through a large portion of the remaining saltcake, mixing with interstitial liquid and increasing in cesium concentration. In this aspect, the in-tank dissolution of Tank $41 \mathrm{H}$ saltcake is similar to the early stages of this flow-through dissolution tests.

In the dissolution of drained saltcake samples, some sub-samples failed to attain the LCS target specific gravity of $1.3 \mathrm{~g} / \mathrm{mL}$ and the target $\left[\mathrm{Na}^{+}\right]$of $6 \mathrm{M}$. This result is not an indication that salt 
dissolution will not lead to solutions that meet those targets. This occurred because the flow through the sample is relatively fast, not allowing for enough contact time between the dissolution fluid and the saltcake. As the test proceeded, the bed of salt became progressively smaller and it is likely that channeling increased. Compared to a full tank, factors such as channeling, temperature changes, and layering effects cannot be mimicked at this scale. In full-scale in-tank dissolution schemes, the salt contact time will be on the order of hours to days rather than the seconds to minutes encountered in these tests. Furthermore, on-line specific gravity measurements could readily ensure complete saturation of the effluent.

\section{Conclusions}

This report provides details of the characterization of the Tank 3F saltcake samples (T3F-1-1, T3F-13 , and T3F-1-4, corresponding to FTF-223, 224, and 225, respectively) pulled in August 2003 and the Tank 2F saltcake (T2F-1-1) and supernate (FTF-245 and 246) samples pulled in August and September 2003.

The three Tank 3F core samples contained a total of approximately 600 grams of saltcake with a density of $2.07 \mathrm{~g} / \mathrm{cm}^{3}$ and an estimated 170 grams of free liquid with a density of 1.47 to $1.52 \mathrm{~g} / \mathrm{cm}^{3}$. The saltcake samples differed in appearance and texture, and as-received water contents of the samples varied from $5.1 \mathrm{wt} \%$ in T3F-1-3 to $16.8 \mathrm{wt} \%$ in T3F-1-4. The ${ }^{137} \mathrm{Cs}$ activities of the bottom portions of undrained bulk saltcake in samples T3F-1-1 and T3F-1-4 were 1.5 $\mathrm{Ci}$ and $3.5 \mathrm{Ci}$ per gallon of saltcake, respectively. This roughly corresponds to the difference in liquid content in the samples. The sum of the ${ }^{238} \mathrm{Pu},{ }^{239 / 240} \mathrm{Pu}$, and ${ }^{241} \mathrm{Am}$ activities of the bottoms of undrained bulk saltcake in samples T3F-1-1 and T3F-1-4 were $9.6 \mathrm{E}+3 \mathrm{pCi} / \mathrm{g}$ and $8.9 \mathrm{E}+3 \mathrm{pCi} / \mathrm{g}$, respectively. The interstitial liquid drained from sample T3F-1-4 had a density of $1.49 \mathrm{~g} / \mathrm{cm}^{3}$, a soluble solids content of $50.2 \mathrm{wt} \%$, a ${ }^{137} \mathrm{Cs}$ activity of $7.1 \mathrm{Ci} / \mathrm{gal}$., and a ${ }^{238} \mathrm{Pu},{ }^{239 / 240} \mathrm{Pu}$, and ${ }^{241} \mathrm{Am}$ total activity of $1.15 \mathrm{E}+4 \mathrm{pCi} / \mathrm{mL}$. Although the ${ }^{137} \mathrm{Cs}$ activity in the interstitial liquid matched that of the free liquid samples, there were large differences in the measurement for sparingly soluble radionuclides (uranium, plutonium, americium, strontium, etc.) in these filtered liquids.

The Tank $2 \mathrm{~F}$ core sample contained hard-packed granular saltcake with a density of $2.04 \mathrm{~g} / \mathrm{cm}^{3}$ and a water content of $6.2 \mathrm{wt} \%$. The ${ }^{137} \mathrm{Cs}$ activitiy of the undrained bulk saltcake was $0.72 \mathrm{Ci}$ per gallon of saltcake and the ${ }^{238} \mathrm{Pu},{ }^{239 / 240} \mathrm{Pu}$, and ${ }^{241} \mathrm{Am}$ activities summed to $2.1 \mathrm{E}+4 \mathrm{pCi} / \mathrm{g}$. The Tank $2 \mathrm{~F}$ supernatant liquid samples (FTF-245 and 246), taken from a trough below riser 1, was blue/green with only a small amount of visible insoluble solids. They had a density of $1.50 \mathrm{~g} / \mathrm{cm}^{3}$, a water content of $47.8 \mathrm{wt} \%$, a ${ }^{137} \mathrm{Cs}$ activity of $6.2 \mathrm{Ci} / \mathrm{gal}$. The content of the plutonium and americium isotopes were below the analytical detection limits.

Salt from Tanks $2 \mathrm{~F}$ and $3 \mathrm{~F}$ was investigated by scanning electron microscopy, providing information on the salt grain size and morphology. Microporosity was observed within the saltcake grains. The light microscopy of disaggregated simulated saltcake revealed fluid inclusions.

A flow-through dissolution test was performed on the drained saltcake sample T3F-1-4. The ${ }^{137} \mathrm{Cs}$ concentration was highest in the effluent from the earliest stages of dissolution and decreased during subsequent stages of the dissolution test. As expected, this decline in ${ }^{137} \mathrm{Cs}$ was significantly faster than the decline in sodium as the test proceeded.

\section{Quality Assurance}

This work satisfies the requirements of the original task technical and quality assurance plan. ${ }^{9}$ Laboratory Notebooks WSRC-NB-2003-00072, WSRC-NB-2003-00175, WSRC-NB-2003-00176, WSRC-NB-2003-00199, and various Analytical Development Section notebooks contain the experimental data. 


\section{Acknowledgements}

The authors thank the following for their important contributions to this project: John Sessions, Glen Johnson, and Dennis Conrad of the Closure Business Unit; Nancy Gregory and Sharon Smith in SRTC Waste Processing Technology; Monica Jenkins, Mona Galloway, Monica Miller, Rita Sullivan, Carolyn Conley, Dave Keel, Ron Blessing and many others in SRTC Shielded Cells Operations; Tom Nance and Dan Krementz of SRTC Remote Specialty Equipment; Curt Sexton of the SRTC Glassblowing Shop; Leigh Brown, Dave Diprete, Ceci Diprete, Theresa Eddy, June Hart, Damon Click, Bill Boyce, Mira Malek, Chuck Coleman, Beverly Burch, John Young, Amy Ekechukwu, Robert Ray, Michael Whitaker, Art Jurgensen, Dave Missimer, Wilson Smith, Marti Finney, and many technicians of SRTC Analytical Development.

\section{References}

1 J. R. Sessions, "Saltcake Characterization to Support Closure Activities," CBU-SPT-2003-00126, Rev. 0, July 17, 2003.

${ }^{2}$ D. T. Conrad, "LCS Sampling and Analysis Plan for Process Validation," CBU-SPT-2003-00164, Rev. 0, September 9, 2003.

${ }^{3}$ A. Q. Goslen and D. H. McGuire, "History of Waste Tank 2: 1955 through 1974," DPSPU 83-11-5, December 1983.

${ }^{4}$ G. P. Flach, "Porous Medium Analysis of Interstitial Liquid Removal from Tank 41 and Tank 3 (U)," WSRC-TR-2003-00533, Rev. 0, February 2004.

${ }^{5}$ R. L. Nichols and C. J. Martino, "Hydraulic Properties of Saltcake Samples from Tank 41H (U)" WSRC-TR-2003-00543, Rev. 0, January 2004.

${ }^{6}$ C. J. Martino, R. L. Nichols, D. J. McCabe, and E. K. Hansen, "Tank 38H Saltcake Core and Supernate Sample Analysis," WSRC-TR-2004-00129, Rev. 0, March 24, 2004.

${ }^{7}$ C. J. Martino and M. R. Poirier, "Tank 31H Saltcake Dissolution Tests," WSRC-TR-2002-00388, Rev. 0, February 27, 2003.

${ }^{8}$ L. B. Romanowski, "Tank 41 Low Curie Salt Process History and Data Analysis," CBU-SPT-200300224, Rev. 0, December 18, 2003.

${ }^{9}$ R. L. Nichols and C. J. Martino, "Task Technical and Quality Assurance Plan for the Characterization of Drained Low-Curie Saltcake," WSRC-RP-2003-00319, Rev. 1, June 3, 2003. 


\section{Appendix}

Table 14: Tank 3F Undrained Bulk Saltcake ICP-ES results (g/100g)

\begin{tabular}{|c|r|r|r|r|}
\hline Sample: & \multicolumn{2}{|c|}{ T3F-1-1 } & \multicolumn{2}{c|}{ T3F-1-4 } \\
\hline (g/100g) & \multicolumn{1}{|c|}{ Average } & St. Dev. & \multicolumn{1}{c|}{ Average } & St. Dev. \\
\hline $\mathrm{Ag}$ & $<3.86 \mathrm{E}-04$ & & $<3.86 \mathrm{E}-04$ & \\
\hline $\mathrm{Al}$ & $1.74 \mathrm{E}-01$ & $8 \mathrm{E}-03$ & $4.19 \mathrm{E}-01$ & $4.3 \mathrm{E}-02$ \\
\hline $\mathrm{B}$ & $<4.17 \mathrm{E}-02$ & & $<4.17 \mathrm{E}-02$ & \\
\hline $\mathrm{Ba}$ & $1.39 \mathrm{E}-03$ & $5.1 \mathrm{E}-04$ & $5.43 \mathrm{E}-04$ & $8.4 \mathrm{E}-05$ \\
\hline $\mathrm{Ca}$ & $<1.17 \mathrm{E}-02$ & & $<1.17 \mathrm{E}-02$ & \\
\hline $\mathrm{Cd}$ & $<5.15 \mathrm{E}-04$ & & $<5.15 \mathrm{E}-04$ & \\
\hline $\mathrm{Ce}$ & $<6.39 \mathrm{E}-03$ & & $<6.38 \mathrm{E}-03$ & \\
\hline $\mathrm{Cr}$ & $7.72 \mathrm{E}-03$ & $4.5 \mathrm{E}-04$ & $1.19 \mathrm{E}-02$ & $6.6 \mathrm{E}-03$ \\
\hline $\mathrm{Cu}$ & $<7.99 \mathrm{E}-04$ & & $<7.98 \mathrm{E}-04$ & \\
\hline $\mathrm{Fe}$ & $1.57 \mathrm{E}-02$ & $6.7 \mathrm{E}-03$ & $1.8 \mathrm{E}-02$ & $2.7 \mathrm{E}-02$ \\
\hline $\mathrm{Gd}$ & $<6.95 \mathrm{E}-04$ & & $<6.95 \mathrm{E}-04$ & \\
\hline $\mathrm{K}$ & $<2.45 \mathrm{E}-01$ & & $3.23 \mathrm{E}-01$ & $4.58 \mathrm{E}-03$ \\
\hline $\mathrm{La}$ & $<5.15 \mathrm{E}-04$ & & $<5.15 \mathrm{E}-04$ & \\
\hline $\mathrm{Li}$ & $<2.19 \mathrm{E}-03$ & & $<2.19 \mathrm{E}-03$ & \\
\hline $\mathrm{Mg}$ & $<1.60 \mathrm{E}-03$ & & $<1.60 \mathrm{E}-03$ & \\
\hline $\mathrm{Mn}$ & $1.11 \mathrm{E}-03$ & $9.6 \mathrm{E}-05$ & $</=6.81 \mathrm{E}-04$ & \\
\hline $\mathrm{Mo}$ & $<5.26 \mathrm{E}-03$ & & $</=5.93 \mathrm{E}-03$ & \\
\hline $\mathrm{Na}$ & $2.54 \mathrm{E}+01$ & $2 \mathrm{E}-01$ & $2.39 \mathrm{E}+01$ & $6 \mathrm{E}-01$ \\
\hline $\mathrm{Ni}$ & $<1.93 \mathrm{E}-03$ & & $3.44 \mathrm{E}-03$ & $2.58 \mathrm{E}-03$ \\
\hline $\mathrm{P}$ & $<1.26 \mathrm{E}-02$ & & $2.36 \mathrm{E}-02$ & $4.2 \mathrm{E}-03$ \\
\hline $\mathrm{Pb}$ & $<6.34 \mathrm{E}-03$ & & $<6.33 \mathrm{E}-03$ & \\
\hline $\mathrm{S}$ & $3.57 \mathrm{E}-01$ & $9.0 \mathrm{E}-02$ & $7.14 \mathrm{E}-01$ & $7.1 \mathrm{E}-02$ \\
\hline $\mathrm{Sb}$ & $<3.89 \mathrm{E}-03$ & & $<3.89 \mathrm{E}-03$ & \\
\hline $\mathrm{Si}$ & $3.96 \mathrm{E}-03$ & $3.7 \mathrm{E}-04$ & $3.14 \mathrm{E}-03$ & $3.8 \mathrm{E}-04$ \\
\hline $\mathrm{Sn}$ & $<6.31 \mathrm{E}-03$ & & $<6.31 \mathrm{E}-03$ & \\
\hline $\mathrm{Sr}$ & $<2.58 \mathrm{E}-03$ & & $<2.57 \mathrm{E}-03$ & \\
\hline $\mathrm{Ti}$ & $<1.55 \mathrm{E}-04$ & & $<1.54 \mathrm{E}-04$ & \\
\hline $\mathrm{V}$ & $<3.02 \mathrm{E}-04$ & & $4.34 \mathrm{E}-04$ & $2.0 \mathrm{E}-05$ \\
\hline $\mathrm{Zn}$ & $<1.42 \mathrm{E}-03$ & & $<1.41 \mathrm{E}-03$ & \\
\hline $\mathrm{Zr}$ & $<3.09 \mathrm{E}-04$ & & $<3.09 \mathrm{E}-04$ & \\
\hline & & & & \\
\hline
\end{tabular}


Table 15: Tank 3F Undrained Bulk Saltcake AA results $(\mathrm{g} / 100 \mathrm{~g})$

\begin{tabular}{|c|c|c|c|c|}
\hline Sample: & \multicolumn{2}{|c|}{ T3F-1-1 } & \multicolumn{2}{|c|}{ T3F-1-4 } \\
\hline$(g / 100 g)$ & Average & St. Dev. & Average & St. Dev. \\
\hline As & \multicolumn{2}{|l|}{$<1.3 E-04$} & \multicolumn{2}{|l|}{$<1.3 E-04$} \\
\hline Cs & $1.08 \mathrm{E}-03$ & $3.5 \mathrm{E}-04$ & 1.97E-03 & 1.7E-04 \\
\hline K & 1.78E-02 & $1.2 \mathrm{E}-03$ & 1.51E-02 & $1.2 \mathrm{E}-03$ \\
\hline $\mathrm{Se}$ & $<1.3 E-04$ & & $<1.3 E-04$ & \\
\hline $\mathrm{Hg}$ & 7.35E-04 & $5.0 \mathrm{E}-05$ & $<2.8 E-04$ & \\
\hline
\end{tabular}

Table 16: Tank 3F Undrained Bulk Saltcake IC Anions, wet chemistry titration, and TIC/TOC results $(\mathrm{g} / 100 \mathrm{~g})$

\begin{tabular}{|c|c|c|c|c|}
\hline Sample: & \multicolumn{2}{|c|}{ T3F-1-1 } & \multicolumn{2}{|c|}{ T3F-1-4 } \\
\hline (g/100g) & Average & St. Dev. & Average & St. Dev. \\
\hline $\mathrm{NO}_{3}{ }^{-}$ & $5.99 \mathrm{E}+01$ & $2.3 \mathrm{E}+00$ & $4.23 \mathrm{E}+01$ & $6.1 \mathrm{E}+00$ \\
\hline $\mathrm{NO}_{2}{ }^{-}$ & $1.40 \mathrm{E}+00$ & $2 \mathrm{E}-02$ & $3.27 \mathrm{E}+00$ & $2.2 \mathrm{E}-01$ \\
\hline $\mathrm{SO}_{4}{ }^{2-}$ & 7.60E-01 & 1.91E-01 & $1.98 \mathrm{E}+00$ & $2.5 \mathrm{E}-01$ \\
\hline $\mathrm{PO}_{4}{ }^{3-}$ & $<4.65 E-01$ & & $<3.84 E-01$ & \\
\hline $\mathrm{Cl}^{-}$ & $<9.30 E-02$ & & $<7.68 E-02$ & \\
\hline $\mathrm{F}^{-}$ & $<9.30 E-02$ & & $<7.68 E-02$ & \\
\hline $\mathrm{C}_{2} \mathrm{O}_{4}{ }^{2-}$ & $<4.65 E-01$ & & $<3.84 E-01$ & \\
\hline $\mathrm{CHO}_{2}^{-}$ & $<4.65 E-01$ & & $<3.84 E-01$ & \\
\hline Free $\mathrm{OH}^{-}$ & 7.51E-01 & $3.0 \mathrm{E}-01$ & $2.50 \mathrm{E}+00$ & 7.6E-01 \\
\hline $\mathrm{CO}_{3}{ }^{2-}$ (titration) & $<5.58 E-01$ & & $</=4.80 E-01$ & \\
\hline $\mathrm{CO}_{3}{ }^{2-}(\mathrm{TIC})^{\mathrm{a}}$ & $7.50 \mathrm{E}-01$ & $3.40 \mathrm{E}-01$ & $9.81 \mathrm{E}-01$ & 1.59E-01 \\
\hline $\mathrm{TOC}^{\mathrm{a}}$ & 3.61E-01 & 7.7E-02 & $2.70 \mathrm{E}-01$ & $1.20 \mathrm{E}-01$ \\
\hline
\end{tabular}

Note a: A blank had measurable levels of TIC and TOC, with TOC at $\sim 50 \%$ of the typical values measured for the samples.

Table 17: Tank 3F Undrained Bulk Saltcake rad. chem. results ( $\mathrm{pCi} / \mathrm{g})$

\begin{tabular}{|c|c|c|c|c|}
\hline Sample: & \multicolumn{2}{|c|}{ T3F-1-1 } & \multicolumn{2}{|c|}{ T3F-1-4 } \\
\hline$(\mathrm{pCi} / \mathrm{g})$ & Average & St. Dev. & Average & St. Dev. \\
\hline${ }^{14} \mathrm{C}$ & $3.4 \mathrm{E}+03$ & -- & $4.5 E+03$ & -- \\
\hline${ }^{90} \mathrm{Sr}$ & $1.78 \mathrm{E}+06$ & $7.7 \mathrm{E}+05$ & $8.96 \mathrm{E}+05$ & $1.17 E+05$ \\
\hline${ }^{137} \mathrm{Cs}$ & $1.89 E+08$ & $1.2 \mathrm{E}+07$ & $4.47 E+08$ & $3.5 \mathrm{E}+07$ \\
\hline${ }^{238} \mathrm{Pu}$ & $5.69 \mathrm{E}+03$ & $1.79 \mathrm{E}+03$ & $4.51 \mathrm{E}+03$ & $2.57 E+03$ \\
\hline${ }^{239 / 240} \mathrm{Pu}^{\mathrm{a}}$ & $2.38 E+03$ & $5.2 E+02$ & $2.63 E+03$ & $7.1 \mathrm{E}+02$ \\
\hline${ }^{241} \mathrm{Am}^{\mathrm{a}}$ & $1.53 \mathrm{E}+03$ & $1.6 \mathrm{E}+02$ & $1.75 E+03$ & $4.6 \mathrm{E}+02$ \\
\hline Gross Alpha & $<1.48 E+06$ & & $<1.89 E+06$ & \\
\hline Gross Beta & $2.26 \mathrm{E}+08$ & $8 \mathrm{E}+06$ & $5.29 \mathrm{E}+08$ & $5.0 \mathrm{E}+07$ \\
\hline
\end{tabular}

Note a: A blank had levels of ${ }^{239 / 240} \mathrm{Pu}$ and ${ }^{241} \mathrm{Am}$ at $\sim 50 \%$ of the typical values measured for the samples. 
Table 18: Tank 3F Undrained Bulk Saltcake ICP-MS results $(\mathrm{g} / 100 \mathrm{~g})$

\begin{tabular}{|c|c|c|c|c|}
\hline Sample: & \multicolumn{2}{|c|}{ T3F-1-1 } & \multicolumn{2}{|c|}{ T3F-1-4 } \\
\hline$(g / 100 g)$ & Average & St. Dev. & Average & St. Dev. \\
\hline Mass 88 & $2.8 \mathrm{E}-05$ & $1.2 \mathrm{E}-05$ & $</=1.5 \mathrm{E}-05$ & $4.9 \mathrm{E}-06$ \\
\hline Mass 99 & 5.0E-04 & 3E-05 & $6.6 \mathrm{E}-04$ & $6 \mathrm{E}-05$ \\
\hline Mass 101 & 7.7E-05 & $8 \mathrm{E}-06$ & 6.6E-05 & $5 E-06$ \\
\hline Mass 129 & $<1.5 E-05$ & & $<1.5 E-05$ & \\
\hline Mass 133 & $6.1 \mathrm{E}-04$ & 4E-05 & 1.4E-03 & 1E-04 \\
\hline Mass 135 & 9.5E-05 & $1.1 \mathrm{E}-05$ & $1.8 \mathrm{E}-04$ & 2E-05 \\
\hline Mass 137 & 1.1E-03 & 4E-04 & 8.3E-04 & 9E-05 \\
\hline Mass 138 & $2.1 \mathrm{E}-04$ & $1.0 \mathrm{E}-04$ & 5.5E-05 & $6.4 \mathrm{E}-05$ \\
\hline Mass 230 & $<6.5 E-06$ & & $<6.5 E-06$ & \\
\hline Mass 231 & $<6.5 E-06$ & & $<6.5 E-06$ & \\
\hline Mass 232 & $<9.4 E-06$ & & $</=8.1 \mathrm{E}-06$ & $2.6 \mathrm{E}-06$ \\
\hline Mass 233 & $<6.5 E-06$ & & $<6.5 E-06$ & \\
\hline Mass 234 & $<6.5 E-06$ & & $<6.5 E-06$ & \\
\hline Mass 235 & $</=8.8 \mathrm{E}-06$ & $1.8 \mathrm{E}-06$ & $</=6.7 \mathrm{E}-06$ & 2E-07 \\
\hline Mass 236 & $<6.5 E-06$ & & $<6.5 E-06$ & \\
\hline Mass 237 & $<6.5 E-06$ & & $<6.5 E-06$ & \\
\hline Mass 238 & $1.76 \mathrm{E}-03$ & 3.3E-04 & 1.02E-03 & 1.5E-04 \\
\hline Mass 239 & $<6.5 E-06$ & & $<6.5 E-06$ & \\
\hline Mass 240 & $<6.5 E-06$ & & $<6.5 E-06$ & \\
\hline Mass 241 & $<6.5 E-06$ & & $<6.5 E-06$ & \\
\hline Mass 242 & $<6.5 E-06$ & & $<6.5 E-06$ & \\
\hline Mass 243 & $<6.5 E-06$ & & $<6.5 E-06$ & \\
\hline Mass 244 & $<6.5 E-06$ & & $<6.5 E-06$ & \\
\hline
\end{tabular}


Table 19: Tank 3F Free Liquid and Interstitial Liquid ICP-ES results (mg/L)

\begin{tabular}{|c|c|c|c|c|c|c|c|}
\hline Sample: & \multicolumn{2}{|c|}{ T3F-1-1 FL } & \multirow{2}{*}{ T3F-1-3 FL } & \multicolumn{2}{|c|}{ T3F-1-4 FL } & \multicolumn{2}{|c|}{ T3F-1-4 IL } \\
\hline$(\mathrm{mg} / \mathrm{L})$ & Average & St. Dev. & & Average & St. Dev. & Average & St. Dev. \\
\hline $\mathrm{Ag}$ & $<2.08 E+01$ & & $<2.24 E+01$ & $<2.16 E+01$ & & $<2.16 E+01$ & \\
\hline Al & $1.42 \mathrm{E}+04$ & $2 \mathrm{E}+02$ & $1.56 \mathrm{E}+04$ & $1.76 \mathrm{E}+04$ & $2 \mathrm{E}+02$ & $1.71 \mathrm{E}+04$ & $2 \mathrm{E}+02$ \\
\hline$B$ & $<2.25 E+03$ & & $<2.42 E+03$ & $<2.34 E+03$ & & $<2.34 E+03$ & \\
\hline $\mathrm{Ba}$ & $<2.08 E+01$ & & $<2.24 E+01$ & $<2.16 E+01$ & & $<2.16 E+01$ & \\
\hline $\mathrm{Be}$ & $<5.34 E+00$ & & $<5.76 E+00$ & $<5.56 E+00$ & & $<5.55 E+00$ & \\
\hline $\mathrm{Ca}$ & $<6.29 E+02$ & & $<6.77 E+02$ & $<6.54 E+02$ & & $<6.53 E+02$ & \\
\hline $\mathrm{Cd}$ & $<2.78 E+01$ & & $<2.99 E+01$ & $<2.89 E+01$ & & $<2.88 E+01$ & \\
\hline $\mathrm{Ce}$ & $<3.44 E+02$ & & $<3.71 E+02$ & $<3.58 E+02$ & & $<3.58 E+02$ & \\
\hline $\mathrm{Cr}$ & $2.64 \mathrm{E}+02$ & $7 \mathrm{E}+00$ & $2.74 \mathrm{E}+02$ & $3.05 \mathrm{E}+02$ & $7 \mathrm{E}+00$ & $3.01 \mathrm{E}+02$ & $8 \mathrm{E}+00$ \\
\hline $\mathrm{Cu}$ & $<4.30 E+01$ & & $<4.63 E+01$ & $<4.47 E+01$ & & $<4.47 E+01$ & \\
\hline $\mathrm{Fe}$ & $<3.05 E+01$ & & $<3.29 E+01$ & $<3.17 E+01$ & & $<3.17 E+01$ & \\
\hline $\mathrm{Gd}$ & $<3.75 E+01$ & & $<4.04 E+01$ & $<3.90 E+01$ & & $<3.89 E+01$ & \\
\hline $\mathrm{K}$ & $<1.32 E+04$ & & $<1.42 E+04$ & $<1.37 E+04$ & & $<1.37 E+04$ & \\
\hline La & $<2.78 E+01$ & & $<2.99 E+01$ & $<2.89 E+01$ & & $<2.88 E+01$ & \\
\hline $\mathrm{Li}$ & $<1.18 E+02$ & & $<1.27 E+02$ & $<1.23 E+02$ & & $<1.23 E+02$ & \\
\hline $\mathrm{Mg}$ & $<8.60 E+01$ & & $<9.27 E+01$ & $<8.95 E+01$ & & $<8.94 E+01$ & \\
\hline $\mathrm{Mn}$ & $<3.05 E+01$ & & $<3.29 E+01$ & $<3.17 E+01$ & & $<3.17 E+01$ & \\
\hline Mo & $<2.83 E+02$ & & $<3.05 E+02$ & $<2.94 E+02$ & & $<2.94 E+02$ & \\
\hline $\mathrm{Na}$ & $2.70 \mathrm{E}+05$ & $1 \mathrm{E}+03$ & $2.80 \mathrm{E}+05$ & $3.05 E+05$ & $2 \mathrm{E}+03$ & $2.96 \mathrm{E}+05$ & $3 E+03$ \\
\hline $\mathrm{Ni}$ & $<1.04 E+02$ & & $<1.12 E+02$ & $<1.08 E+02$ & & $<1.08 E+02$ & \\
\hline$P$ & $</=7.46 \mathrm{E}+02$ & & $8.45 E+02$ & $8.41 \mathrm{E}+02$ & $1.5 \mathrm{E}+01$ & $9.80 \mathrm{E}+02$ & $5.1 \mathrm{E}+01$ \\
\hline $\mathrm{Pb}$ & $<3.41 E+02$ & & $<3.68 E+02$ & $<3.55 E+02$ & & $<3.55 E+02$ & \\
\hline$S$ & $<5.30 E+02$ & & $<5.71 E+02$ & $<5.51 E+02$ & & $<5.51 E+02$ & \\
\hline $\mathrm{Sb}$ & $<2.10 E+02$ & & $<2.26 E+02$ & $<2.18 E+02$ & & $<2.18 E+02$ & \\
\hline $\mathrm{Si}$ & $<5.13 E+01$ & & $<5.53 E+01$ & $<5.34 E+01$ & & $<5.33 E+01$ & \\
\hline Sn & $<3.40 E+02$ & & $<3.66 E+02$ & $<3.54 E+02$ & & $<3.53 E+02$ & \\
\hline $\mathrm{Sr}$ & $<1.39 E+02$ & & $<1.49 E+02$ & $<1.44 E+02$ & & $<1.44 E+02$ & \\
\hline $\mathrm{Ti}$ & $<8.33 E+00$ & & $<8.97 E+00$ & $<8.66 E+00$ & & $<8.65 E+00$ & \\
\hline $\mathrm{V}$ & $<1.53 E+01$ & & $<1.64 E+01$ & $<1.59 E+01$ & & $<1.59 E+01$ & \\
\hline $\mathrm{Zn}$ & $<7.63 E+01$ & & $<8.22 E+01$ & $<7.94 E+01$ & & $<7.93 E+01$ & \\
\hline $\mathrm{Zr}$ & $<1.67 E+01$ & & $<1.79 E+01$ & $<1.73 E+01$ & & $<1.73 E+01$ & \\
\hline
\end{tabular}


WSRC-TR-2004-00131

Revision 0

Table 20: Tank 3F Free Liquid and Interstitial Liquid IC Anions, wet chemistry titration, and TIC/TOC results (mg/L)

\begin{tabular}{|c|c|c|c|c|c|c|c|}
\hline Sample: & \multicolumn{2}{|c|}{ T3F-1-1 FL } & T3F-1-3 FL & \multicolumn{2}{|c|}{ T3F-1-4 FL } & \multicolumn{2}{|c|}{ T3F-1-4 IL } \\
\hline$(\mathrm{mg} / \mathrm{L})$ & Average & St. Dev. & & Average & St. Dev. & Average & St. Dev. \\
\hline $\mathrm{NO}_{3}$ & $1.39 E+05$ & $5 \mathrm{E}+02$ & $1.15 E+05$ & 1.10E+05 & $1 \mathrm{E}+03$ & $1.06 \mathrm{E}+05$ & $5 \mathrm{E}+02$ \\
\hline $\mathrm{NO}_{2}$ & $1.33 E+05$ & $5 E+02$ & $1.11 \mathrm{E}+05$ & $1.06 \mathrm{E}+05$ & $5 E+02$ & $1.04 \mathrm{E}+05$ & $1 \mathrm{E}+03$ \\
\hline $\mathrm{SO}_{4}{ }^{2-}$ & $<3.81 E+03$ & & $<3.83 E+03$ & $<3.73 E+03$ & & $<3.58 E+03$ & \\
\hline $\mathrm{PO}_{4}{ }^{3-}$ & $<7.62 E+03$ & & $<7.66 E+03$ & $<7.46 E+03$ & & $<7.16 E+03$ & \\
\hline $\mathrm{Cl}^{-}$ & $1.18 \mathrm{E}+03$ & $5 E+01$ & $1.23 E+03$ & $<1.49 E+03$ & & $<1.43 E+03$ & \\
\hline $\mathrm{F}$ & $<1.52 E+03$ & & $<1.53 E+03$ & $<1.49 E+03$ & & $<1.43 E+03$ & \\
\hline $\mathrm{C}_{2} \mathrm{O}_{4}{ }^{2-}$ & $<7.62 E+03$ & & $<7.66 E+03$ & $<7.46 E+03$ & & $<7.16 E+03$ & \\
\hline $\mathrm{CHO}_{2}^{-}$ & $<7.62 E+03$ & & $<7.66 E+03$ & $<7.46 E+03$ & & $<7.16 E+03$ & \\
\hline Free $\mathrm{OH}^{-}$ & $1.21 \mathrm{E}+05$ & $1.1 \mathrm{E}+04$ & $1.22 \mathrm{E}+05$ & $1.05 E+05$ & $1.2 \mathrm{E}+04$ & $1.15 E+05$ & $2.0 \mathrm{E}+04$ \\
\hline $\mathrm{CO}_{3}{ }^{2-}$ & $<9.15 E+03$ & & $<9.20 E+03$ & $<8.96 E+03$ & & $<8.59 E+03$ & \\
\hline $\mathrm{CO}_{3}{ }^{2-}(\mathrm{TIC})$ & $4.24 \mathrm{E}+03$ & $1.87 E+03$ & $4.25 E+03$ & $5.28 \mathrm{E}+03$ & $1.3 \mathrm{E}+02$ & $5.17 E+03$ & $3.3 \mathrm{E}+02$ \\
\hline TOC & $4.78 E+03$ & $2.5 \mathrm{E}+02$ & $4.09 E+03$ & $4.38 \mathrm{E}+03$ & $6.4 \mathrm{E}+02$ & $3.62 E+03$ & $5 \mathrm{E}+01$ \\
\hline Tot. Base (M) & $7.36 \mathrm{E}+00$ & $1.2 \mathrm{E}-01$ & $8.89 \mathrm{E}+00$ & $6.17 \mathrm{E}+00$ & $1.1 \mathrm{E}-01$ & $8.55 \mathrm{E}+00$ & $5 \mathrm{E}-02$ \\
\hline $\mathrm{OH}^{-}$(calculated) & $1.15 \mathrm{E}+05$ & & $1.40 \mathrm{E}+05$ & $9.24 E+04$ & & $1.33 \mathrm{E}+05$ & \\
\hline
\end{tabular}

Table 21: Tank 3F Free Liquid and Interstitial Liquid rad. chem. results ( $\mathrm{pCi} / \mathrm{mL}$ )

\begin{tabular}{|c|rr|r|rrr|rr|}
\hline Sample: & \multicolumn{2}{|c|}{ T3F-1-1 FL } & T3F-1-3 FL & \multicolumn{2}{|c|}{ T3F-1-4 FL } & \multicolumn{2}{c|}{ T3F-1-4 IL } \\
\hline$(\mathrm{pCi} / \mathrm{mL})$ & Average & St. Dev. & & Average & St. Dev. & \multicolumn{2}{|c|}{ Average } & St. Dev. \\
\hline${ }^{14} \mathrm{C}$ & -- & & -- & -- & & $<2.2 \mathrm{E}+03$ & \\
\hline${ }^{90} \mathrm{Sr}$ & $4.20 \mathrm{E}+05$ & $2 \mathrm{E}+05$ & $8.72 \mathrm{E}+05$ & $5.04 \mathrm{E}+05$ & $6 \mathrm{E}+04$ & $4.50 \mathrm{E}+05$ & $6 \mathrm{E}+04$ \\
\hline${ }^{137} \mathrm{Cs}$ & $1.61 \mathrm{E}+09$ & $7 \mathrm{E}+07$ & $1.74 \mathrm{E}+09$ & $1.87 \mathrm{E}+09$ & $2 \mathrm{E}+07$ & $1.88 \mathrm{E}+09$ & $3 \mathrm{E}+07$ \\
\hline${ }^{238} \mathrm{Pu}$ & $1.12 \mathrm{E}+03$ & $4.9 \mathrm{E}+02$ & $3.47 \mathrm{E}+03$ & $1.48 \mathrm{E}+03$ & $7.5 \mathrm{E}+02$ & $6.72 \mathrm{E}+03$ & $4.1 \mathrm{E}+02$ \\
\hline${ }^{239 / 240} \mathrm{Pu}$ & $<8.56 \mathrm{E}+02$ & & $1.49 \mathrm{E}+03$ & $<9.82 \mathrm{E}+02$ & & $2.77 \mathrm{E}+03$ & $2.5 \mathrm{E}+02$ \\
\hline${ }^{241} \mathrm{Am}$ & $1.87 \mathrm{E}+03$ & $2 \mathrm{E}+02$ & $8.11 \mathrm{E}+03$ & $1.25 \mathrm{E}+03$ & -- & $1.96 \mathrm{E}+03$ & $9 \mathrm{E}+00$ \\
\hline Gross Alpha & $<2.00 \mathrm{E}+07$ & & $<5.25 \mathrm{E}+07$ & $<3.92 \mathrm{E}+06$ & & $<1.54 \mathrm{E}+07$ & \\
\hline Gross Beta & $1.88 \mathrm{E}+09$ & $4 \mathrm{E}+07$ & $1.89 \mathrm{E}+09$ & $2.18 \mathrm{E}+09$ & $2 \mathrm{E}+07$ & $2.15 \mathrm{E}+09$ & $6 \mathrm{E}+07$ \\
\hline
\end{tabular}


Table 22: Tank 3F Free Liquid and Interstitial Liquid ICP-MS results (mg/L)

\begin{tabular}{|c|c|c|c|c|c|c|c|}
\hline Sample: & \multicolumn{2}{|c|}{ T3F-1-1 FL } & T3F-1-3 FL & \multicolumn{2}{|c|}{ T3F-1-4 FL } & \multicolumn{2}{|c|}{ T3F-1-4 IL } \\
\hline$(\mathrm{mg} / \mathrm{L})$ & Average & St. Dev. & & Average & St. Dev. & Average & St. Dev. \\
\hline Mass 88 & $<7.46 E-02$ & -- & $<8.04 E-02$ & $<7.76 E-02$ & -- & $<7.75 E-02$ & -- \\
\hline Mass 99 & $1.84 \mathrm{E}+01$ & $1.12 \mathrm{E}+00$ & $1.83 E+01$ & $2.19 \mathrm{E}+01$ & $4.38 \mathrm{E}-02$ & $2.14 \mathrm{E}+01$ & $3.29 \mathrm{E}-01$ \\
\hline Mass 101 & $9.28 \mathrm{E}-01$ & 4.49E-02 & 8.23E-01 & 9.38E-01 & 5.47E-02 & 8.23E-01 & 7.14E-03 \\
\hline Mass 129 & $<7.15 E-01$ & -- & $<7.70 E-01$ & $<7.43 E-01$ & -- & $<7.42 E-01$ & -- \\
\hline Mass 133 & $4.61 \mathrm{E}+01$ & $3.03 E+00$ & $4.63 \mathrm{E}+01$ & $5.42 \mathrm{E}+01$ & 4.91E-02 & $5.33 E+01$ & $9.58 \mathrm{E}-01$ \\
\hline Mass 135 & $5.41 \mathrm{E}+00$ & 2.05E-01 & $5.41 \mathrm{E}+00$ & $6.57 \mathrm{E}+00$ & 5.69E-02 & $6.47 \mathrm{E}+00$ & 7.06E-02 \\
\hline Mass 137 & $2.18 \mathrm{E}+01$ & $1.24 \mathrm{E}+00$ & $2.32 \mathrm{E}+01$ & $2.81 \mathrm{E}+01$ & $5.75 \mathrm{E}-01$ & $2.63 E+01$ & $2.80 \mathrm{E}-01$ \\
\hline Mass 138 & $9.58 \mathrm{E}-01$ & $1.06 \mathrm{E}+00$ & 2.34E-01 & 1.36E-01 & 1.66E-02 & $3.00 \mathrm{E}-01$ & 4.77E-02 \\
\hline Mass 230 & $<1.45 E-01$ & -- & $<1.56 E-01$ & $<1.51 E-01$ & -- & $<1.51 E-01$ & -- \\
\hline Mass 231 & $<1.45 E-01$ & -- & $<1.56 E-01$ & $<1.51 E-01$ & -- & $<1.51 E-01$ & -- \\
\hline Mass 232 & $<1.45 E-01$ & -- & $<1.56 E-01$ & $<1.51 E-01$ & -- & $<1.51 E-01$ & -- \\
\hline Mass 233 & $<1.45 E-01$ & -- & $<1.56 E-01$ & $<1.51 E-01$ & -- & $<1.51 E-01$ & -- \\
\hline Mass 234 & $<1.45 E-01$ & -- & $<1.56 E-01$ & $<1.51 E-01$ & -- & $<1.51 E-01$ & -- \\
\hline Mass 235 & $<1.45 E-01$ & -- & $<1.56 E-01$ & $<1.51 E-01$ & -- & $<1.51 E-01$ & -- \\
\hline Mass 236 & $<1.45 E-01$ & -- & $<1.56 E-01$ & $<1.51 E-01$ & -- & $<1.51 E-01$ & -- \\
\hline Mass 237 & $<1.45 E-01$ & -- & $<1.56 E-01$ & $<1.51 E-01$ & -- & $<1.51 E-01$ & -- \\
\hline Mass 238 & $1.40 \mathrm{E}+00$ & $8.4 \mathrm{E}-01$ & $3.99 \mathrm{E}+00$ & 5.55E-01 & $2.65 \mathrm{E}-01$ & $2.19 \mathrm{E}+00$ & $4 \mathrm{E}-02$ \\
\hline Mass 239 & $<1.45 E-01$ & -- & $<1.56 E-01$ & $<1.51 E-01$ & -- & $<1.51 E-01$ & -- \\
\hline Mass 240 & $<1.45 E-01$ & -- & $<1.56 E-01$ & $<1.51 E-01$ & -- & $<1.51 E-01$ & -- \\
\hline Mass 241 & $<1.45 E-01$ & -- & $<1.56 E-01$ & $<1.51 E-01$ & -- & $<1.51 E-01$ & -- \\
\hline Mass 242 & $<1.45 E-01$ & -- & $<1.56 E-01$ & $<1.51 E-01$ & -- & $<1.51 E-01$ & -- \\
\hline Mass 243 & $<1.45 E-01$ & -- & $<1.56 E-01$ & $<1.51 E-01$ & -- & $<1.51 E-01$ & -- \\
\hline Mass 244 & $<1.45 E-01$ & -- & $<1.56 E-01$ & $<1.51 E-01$ & -- & $<1.51 E-01$ & -- \\
\hline
\end{tabular}


WSRC-TR-2004-00131

Revision 0

Table 23: Likely major components of Tank $3 F$ salt solids, normalized to $100 \mathrm{wt}$ \%

\begin{tabular}{|l|c|c|}
\hline \multicolumn{1}{|c|}{ (wt \%) } & T3F-1-1 & T3F-1-4 \\
\hline $\mathrm{NaNO}_{3}$ & 98.2 & 94.8 \\
\hline $\mathrm{Na}_{2} \mathrm{CO}_{3}{ }^{*} \mathrm{H}_{2} \mathrm{O}$ & 1.4 & 2.5 \\
\hline $\mathrm{NaNO}_{2}$ & 0.4 & 2.4 \\
\hline $\mathrm{NaAlO}_{2}{ }^{*} 2 \mathrm{H}_{2} \mathrm{O}$ & 0.0 & 0.2 \\
\hline
\end{tabular}

Table 24: Tank 2F Undrained Bulk Saltcake rad. chem. results (pCi/g)

\begin{tabular}{|c|rc|}
\hline Sample: & \multicolumn{2}{|c|}{ T2F-1-1 } \\
\hline (pCi/g) & Average & St. Dev. \\
\hline${ }^{14} \mathrm{C}$ & $1.8 \mathrm{E}+03$ & -- \\
\hline${ }^{90} \mathrm{Sr}$ & $1.3 \mathrm{E}+06$ & $2 \mathrm{E}+05$ \\
\hline${ }^{137} \mathrm{Cs}$ & $9.70 \mathrm{E}+07$ & $2.7 \mathrm{E}+06$ \\
\hline${ }^{238} \mathrm{Pu}^{\mathrm{a}}$ & $1.08 \mathrm{E}+04$ & $3.8 \mathrm{E}+03$ \\
\hline${ }^{239 / 240} \mathrm{Pu}^{\mathrm{a}}$ & $6.47 \mathrm{E}+03$ & $1.09 \mathrm{E}+03$ \\
\hline${ }^{241} \mathrm{Am}^{\mathrm{a}}$ & $3.63 \mathrm{E}+03$ & $9.4 \mathrm{E}+02$ \\
\hline
\end{tabular}

Note a: The analytical blank prepared and processed along with the samples had $\mathrm{Pu}$ and $\mathrm{Am}$ contamination on the same order-of-magnitude as the sample results. Thus, the Pu and Am reported here are upper limits of the sample's $\mathrm{Pu}$ and Am activity. 
Table 25: Tank 2F Undrained Bulk Saltcake ICP-ES results (g/100g)

\begin{tabular}{|c|c|c|}
\hline Sample: & \multicolumn{2}{|c|}{ T2F-1-1 } \\
\hline$(g / 100 g)$ & Average & St. Dev. \\
\hline $\mathrm{Ag}$ & $<7.44 E-04$ & -- \\
\hline $\mathrm{Al}$ & $1.43 E+00$ & $2.1 \mathrm{E}-01$ \\
\hline B & $<8.03 E-02$ & -- \\
\hline $\mathrm{Ba}$ & 2.64E-03 & 3.2E-04 \\
\hline $\mathrm{Ca}$ & $<2.25 E-02$ & - \\
\hline $\mathrm{Cd}$ & $<9.92 E-04$ & - \\
\hline $\mathrm{Ce}$ & $<1.23 E-02$ & -- \\
\hline $\mathrm{Cr}$ & 9.93E-03 & 9.7E-04 \\
\hline $\mathrm{Cu}$ & $<1.54 E-03$ & -- \\
\hline $\mathrm{Fe}$ & $1.52 \mathrm{E}-01$ & $2.0 \mathrm{E}-02$ \\
\hline $\mathrm{Gd}$ & $<1.34 E-03$ & -- \\
\hline $\mathrm{K}$ & $<4.72 E-01$ & -- \\
\hline $\mathrm{La}$ & $<9.92 E-04$ & -- \\
\hline$\overline{\mathrm{Li}}$ & $<4.21 E-03$ & -- \\
\hline $\mathrm{Mg}$ & $</=3.6 E-03$ & 9E-04 \\
\hline $\mathrm{Mn}$ & $3.15 \mathrm{E}-03$ & $1.21 \mathrm{E}-03$ \\
\hline Mo & $<1.01 E-02$ & -- \\
\hline $\mathrm{Na}$ & $2.53 E+01$ & $2 \mathrm{E}-01$ \\
\hline $\mathrm{Ni}$ & $<3.72 E-03$ & -- \\
\hline$P$ & $</=2.7 E-02$ & $5 \mathrm{E}-03$ \\
\hline $\mathrm{Pb}$ & $<1.22 E-02$ & -- \\
\hline$S$ & $1.86 \mathrm{E}-01$ & $4.2 \mathrm{E}-02$ \\
\hline $\mathrm{Sb}$ & $<7.49 E-03$ & -- \\
\hline$S i^{a}$ & 7.1E-03 & $4.2 \mathrm{E}-03$ \\
\hline Sn & $<1.21 E-02$ & - \\
\hline $\mathrm{Sr}$ & $<4.96 E-03$ & -- \\
\hline $\mathrm{Ti}$ & $<2.97 E-04$ & - \\
\hline $\mathrm{Zn}$ & $<2.73 E-03$ & - \\
\hline $\mathrm{Zr}$ & $<5.95 E-04$ & -- \\
\hline
\end{tabular}

Note a: Si for this set of samples is biased 25 to $30 \%$ high. 
WSRC-TR-2004-00131

Revision 0

Table 26: Tank 2F Undrained Bulk Saltcake AA results (g/100g)

\begin{tabular}{|c|cc|}
\hline Sample: & \multicolumn{2}{|c|}{ T2F-1-1 } \\
\hline (g/100g) & Average & St. Dev. \\
\hline As & $<2.5 E-04$ & -- \\
\hline $\mathrm{K}$ & $4.9 \mathrm{E}-02$ & $1 \mathrm{E}-03$ \\
\hline $\mathrm{Se}$ & $<2.5 E-04$ & -- \\
\hline $\mathrm{Hg}$ & $<1.8 E-02$ & -- \\
\hline
\end{tabular}

Table 27: Tank 2F Undrained Bulk Saltcake ICP-MS results $(\mathrm{g} / \mathbf{1 0 0 g})$

\begin{tabular}{|c|c|c|}
\hline Sample: & \multicolumn{2}{|c|}{ T2F-1-1 } \\
\hline$(g / 100 g)$ & Average & St. Dev. \\
\hline Mass 59 & 6.0E-05 & $2.5 \mathrm{E}-05$ \\
\hline Mass 88 & 2.3E-05 & $1.2 \mathrm{E}-05$ \\
\hline Mass 99 & $2.4 \mathrm{E}-04$ & $2 \mathrm{E}-05$ \\
\hline Mass 101 & 7.5E-05 & $4 \mathrm{E}-06$ \\
\hline Mass 133 & $3.08 \mathrm{E}-04$ & $7 E-06$ \\
\hline Mass 135 & 8.4E-05 & $2.2 \mathrm{E}-05$ \\
\hline Mass 137 & $3.2 \mathrm{E}-03$ & $2 E-04$ \\
\hline Mass 138 & $4.8 \mathrm{E}-04$ & $2.4 \mathrm{E}-04$ \\
\hline Mass 230 & $<7.5 E-07$ & -- \\
\hline Mass 231 & $<7.5 E-07$ & -- \\
\hline Mass 232 & 2.6E-05 & $1.1 \mathrm{E}-05$ \\
\hline Mass 233 & $<7.5 E-07$ & -- \\
\hline Mass 234 & $<7.5 E-07$ & -- \\
\hline Mass 235 & $1.2 \mathrm{E}-05$ & $2.0 \mathrm{E}-06$ \\
\hline Mass 236 & 2.7E-06 & $7.1 \mathrm{E}-07$ \\
\hline Mass 237 & $<7.5 E-07$ & -- \\
\hline Mass 238 & $2.1 \mathrm{E}-03$ & $3.9 \mathrm{E}-04$ \\
\hline Mass 239 & 8.6E-06 & $8.1 \mathrm{E}-07$ \\
\hline Mass 240 & 2.7E-06 & $3.9 \mathrm{E}-07$ \\
\hline Mass 241 & $</=8.3 \mathrm{E}-07$ & $1.3 \mathrm{E}-07$ \\
\hline Mass 242 & $<7.5 E-07$ & -- \\
\hline Mass 243 & $<7.5 E-07$ & -- \\
\hline Mass 244 & $<7.5 E-07$ & - \\
\hline
\end{tabular}


Table 28: Tank 2F Undrained Bulk Saltcake IC Anions, wet chemistry titration, and TIC/TOC results $(\mathrm{g} / 100 \mathrm{~g})$

\begin{tabular}{|c|c|c|}
\hline Sample: & \multicolumn{2}{|c|}{ T2F-1-1 } \\
\hline$(g / 100 g)$ & Average & St. Dev. \\
\hline $\mathrm{NO}_{3}{ }^{-}$ & $4.76 \mathrm{E}+01$ & $2.0 \mathrm{E}+00$ \\
\hline $\mathrm{NO}_{2}^{-}$ & $1.26 \mathrm{E}+00$ & $5 \mathrm{E}-02$ \\
\hline $\mathrm{SO}_{4}{ }^{2-}$ & 4.31E-01 & $2.2 \mathrm{E}-02$ \\
\hline $\mathrm{PO}_{4}{ }^{3-}$ & 4.01E-02 & 8.7E-03 \\
\hline $\mathrm{Cl}^{-}$ & $</=1.67 \mathrm{E}-02$ & $7.6 \mathrm{E}-03$ \\
\hline $\mathrm{F}^{-}$ & $<1.00 E-02$ & \\
\hline $\mathrm{C}_{2} \mathrm{O}_{4}{ }^{2-}$ & $6.85 E-02$ & 2.7E-03 \\
\hline $\mathrm{CHO}_{2}^{-}$ & $<5.01 E-02$ & \\
\hline Free $\mathrm{OH}^{-}$ & $2.62 E+00$ & $1.1 \mathrm{E}+00$ \\
\hline $\mathrm{CO}_{3}{ }^{2-}(\mathrm{TIC})$ & $1.40 \mathrm{E}+00$ & $6.5 \mathrm{E}-01$ \\
\hline TOC & $1.05 \mathrm{E}+00$ & 8.6E-01 \\
\hline
\end{tabular}

Table 29: Tank 2F Free Liquid rad. chem. results $(\mathrm{pCi} / \mathrm{mL})$

\begin{tabular}{|c|cc|ccc|cc|}
\hline Tank 2F & \multicolumn{2}{|c|}{ As Received } & \multicolumn{2}{c|}{$0.45-\mu \mathrm{m}$ Filtrate } & \multicolumn{2}{c|}{$0.1-\mu \mathrm{m}$ Filtrate } \\
\hline$(\mathrm{pCi} / \mathrm{mL})$ & Average & St. Dev. & Average & St. Dev. & Average & St. Dev. \\
\hline${ }^{14} \mathrm{C}$ & \multicolumn{2}{|c|}{--} & & $<1.22 \mathrm{E}+03$ & -- & - & \\
\hline${ }^{90} \mathrm{Sr}^{\mathrm{a}}$ & $5.10 \mathrm{E}+04$ & $1.51 \mathrm{E}+04$ & $7.40 \mathrm{E}+03$ & $5.26 \mathrm{E}+03$ & $3.74 \mathrm{E}+05$ & $3.8 \mathrm{E}+04$ \\
\hline${ }^{137} \mathrm{Cs}$ & $1.64 \mathrm{E}+09$ & $1 \mathrm{E}+07$ & $1.64 \mathrm{E}+09$ & $1 \mathrm{E}+07$ & $1.65 \mathrm{E}+09$ & $0 \mathrm{E}+00$ \\
\hline${ }^{238} \mathrm{Pu}$ & $<8.40 \mathrm{E}+02$ & -- & $<9.89 \mathrm{E}+02$ & -- & $<2.04 E+03$ & -- \\
\hline${ }^{239 / 240} \mathrm{Pu}$ & $<3.92 E+02$ & -- & $<6.92 E+02$ & -- & $<1.42 E+03$ & -- \\
\hline${ }^{241} \mathrm{Am}$ & $<6.84 E+02$ & -- & $<9.96 E+02$ & -- & $<6.17 E+02$ & -- \\
\hline
\end{tabular}

Note (a): There was a high degree of scatter in ${ }^{90} \mathrm{Sr}$, and an unexpected result of greatest ${ }^{90} \mathrm{Sr}$ in the $0.1-\mu \mathrm{m}$ filtrate. 
WSRC-TR-2004-00131

Revision 0

Table 30: Tank 2F Free Liquid IC anions, wet chemistry titration, and TIC/TOC results (mg/L)

\begin{tabular}{|c|cc|}
\hline Tank 2F & \multicolumn{2}{|c|}{$0.45-\mu \mathrm{m}$ Filtrate } \\
\hline$(\mathrm{mg} / \mathrm{L})$ & Average & St. Dev. \\
\hline $\mathrm{NO}_{3}{ }^{-}$ & $1.07 \mathrm{E}+05$ & $0 \mathrm{E}+00$ \\
\hline $\mathrm{NO}_{2}{ }^{-}$ & $1.15 \mathrm{E}+05$ & $2 \mathrm{E}+03$ \\
\hline $\mathrm{SO}_{4}{ }^{2-}$ & $5.12 \mathrm{E}+02$ & $0 \mathrm{E}+00$ \\
\hline $\mathrm{PO}_{4}{ }^{3-}$ & $5.04 \mathrm{E}+03$ & $0 \mathrm{E}+00$ \\
\hline $\mathrm{Cl}^{-}$ & $5.48 \mathrm{E}+02$ & $5.2 \mathrm{E}+01$ \\
\hline $\mathrm{F}^{-}$ & $<1.46 \mathrm{E}+02$ & -- \\
\hline $\mathrm{C}_{2} \mathrm{O}_{4}{ }^{2-}$ & $5.85 \mathrm{E}+01$ & $2.07 \mathrm{E}+01$ \\
\hline $\mathrm{CHO}_{2}{ }^{-}$ & $<7.31 \mathrm{E}+02$ & -- \\
\hline $\mathrm{Total} \mathrm{Base}(\mathrm{M})^{-}$ & $1.00 \mathrm{E}+01$ & $6.7 \mathrm{E}-01$ \\
\hline $\mathrm{Free} \mathrm{OH}^{-}$ & $1.17 \mathrm{E}+05$ & $5.0 \mathrm{E}+03$ \\
\hline $\mathrm{CO}_{3}{ }^{2-}(\mathrm{TIC})$ & $1.19 \mathrm{E}+04$ & $1.6 \mathrm{E}+03$ \\
\hline $\mathrm{TOC}^{-}$ & $3.04 \mathrm{E}+03$ & $2.1 \mathrm{E}+02$ \\
\hline
\end{tabular}

Table 31: Tank 2F Free Liquid AA results (mg/L)

\begin{tabular}{|c|cc|cc|cc|c|}
\hline Tank 2F & \multicolumn{2}{|c|}{ As Received } & \multicolumn{2}{c|}{$0.45-\mu \mathrm{m}$ Filtrate } & \multicolumn{2}{c|}{$0.1-\mu \mathrm{m}$ Filtrate } \\
\hline$(\mathrm{mg} / \mathrm{L})$ & Average & St. Dev. & Average & St. Dev. & Average & St. Dev. \\
\hline $\mathrm{As}$ & $<3.5 \mathrm{E}+00$ & -- & $<3.7 E+00$ & -- & $<2.9 E+00$ & -- \\
\hline $\mathrm{K}$ & $9.2 \mathrm{E}+03$ & $6 \mathrm{E}+02$ & $9.2 \mathrm{E}+03$ & $2 \mathrm{E}+02$ & $1.0 \mathrm{E}+04$ & $5 \mathrm{E}+02$ \\
\hline $\mathrm{Se}$ & $<3.5 E+00$ & -- & $<3.7 E+00$ & -- & $<2.9 E+00$ & -- \\
\hline $\mathrm{Hg}$ & $<7.8 E+00$ & -- & $<8.0 E+00$ & -- & $<6.3 E-01$ & - \\
\hline
\end{tabular}


Table 32: Tank 2F Free Liquid ICP-ES results (mg/L)

\begin{tabular}{|c|c|c|c|c|c|c|}
\hline Tank 2F & \multicolumn{2}{|c|}{ As Received } & \multicolumn{2}{|c|}{$0.45-\mu \mathrm{m}$ Filtrate } & \multicolumn{2}{|c|}{$0.1-\mu \mathrm{m}$ Filtrate } \\
\hline (mg/L) & Average & St. Dev. & Average & St. Dev. & Average & St. Dev. \\
\hline $\mathrm{Ag}$ & $<1.06 E+01$ & - & $<1.10 E+01$ & -- & $<8.74 E+00$ & $0.0 \mathrm{E}+00$ \\
\hline $\mathrm{Al}$ & $2.45 \mathrm{E}+04$ & $1.4 \mathrm{E}+04$ & $2.34 \mathrm{E}+04$ & $2.0 \mathrm{E}+03$ & $2.47 \mathrm{E}+04$ & $4.3 E+02$ \\
\hline B & $<1.15 E+03$ & -- & $<1.18 E+03$ & -- & $<9.43 E+02$ & -- \\
\hline $\mathrm{Ba}$ & $<1.06 E+01$ & -- & $<1.10 E+01$ & -- & $<8.74 E+00$ & -- \\
\hline $\mathrm{Ca}$ & $<3.20 E+02$ & -- & $<3.31 E+02$ & -- & $<2.63 E+02$ & -- \\
\hline $\mathrm{Cd}$ & $<1.42 E+01$ & -- & $<1.46 E+01$ & -- & $<1.17 E+01$ & -- \\
\hline $\mathrm{Ce}$ & $<1.76 E+02$ & -- & $<1.80 E+02$ & -- & $<1.44 E+02$ & -- \\
\hline $\mathrm{Cr}$ & $2.82 \mathrm{E}+02$ & $1.1 \mathrm{E}+02$ & $2.65 \mathrm{E}+02$ & $2.4 \mathrm{E}+01$ & $2.76 \mathrm{E}+02$ & $9.6 \mathrm{E}+00$ \\
\hline $\mathrm{Cu}$ & $<2.20 E+01$ & -- & $<2.26 E+01$ & -- & $<1.80 E+01$ & -- \\
\hline $\mathrm{Fe}$ & $2.71 \mathrm{E}+01$ & $5.7 E+00$ & $<1.61 E+01$ & -- & $2.60 \mathrm{E}+01$ & $1 \mathrm{E}+00$ \\
\hline $\mathrm{Gd}$ & $<1.91 E+01$ & -- & $<1.97 E+01$ & -- & $<1.58 E+01$ & -- \\
\hline $\mathrm{K}$ & $9.78 \mathrm{E}+03$ & $1.4 \mathrm{E}+02$ & 1.07E+04 & $2.9 \mathrm{E}+02$ & $1.09 \mathrm{E}+04$ & 4.7E+02 \\
\hline $\mathrm{La}$ & $<1.42 E+01$ & -- & $<1.46 E+01$ & -- & $<1.17 E+01$ & -- \\
\hline $\mathrm{Li}$ & $<6.02 E+01$ & -- & $<6.21 E+01$ & -- & $<4.95 E+01$ & -- \\
\hline $\mathrm{Mg}$ & $<4.39 E+01$ & -- & $<4.53 E+01$ & -- & $<3.61 E+01$ & -- \\
\hline $\mathrm{Mn}$ & $<1.56 E+01$ & -- & $<1.61 E+01$ & -- & $<1.28 E+01$ & -- \\
\hline Mo & $1.90 \mathrm{E}+02$ & $1.4 \mathrm{E}+01$ & $<1.74 E+02$ & $3.6 \mathrm{E}+01$ & $1.84 \mathrm{E}+02$ & 1.7E+01 \\
\hline $\mathrm{Na}$ & $2.79 \mathrm{E}+05$ & $3.3 E+04$ & $2.77 \mathrm{E}+05$ & $2.1 \mathrm{E}+03$ & $2.84 \mathrm{E}+05$ & $0 \mathrm{E}+00$ \\
\hline $\mathrm{Ni}$ & $<5.31 E+01$ & -- & $<5.48 E+01$ & -- & $<4.36 E+01$ & -- \\
\hline $\mathrm{P}$ & $1.78 \mathrm{E}+03$ & $1 \mathrm{E}+01$ & $1.50 \mathrm{E}+03$ & $1.1 \mathrm{E}+02$ & $1.58 \mathrm{E}+03$ & $4 \mathrm{E}+01$ \\
\hline $\mathrm{Pb}$ & $<1.74 E+02$ & -- & $<1.79 E+02$ & -- & $<1.43 E+02$ & -- \\
\hline$S$ & $4.12 \mathrm{E}+02$ & $4.3 \mathrm{E}+01$ & $</=3.64 E+02$ & $1.2 \mathrm{E}+02$ & $3.57 \mathrm{E}+02$ & $7.4 \mathrm{E}+00$ \\
\hline $\mathrm{Sb}$ & $<1.07 E+02$ & -- & $<1.10 E+02$ & -- & $9.44 \mathrm{E}+01$ & $1.8 \mathrm{E}+00$ \\
\hline $\mathrm{Si}$ & $3.08 \mathrm{E}+02$ & $3.4 \mathrm{E}+01$ & $6.87 \mathrm{E}+02$ & $6.7 \mathrm{E}+01$ & $3.56 \mathrm{E}+02$ & $1.6 \mathrm{E}+01$ \\
\hline Sn & $<1.73 E+02$ & -- & $<1.79 E+02$ & -- & $<1.43 E+02$ & -- \\
\hline $\mathrm{Sr}$ & $<7.08 E+01$ & -- & $<7.30 E+01$ & -- & $<5.82 E+01$ & -- \\
\hline $\mathrm{Ti}$ & $<4.24 E+00$ & -- & $<4.38 E+00$ & -- & $<3.49 E+00$ & -- \\
\hline V & $</=8.02 E+00$ & $3.2 \mathrm{E}-01$ & $<8.03 E+00$ & -- & $<6.41 E+00$ & -- \\
\hline $\mathrm{Zn}$ & $<3.90 E+01$ & -- & $<4.02 E+01$ & -- & $<3.20 E+01$ & -- \\
\hline $\mathrm{Zr}$ & $<8.50 E+00$ & -- & $<8.77 E+00$ & -- & $<6.99 E+00$ & -- \\
\hline
\end{tabular}


Table 33: Tank 2F Free Liquid ICP-MS results (mg/L)

\begin{tabular}{|c|c|c|c|c|c|c|}
\hline Tank 2F & \multicolumn{2}{|c|}{ As Received $^{a}$} & \multicolumn{2}{|c|}{$0.45-\mu \mathrm{m}$ Filtrate ${ }^{a}$} & \multicolumn{2}{|c|}{$0.1-\mu \mathrm{m}$ Filtrate $^{a}$} \\
\hline (mg/L) & Average & St. Dev. & Average & St. Dev. & Average & St. Dev. \\
\hline Mass 59 & $2.1 \mathrm{E}-01$ & 4E-02 & 2.0E-01 & 4E-02 & 3.0E-01 & 1.3E-01 \\
\hline Mass 88 & $<1.2 E-01$ & -- & $<1.2 E-01$ & -- & $<9.9 E-02$ & -- \\
\hline Mass 99 & $2.40 \mathrm{E}+01$ & $2 \mathrm{E}-01$ & $2.45 \mathrm{E}+01$ & $1.0 \mathrm{E}+00$ & $2.66 \mathrm{E}+01$ & 7E-01 \\
\hline Mass 101 & $1.4 \mathrm{E}+00$ & $5 E-02$ & $2.1 E+00$ & 1.1E+00 & $2.4 \mathrm{E}+00$ & $5 E-01$ \\
\hline Mass 133 & $4.90 \mathrm{E}+01$ & 1.1E+00 & $4.95 E+01$ & $6.1 \mathrm{E}-01$ & $5.07 E+01$ & 7.9E-01 \\
\hline Mass 135 & $6.7 E+00$ & $1 \mathrm{E}-01$ & $6.7 E+00$ & 2E-02 & $6.8 \mathrm{E}+00$ & $2 \mathrm{E}-01$ \\
\hline Mass 137 & $2.26 \mathrm{E}+01$ & 3.3E-02 & $2.30 E+01$ & $4.3 E+00$ & $2.70 E+01$ & $1.9 \mathrm{E}+00$ \\
\hline Mass 138 & $5.4 \mathrm{E}-01$ & $6 \mathrm{E}-03$ & $6.0 \mathrm{E}-01$ & $2.8 \mathrm{E}-01$ & $4.2 \mathrm{E}-01$ & $7 \mathrm{E}-02$ \\
\hline Mass 230 & $<4.9 E-02$ & -- & $<5.0 E-02$ & -- & $<4.0 E-02$ & -- \\
\hline Mass 231 & $<4.9 E-02$ & -- & $<5.0 E-02$ & -- & $<4.0 E-02$ & -- \\
\hline Mass 232 & $<4.9 E-02$ & -- & $<5.0 E-02$ & -- & 7.3E-02 & $3.1 \mathrm{E}-02$ \\
\hline Mass 233 & $<4.9 E-02$ & -- & $<5.0 E-02$ & -- & $<4.0 E-02$ & -- \\
\hline Mass 234 & $<4.9 E-02$ & -- & $<5.0 E-02$ & -- & $<4.0 E-02$ & -- \\
\hline Mass 235 & $<4.9 E-02$ & -- & $<5.0 E-02$ & -- & 5.1E-02 & $8 E-03$ \\
\hline Mass 236 & $<4.9 E-02$ & -- & $<5.0 E-02$ & -- & $<4.0 E-02$ & -- \\
\hline Mass 237 & $<4.9 E-02$ & -- & $<5.0 E-02$ & -- & $<4.0 E-02$ & -- \\
\hline Mass 238 & 9.97E-01 & 7.7E-02 & $1.05 E+00$ & 1.7E-02 & $6.29 \mathrm{E}+00$ & 2.2E-01 \\
\hline Mass 239 & $<4.9 E-02$ & -- & $<5.0 E-02$ & -- & 5.6E-02 & 1.7E-02 \\
\hline Mass 240 & $<4.9 E-02$ & -- & $<5.0 E-02$ & -- & $<4.0 E-02$ & -- \\
\hline Mass 241 & $<4.9 E-02$ & -- & $<5.0 E-02$ & -- & $<4.0 E-02$ & -- \\
\hline Mass 242 & $<4.9 E-02$ & -- & $<5.0 E-02$ & -- & $<4.0 E-02$ & -- \\
\hline Mass 243 & $<4.9 E-02$ & -- & $<5.0 E-02$ & -- & $<4.0 E-02$ & -- \\
\hline Mass 244 & $<4.9 E-02$ & -- & $<5.0 E-02$ & -- & $<4.0 E-02$ & -- \\
\hline
\end{tabular}

Note a: Unexpectedly, the $0.1-\mu \mathrm{m}$ filtrate had the greatest amounts of ${ }^{238} \mathrm{U},{ }^{235} \mathrm{U},{ }^{239} \mathrm{Pu}$, and ${ }^{232} \mathrm{Th}$. 
Table 34: Likely major components of Tank $2 \mathrm{~F}$ salt solids, normalized to $100 \mathrm{wt} \%$

\begin{tabular}{|l|c|}
\hline Tank 2F & (wt \%) \\
\hline $\mathrm{NaNO}_{3}$ & 87.9 \\
\hline $\mathrm{NaAlO}_{2}{ }^{*} 2 \mathrm{H}_{2} \mathrm{O}$ & 7.4 \\
\hline $\mathrm{Na}_{2} \mathrm{CO}_{3}{ }^{*} \mathrm{H}_{2} \mathrm{O}$ & 3.7 \\
\hline $\mathrm{Na}_{2} \mathrm{SO}_{4}$ & 0.9 \\
\hline $\mathrm{Na}_{2} \mathrm{C}_{2} \mathrm{O}_{4}$ & 0.1 \\
\hline
\end{tabular}

Table 35. Input and results for Monte Carlo analysis of porosity and saturation estimates.

\begin{tabular}{lll}
\hline \hline \multicolumn{1}{c}{ Property } & \multicolumn{1}{c}{ T2F Parameters } & \multicolumn{1}{c}{ T3F Parameters } \\
\hline $\begin{array}{l}\text { Specific gravity } \\
\text { of interstitial } \\
\text { liquid }\end{array}$ & $\begin{array}{l}\text { Normal distribution } \\
\text { Mean }=1.5\end{array}$ & 1.49 \\
Std. Dev. $=0.03$ & \\
Weight \% water & Normal distribution & Normal distribution \\
& Mean $=0.062$ & Mean $=0.051$ \\
& Std. Dev. $=0.006$ & Std. Dev. $=0.026$ \\
\hline Specific gravity & Weibull distribution & Weibull distribution \\
of solids & Location $=2.26$ & Location $=2.26$ \\
& Scale $=0.05$ & Scale $=0.05$ \\
& Shape $=1.8$ & Shape $=1.8$ \\
\hline Mass fraction of & Normal distribution & Normal distribution \\
water in & Mean $=0.48$ & Mean $=0.50$ \\
interstitial liquid & Std. Dev. $=0.01$ & Std. Dev. $=0.01$ \\
\hline \multirow{3}{*}{ Results } & & \\
\hline Porosity & Log normal & Normal distribution \\
& distribution & Mean $=0.19$ \\
& Mean $=0.23$ & Std. Dev. $=0.05$ \\
& Std. Dev. $=0.01$ & \\
\hline Saturation & Normal distribution & Normal distribution \\
& Mean $=0.77$ & Mean $=0.77$ \\
& Std. Dev. $=0.06$ & Std. Dev. $=0.06$ \\
\hline
\end{tabular}


WSRC-TR-2004-00131

Revision 0

(a)

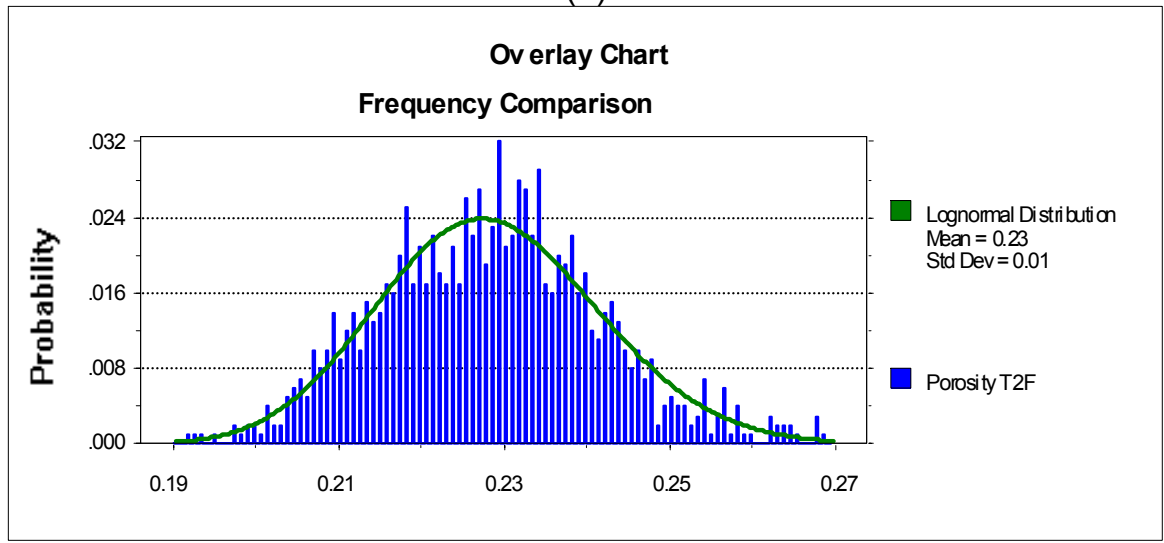

(b)

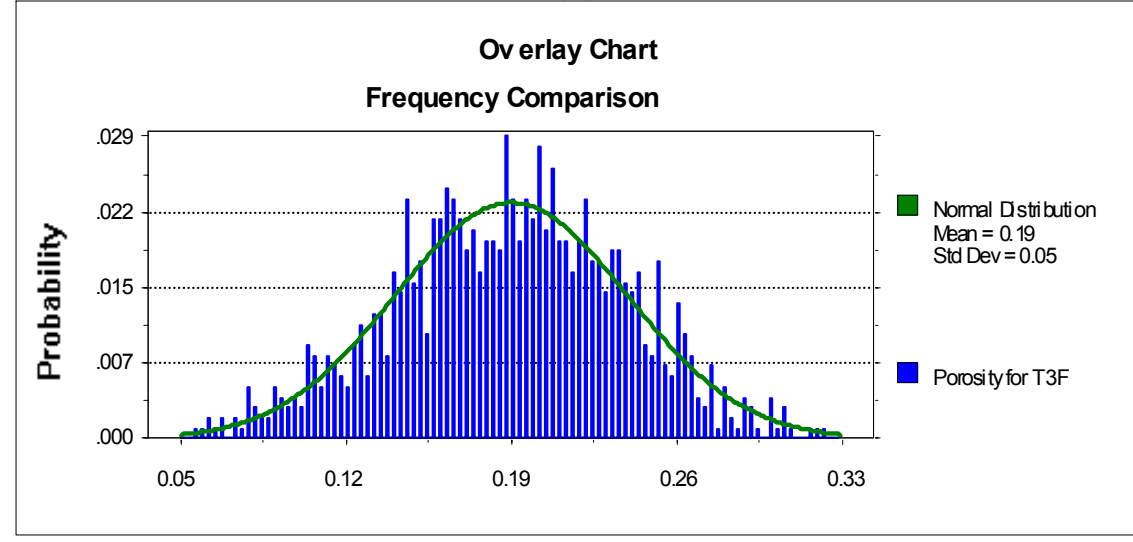

Figure 34 Variability of porosity estimate based on uncertainty of estimates for input parameters, (a) T2F, (b) T3F. 
Table 36: Dissolution information and Radioisotopic and lonic Analysis of the Dissolution of Drained T3F-1-4

\begin{tabular}{|c|c|c|c|c|c|c|c|c|}
\hline Sample T3F-1-4 & $1^{\text {st }}$ & $2^{\text {nd }}$ & $3^{\text {rd }}$ & $4^{\text {th }}$ & $5^{\text {th }}$ & $6^{\text {th }}$ & \multicolumn{2}{|l|}{ Bulk } \\
\hline Time (min) & 1.5 to 5.0 & 6.0 to 6.6 & 7.0 to 7.7 & 10.0 to 10.7 & 19.0 to 19.8 & 23.0 to 23.8 & \multicolumn{2}{|c|}{1.5 to 23.8} \\
\hline Flow Rate (mL/min) & 1.4 & 9.3 & 8.3 & 8.0 & 7.6 & 6.8 & \multicolumn{2}{|l|}{--} \\
\hline Volume (mL) & 0.0 to 4.9 & 14.9 to 20.8 & 30.8 to 36.2 & 56.2 to 62.1 & 122 to 128 & 148 to 153 & \multicolumn{2}{|c|}{0 to 153} \\
\hline Density $(\mathrm{g} / \mathrm{mL})$ & 1.45 & 1.34 & 1.33 & 1.28 & 1.00 & 1.00 & \multicolumn{2}{|l|}{1.19} \\
\hline \multicolumn{7}{|c|}{ Radioisotopic Composition (pCi/mL) } & avg. & st.dev. \\
\hline${ }^{90} \mathrm{Sr}$ & -- & -- & -- & -- & -- & -- & $2.37 \mathrm{E}+05$ & $3.9 E+04$ \\
\hline${ }^{99} \mathrm{Tc}$ minimum & -- & -- & -- & -- & -- & -- & $2.88 \mathrm{E}+05$ & $6 \mathrm{E}+02$ \\
\hline${ }^{99} \mathrm{Tc}$ maximum & -- & - & - & -- & -- & -- & $3.37 \mathrm{E}+05$ & $2 \mathrm{E}+03$ \\
\hline${ }^{137} \mathrm{Cs}$ & $4.06 \mathrm{E}+08$ & $7.55 \mathrm{E}+07$ & $3.41 \mathrm{E}+07$ & $1.68 \mathrm{E}+07$ & 1.47E+06 & -- & $3.29 \mathrm{E}+07$ & $2 \mathrm{E}+05$ \\
\hline${ }^{238} \mathrm{Pu}$ & $3.40 \mathrm{E}+03$ & $1.01 \mathrm{E}+03$ & $8.95 \mathrm{E}+02$ & $1.42 \mathrm{E}+02$ & $1.61 \mathrm{E}+02$ & -- & $7.18 \mathrm{E}+03$ & $4.68 \mathrm{E}+03$ \\
\hline${ }^{239 / 240} \mathrm{Pu}$ & $1.11 \mathrm{E}+03$ & $7.21 \mathrm{E}+02$ & $2.97 \mathrm{E}+02$ & $3.84 \mathrm{E}+02$ & $1.10 \mathrm{E}+02$ & -- & $2.33 E+03$ & $1.36 \mathrm{E}+03$ \\
\hline${ }^{241} \mathrm{Am}$ & $9.21 \mathrm{E}+02$ & $2.03 E+03$ & $7.00 \mathrm{E}+02$ & $8.18 \mathrm{E}+02$ & $4.39 \mathrm{E}+02$ & -- & $1.70 \mathrm{E}+03$ & $4.0 \mathrm{E}+02$ \\
\hline \multicolumn{7}{|c|}{ Ionic Composition (M) } & avg. & st.dev. \\
\hline $\mathrm{Na}^{+}$ & $1.02 \mathrm{E}+01$ & $7.15 \mathrm{E}+00$ & $6.55 \mathrm{E}+00$ & $5.53 \mathrm{E}+00$ & $2.24 \mathrm{E}-01$ & - & $3.28 \mathrm{E}+00$ & 2.0E-01 \\
\hline $\mathrm{NO}_{3}{ }^{-}$ & $4.38 \mathrm{E}+00$ & $4.90 \mathrm{E}+00$ & $5.05 E+00$ & $4.79 \mathrm{E}+00$ & $2.29 \mathrm{E}-01$ & -- & $2.61 \mathrm{E}+00$ & $3 E-02$ \\
\hline $\mathrm{NO}_{2}$ & $3.36 \mathrm{E}+00$ & $1.03 E+00$ & $6.02 \mathrm{E}-01$ & $1.68 \mathrm{E}-01$ & 8.16E-03 & -- & 3.73E-01 & 4E-03 \\
\hline $\mathrm{OH}^{-}$ & $9.16 \mathrm{E}-01$ & 3.69E-01 & $2.55 \mathrm{E}-01$ & $1.14 \mathrm{E}-01$ & 8.34E-02 & -- & $<5.16 E-02$ & - \\
\hline $\mathrm{AlO}_{2}{ }^{-}$ & 1.85E-01 & 3.57E-02 & 1.67E-02 & 9.75E-03 & 7.91E-04 & -- & 1.64E-02 & 7E-05 \\
\hline $\mathrm{CO}_{3}{ }^{2-}$ & $2.00 \mathrm{E}-01$ & $1.42 \mathrm{E}-01$ & $1.86 \mathrm{E}-01$ & $1.46 \mathrm{E}-01$ & $6.56 \mathrm{E}-02$ & -- & $2.75 \mathrm{E}-01$ & $2.0 \mathrm{E}-02$ \\
\hline $\mathrm{SO}_{4}{ }^{2-}$ & $6.72 \mathrm{E}-02$ & 8.30E-02 & $7.62 \mathrm{E}-02$ & 7.06E-02 & $2.60 \mathrm{E}-03$ & -- & 3.57E-02 & 4E-04 \\
\hline $\mathrm{PO}_{4}{ }^{3-}$ & $2.99 \mathrm{E}-03$ & $<6.41 E-03$ & $<6.07 E-03$ & $<6.00 E-03$ & $<4.39 E-03$ & -- & $<2.72 E-03$ & -- \\
\hline $\mathrm{Cl}^{-}$ & $<4.00 E-03$ & $<3.43 E-03$ & $<3.25 E-03$ & $<3.21 E-03$ & $<2.35 E-03$ & -- & $2.55 \mathrm{E}-04$ & 5.1E-05 \\
\hline $\mathrm{F}^{-}$ & $<7.47 E-03$ & $9.61 \mathrm{E}-03$ & $9.10 \mathrm{E}-03$ & 8.99E-03 & $<4.39 E-03$ & -- & 4.76E-03 & 9.61E-04 \\
\hline $\mathrm{C}_{2} \mathrm{O}_{4}{ }^{2-}$ & $1.61 \mathrm{E}-03$ & 2.07E-03 & 1.97E-03 & 1.29E-03 & 9.47E-04 & -- & $<2.93 E-03$ & -- \\
\hline $\mathrm{CHO}_{2}^{-}$ & $<1.58 E-02$ & $<1.35 E-02$ & $<1.28 E-02$ & $<1.27 E-02$ & $<9.26 E-03$ & -- & $<5.74 E-03$ & -- \\
\hline Total Base & $2.54 \mathrm{E}+00$ & 6.33E-01 & 4.16E-01 & 2.37E-01 & 8.34E-02 & -- & $<5.16 E-02$ & -- \\
\hline $\mathrm{K}^{+}$ & $6.78 \mathrm{E}-02$ & $<1.65 E-02$ & $<1.59 E-02$ & $<1.50 E-02$ & $<9.81 E-03$ & -- & 5.98E-03 & 7E-05 \\
\hline
\end{tabular}


WSRC-TR-2004-00131

Revision 0

Table 37: Other Elemental Analysis of the Dissolution of Drained T3F-1-4

\begin{tabular}{|c|c|c|c|c|c|c|c|c|}
\hline Sample T3F-1-4 & $1^{\text {st }}$ & $2^{\text {nd }}$ & $3^{\text {rd }}$ & $4^{\text {th }}$ & $5^{\text {th }}$ & $6^{\text {th }}$ & \multicolumn{2}{|l|}{ Bulk } \\
\hline \multicolumn{7}{|c|}{ Other Elemental Composition (mg/L) } & avg. & st.dev. \\
\hline $\mathrm{Ag}$ & $<1.10 E+00$ & $<1.04 E+00$ & $1.19 \mathrm{E}+00$ & $<9.47 E-01$ & $<6.21 E-01$ & -- & $<4.32 E-01$ & -- \\
\hline As & -- & -- & -- & -- & -- & -- & $<1.27 E+00$ & -- \\
\hline $\mathrm{B}$ & $<1.15 E+02$ & $<1.09 E+02$ & $<1.06 E+02$ & $<9.92 E+01$ & $<6.50 E+01$ & -- & $<4.53 E+01$ & -- \\
\hline $\mathrm{Ba}$ & $1.55 \mathrm{E}+00$ & $<1.04 E+00$ & $<1.01 E+00$ & $<9.47 E-01$ & $<6.21 E-01$ & -- & $7.76 \mathrm{E}+00$ & $1.12 \mathrm{E}+00$ \\
\hline $\mathrm{Ca}$ & $<3.21 E+01$ & $<3.05 E+01$ & $<2.95 E+01$ & $<2.78 E+01$ & $<1.82 E+01$ & -- & $<1.27 E+01$ & -- \\
\hline $\mathrm{Cd}$ & $<1.42 E+00$ & $<1.35 E+00$ & $3.44 \mathrm{E}+00$ & $<1.23 E+00$ & $<8.04 E-01$ & -- & $1.08 \mathrm{E}+00$ & $2.7 \mathrm{E}-01$ \\
\hline $\mathrm{Ce}$ & $<1.76 E+01$ & $<1.67 E+01$ & $<1.62 E+01$ & $<1.52 E+01$ & $<9.97 E+00$ & -- & $<6.94 E+00$ & -- \\
\hline $\mathrm{Cr}$ & $6.45 \mathrm{E}+01$ & $1.63 \mathrm{E}+01$ & $8.48 \mathrm{E}+00$ & $4.18 \mathrm{E}+00$ & $<6.94 E-01$ & -- & $5.18 \mathrm{E}+00$ & $5.2 \mathrm{E}-01$ \\
\hline Cs & -- & -- & -- & -- & -- & -- & $1.38 \mathrm{E}+00$ & $4 \mathrm{E}-02$ \\
\hline $\mathrm{Cu}$ & $4.53 \mathrm{E}+01$ & $6.80 \mathrm{E}+00$ & $3.20 \mathrm{E}+00$ & $<1.89 E+00$ & $<1.24 E+00$ & -- & $2.93 E+00$ & $1.1 \mathrm{E}-01$ \\
\hline $\mathrm{Fe}$ & $1.20 \mathrm{E}+01$ & $1.53 \mathrm{E}+01$ & $8.78 \mathrm{E}+00$ & $5.07 E+00$ & $1.13 E+00$ & -- & $6.79 \mathrm{E}+01$ & $2.2 \mathrm{E}+00$ \\
\hline $\mathrm{Gd}$ & $<1.93 E+00$ & $<1.84 E+00$ & $<1.78 E+00$ & $<1.67 E+00$ & $<1.10 E+00$ & -- & $</=8.14 E-01$ & $7.2 \mathrm{E}-02$ \\
\hline $\mathrm{Hg}$ & -- & -- & -- & -- & -- & -- & $<2.80 E+00$ & -- \\
\hline $\mathrm{La}$ & $<1.42 E+00$ & $<1.35 E+00$ & $2.14 \mathrm{E}+00$ & $<1.23 E+00$ & $<8.04 E-01$ & -- & $</=7.50 E-01$ & $2.70 \mathrm{E}-01$ \\
\hline $\mathrm{Li}$ & $<6.06 E+00$ & $<5.76 E+00$ & $<5.57 E+00$ & $<5.24 E+00$ & $<3.43 E+00$ & -- & $</=2.40 E+00$ & $2 \mathrm{E}-02$ \\
\hline $\mathrm{Mg}$ & $<4.39 E+00$ & $<4.17 E+00$ & $<4.03 E+00$ & $<3.79 E+00$ & $<2.48 E+00$ & -- & $3.00 \mathrm{E}+00$ & $1.26 \mathrm{E}+00$ \\
\hline $\mathrm{Mn}$ & $<1.55 E+00$ & $<1.47 E+00$ & $<1.42 E+00$ & $<1.34 E+00$ & $<8.77 E-01$ & -- & $1.60 \mathrm{E}+00$ & $1.19 \mathrm{E}+00$ \\
\hline Mo & $4.67 \mathrm{E}+01$ & $<1.37 E+01$ & $<1.33 E+01$ & $<1.25 E+01$ & $<8.18 E+00$ & -- & $<5.70 E+00$ & -- \\
\hline $\mathrm{Ni}$ & $<5.35 E+00$ & $<5.09 E+00$ & $<4.92 E+00$ & $<4.63 E+00$ & $<3.03 E+00$ & -- & $<2.11 E+00$ & -- \\
\hline $\mathrm{P}$ & $2.69 \mathrm{E}+02$ & $5.92 \mathrm{E}+01$ & $<3.17 E+01$ & $<2.98 E+01$ & $<1.95 E+01$ & -- & $1.21 \mathrm{E}+02$ & $6 \mathrm{E}+00$ \\
\hline $\mathrm{Pb}$ & $<1.75 E+01$ & $<1.66 E+01$ & $<1.61 E+01$ & $<1.51 E+01$ & $<9.90 E+00$ & -- & $<6.89 E+00$ & -- \\
\hline$S$ & $2.54 \mathrm{E}+03$ & $3.43 \mathrm{E}+03$ & $3.05 \mathrm{E}+03$ & $2.64 \mathrm{E}+03$ & $9.86 \mathrm{E}+01$ & -- & $1.39 \mathrm{E}+03$ & $3 E+01$ \\
\hline $\mathrm{Sb}$ & $1.79 \mathrm{E}+01$ & $<1.02 E+01$ & $<9.85 E+00$ & $<9.25 E+00$ & $<6.06 E+00$ & -- & $<4.22 E+00$ & -- \\
\hline $\mathrm{Se}$ & -- & -- & -- & -- & -- & -- & $<1.27 E+00$ & -- \\
\hline $\mathrm{Si}$ & $2.07 \mathrm{E}+02$ & $8.83 \mathrm{E}+01$ & $6.88 \mathrm{E}+01$ & $4.86 \mathrm{E}+01$ & $8.15 \mathrm{E}+00$ & -- & $1.27 \mathrm{E}+01$ & $3 \mathrm{E}-01$ \\
\hline Sn & $<1.74 E+01$ & $<1.66 E+01$ & $<1.60 E+01$ & $<1.50 E+01$ & $<9.86 E+00$ & -- & $<6.87 E+00$ & -- \\
\hline $\mathrm{Sr}$ & $<7.09 E+00$ & $<6.74 E+00$ & $<6.52 E+00$ & $<6.13 E+00$ & $<4.02 E+00$ & -- & $<2.80 E+00$ & -- \\
\hline $\mathrm{Ti}$ & $<4.51 E-01$ & $<4.29 E-01$ & $<4.15 E-01$ & $<3.90 E-01$ & $<2.56 E-01$ & -- & $<1.78 E-01$ & -- \\
\hline $\mathrm{V}$ & $3.61 \mathrm{E}+00$ & $<7.36 E-01$ & $<7.12 E-01$ & $<6.69 E-01$ & $<4.38 E-01$ & -- & -- & -- \\
\hline $\mathrm{Zn}$ & $7.35 \mathrm{E}+01$ & $1.17 \mathrm{E}+01$ & $6.88 \mathrm{E}+00$ & $<3.40 E+00$ & $<2.23 E+00$ & -- & $8.09 \mathrm{E}+00$ & $1.37 \mathrm{E}+00$ \\
\hline $\mathrm{Zr}$ & $<8.38 E-01$ & $<7.97 E-01$ & 8.90E-01 & $<7.24 E-01$ & $<4.75 E-01$ & -- & $<3.31 E-01$ & -- \\
\hline
\end{tabular}


Table 38: ICP-MS Analysis of the Dissolution of Drained T3F-1-4 (Bulk Filtered)

\begin{tabular}{|c|c|c|}
\hline Tank 3F & \multicolumn{2}{|c|}{ T3F-1-4 Bulk Dissolution } \\
\hline (mg/L) & Average & St. Dev. \\
\hline Mass 59 & $2.55 \mathrm{E}-01$ & 1.1E-01 \\
\hline Mass 88 & $1.01 \mathrm{E}-01$ & $3.5 \mathrm{E}-02$ \\
\hline Mass 99 & $5.53 \mathrm{E}-01$ & $3 \mathrm{E}-03$ \\
\hline Mass 101 & 1.07E-01 & $5 \mathrm{E}-03$ \\
\hline Mass 133 & $1.09 E+00$ & 4E-02 \\
\hline Mass 135 & 7.08E-01 & $1.2 \mathrm{E}-01$ \\
\hline Mass 137 & $1.72 \mathrm{E}+00$ & 2.2E-01 \\
\hline Mass 138 & $5.83 E+00$ & $1.2 \mathrm{E}+00$ \\
\hline Mass $230-231$ & $<2.7 E-02$ & - \\
\hline Mass 232 & $1.45 \mathrm{E}-01$ & 1.07E-01 \\
\hline Mass $233-234$ & $<2.7 E-02$ & - \\
\hline Mass 235 & $3.66 \mathrm{E}-01$ & $1.34 \mathrm{E}-02$ \\
\hline Mass 236 & $</=2.9 \mathrm{E}-02$ & $3 \mathrm{E}-03$ \\
\hline Mass 237 & $<2.7 E-02$ & - \\
\hline Mass 238 & $5.94 \mathrm{E}+00$ & $2.9 \mathrm{E}+00$ \\
\hline Mass 239 & $2.77 \mathrm{E}-02$ & $1.1 \mathrm{E}-03$ \\
\hline Mass $240-244$ & $<2.7 E-02$ & -- \\
\hline
\end{tabular}

